University of Louisville

ThinkIR: The University of Louisville's Institutional Repository

Electronic Theses and Dissertations

$12-2017$

\title{
Factors associated with federal student loan default among borrowers in a statewide system of community and technical colleges.
}

Brittany Inge

University of Louisville

Follow this and additional works at: https://ir.library.louisville.edu/etd

Part of the Higher Education Commons

\section{Recommended Citation}

Inge, Brittany, "Factors associated with federal student loan default among borrowers in a statewide system of community and technical colleges." (2017). Electronic Theses and Dissertations. Paper 2864. https://doi.org/10.18297/etd/2864

This Doctoral Dissertation is brought to you for free and open access by ThinkIR: The University of Louisville's Institutional Repository. It has been accepted for inclusion in Electronic Theses and Dissertations by an authorized administrator of ThinkIR: The University of Louisville's Institutional Repository. This title appears here courtesy of the author, who has retained all other copyrights. For more information, please contact thinkir@louisville.edu. 
FACTORS ASSOCIATED WITH FEDERAL STUDENT LOAN DEFAULT AMONG

BORROWERS IN A STATEWIDE SYSTEM OF COMMUNITY AND TECHNICAL

COLLEGES

\author{
By \\ Brittany Inge \\ B.A., University of Louisville, 2010 \\ M.A., University of Louisville, 2012 \\ A Dissertation \\ Submitted to the Faculty of the \\ College of Education and Human Development of the University of Louisville \\ in Partial Fulfillment of the Requirements \\ for the Degree of

\begin{abstract}
Doctor of Philosophy
in Educational Leadership and Organizational Development
\end{abstract} \\ College of Education and Human Development \\ University of Louisville \\ Louisville, Kentucky
}

December 2017 

FACTORS ASSOCIATED WITH FEDERAL STUDENT LOAN DEFAULT AMONG BORROWERS IN A STATEWIDE SYSTEM OF COMMUNITY AND TECHNICAL

\title{
COLLEGES
}

\author{
By
}

Brittany Inge

B.A., University of Louisville, 2010

M.A., University of Louisville, 2012

A Dissertation Approved on

August 22, 2017

by the following Dissertation Committee:

Jacob Gross, Dissertation Chair

Jeffrey Sun, Committee Member

Casey George, Committee Member

Kate Snyder, Committee Member 


\section{DEDICATION}

This dissertation is dedicated to my younger brothers and sisters:

Andrew, Noah, Meghan, Breanna, Brandon, and Stephanie. 


\section{ACKNOWLEDGEMENTS}

This dissertation was made possible by many individuals who supported me throughout my doctoral program journey. I want to express my sincere appreciation for my mentor, Dr. Jacob Gross, who believed in me before I believed in myself. Without his persistent encouragement and reassurance, I may have never submitted a doctoral program application, let alone complete this dissertation. I am eternally grateful for his insight, expertise, and generosity. Thank you to my dissertation committee members: Dr. Casey George, Dr. Kate Snyder, and Dr. Jeffrey Sun. Their collective expertise and feedback greatly enhanced the quality of my research while their gracious and collaborative approach made the dissertation process a rewarding experience, and for that I am incredibly grateful. Thank you to the Kentucky Community and Technical College System (KCTCS) for granting me permission to conduct this research and for providing support along the way, specifically: Derek Ball, Doug Cleary, Alicia Crouch, and Angela Johnson. To Amanda, Carrie, Kimberly, and other fellow doctoral students: thank you for the countless coffee dates, study (or just chat) sessions, and memes; I am grateful for your friendship. Finally, thank you to my parents, Mike and Shana, for encouraging me to work hard and for instilling in me a perseverance that has served me well through this educational journey (and in life) and to my Inge-in-laws, who were my crew of cheerleaders. And to Grant - my partner, best friend, and favorite comedian: thank you for the endless supply of laughter, encouragement, and brain food (mostly LC pizza). I am forever grateful that I get to do life with you. 


\begin{abstract}
FACTORS ASSOCIATED WITH FEDERAL STUDENT LOAN DEFAULT AMONG BORROWERS IN A STATEWIDE SYSTEM OF COMMUNITY AND TECHNICAL COLLEGES

Brittany Inge
\end{abstract}

August 22, 2017

Community colleges serve as a gateway to higher education for millions of American college students. Open-door admission policies and federal student aid facilitate the access that two-year public institutions provide, particularly for students who are under-resourced or academically under-prepared for college. However, a substantial number of community college students who use federal student loans to pay for college ultimately fail to repay the loans, yielding negative consequences for borrowers, institutions, and taxpayers.

By employing a Hierarchical Generalized Linear Model (HGLM) this study investigates individual-level and institution-level factors associated with federal student loan default among borrowers who attended a two-year public institution in a statewide system of community and technical colleges. The study findings indicate that relative to institution-level variables, individual-level variables possess much more explanatory power in predicting student loan default. Among the eleven institution-level factors included in the HGLM, only two factors were significantly associated with student loan default in the final model: the proportion of students at the institution who are eligible for 
the income-based Pell Grant and the unemployment rate for the county in which the institution is situated. Among the individual-level factors, being eligible for the Pell grant, being male, being classified as financially independent, requiring a medium or high level of developmental math, and requiring a developmental reading course emerged as the strongest predictors of student loan default, while earning an Associate degree, earning a higher cumulative GPA while enrolled in college, and transferring to a fouryear institution prior to entering repayment were the strongest predictors of successful repayment.

This study emphasizes the need for a shift in policy pertaining to the use of cohort default rates in measuring and addressing student loan default. This issue is particularly relevant amid use of broad metrics to facilitate performance-based funding schemes in many states. Providing more attention to policy and practice that aims to reduce federal student loan default is central to the efficacy of the American federal student loan program, to the effectiveness of community colleges, and to the development of American workforce and economy. 


\section{TABLE OF CONTENTS}

PAGE

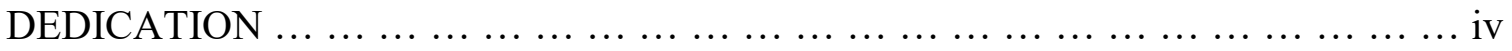

ACKNOWLEDGMENTS $\ldots \ldots \ldots \ldots \ldots \ldots \ldots \ldots \ldots \ldots \ldots \ldots \ldots \ldots \ldots \ldots$

ABSTRACT $\ldots \ldots \ldots \ldots \ldots \ldots \ldots \ldots \ldots \ldots \ldots \ldots \ldots \ldots \ldots \ldots \ldots \ldots \ldots \ldots \ldots \ldots$

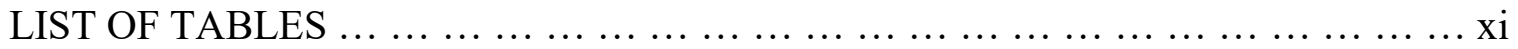

CHAPTER I: INTRODUCTION $\ldots \ldots \ldots \ldots \ldots \ldots \ldots \ldots \ldots \ldots \ldots \ldots \ldots \ldots \ldots \ldots$

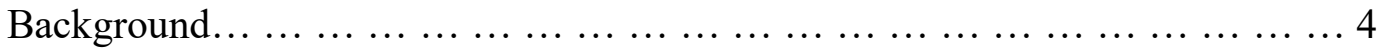

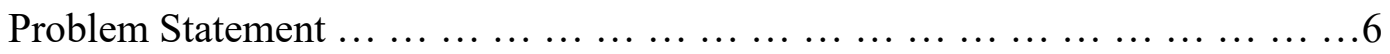

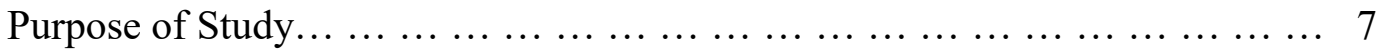

Research Questions $\ldots \ldots \ldots \ldots \ldots \ldots \ldots \ldots \ldots \ldots \ldots \ldots \ldots \ldots \ldots \ldots$

Definition of Terms $\ldots \ldots \ldots \ldots \ldots \ldots \ldots \ldots \ldots \ldots \ldots \ldots$

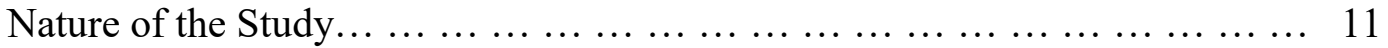

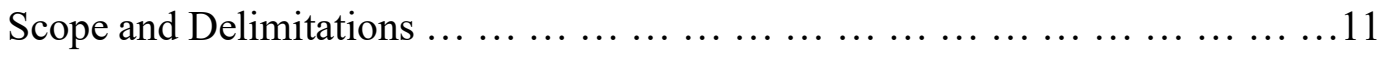

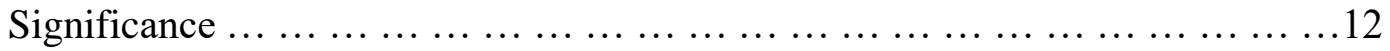

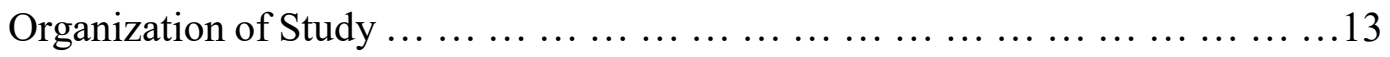

CHAPTER II: REVIEW OF LITERATURE $\ldots \ldots \ldots \ldots \ldots \ldots \ldots \ldots \ldots \ldots \ldots \ldots \ldots$

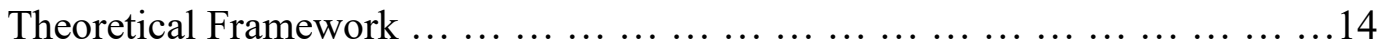

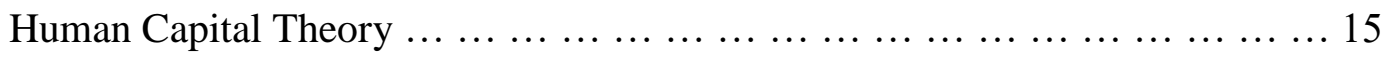

Cohort Default Rates: A Contextual Summary... .................... 20 
Factors Associated with Default on Student Loans... ... ... ... . . . . . ... 27

Individual-Level Factors... ... . . . . . . . . . . . . . . . . . . . . . . . . . . 14

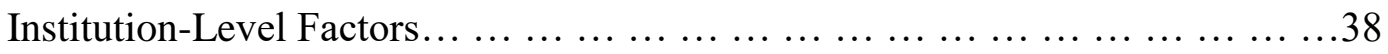

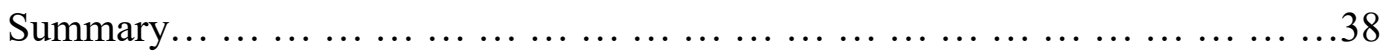

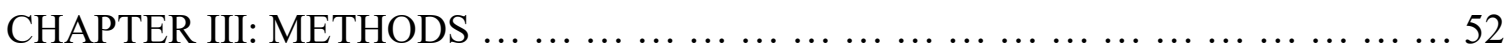

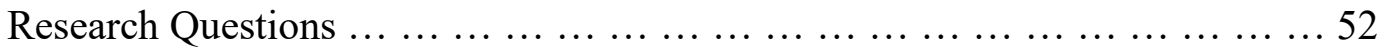

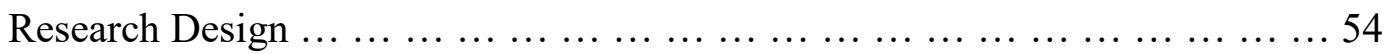

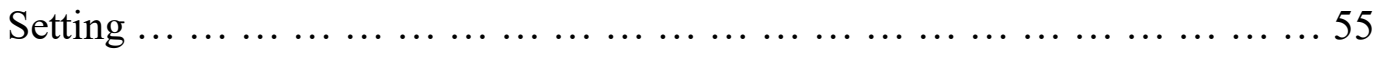

Population and Sample $\ldots \ldots \ldots \ldots \ldots \ldots \ldots \ldots \ldots \ldots \ldots \ldots \ldots$

Procedures $\ldots \ldots \ldots \ldots \ldots \ldots \ldots \ldots \ldots$

Operationalization of Study Variables... ........................662

Analytic Technique $\ldots \ldots \ldots \ldots \ldots \ldots \ldots \ldots \ldots \ldots \ldots \ldots \ldots \ldots \ldots \ldots \ldots$

Data Analysis... $\ldots \ldots \ldots \ldots \ldots \ldots$

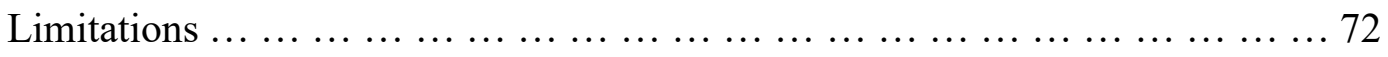

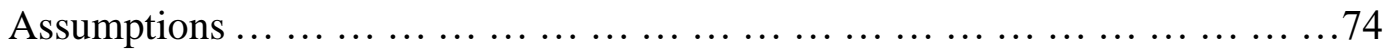

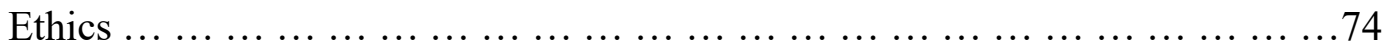

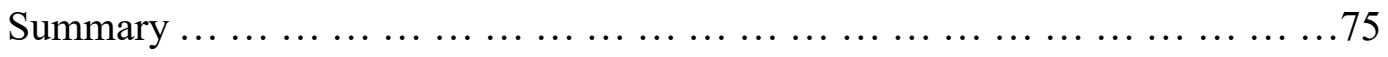

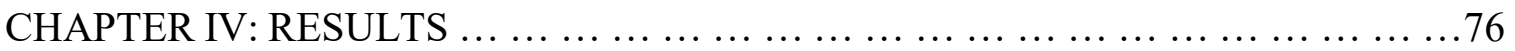

Sample Characteristics $\ldots \ldots \ldots \ldots \ldots \ldots \ldots \ldots \ldots \ldots \ldots \ldots \ldots \ldots \ldots$

Hierarchical Generalized Linear Model Results ... . . . . . . . . . . . . . . . 85

Individual-Level Explanatory Variable Findings $\ldots \ldots \ldots \ldots \ldots \ldots \ldots \ldots$

Institution-Level Explanatory Variable Findings ... . . . . . . . . . . . . . . . 94

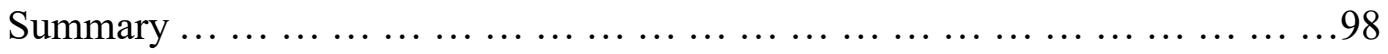


CHAPTER V: DISCUSSION $\ldots \ldots \ldots \ldots \ldots \ldots \ldots \ldots \ldots \ldots \ldots \ldots \ldots \ldots \ldots \ldots$

Key Findings $\ldots \ldots \ldots \ldots \ldots$

Theoretical Insight from Human Capital Theory... ... . . . . . . . . . . . . 106

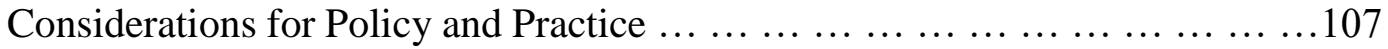

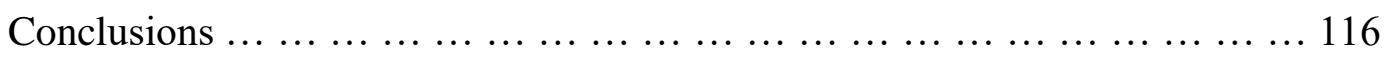

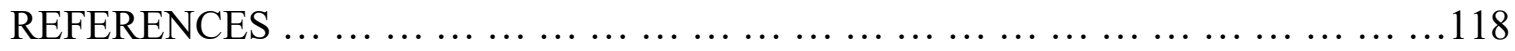

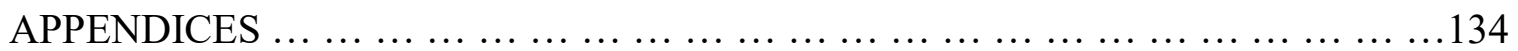

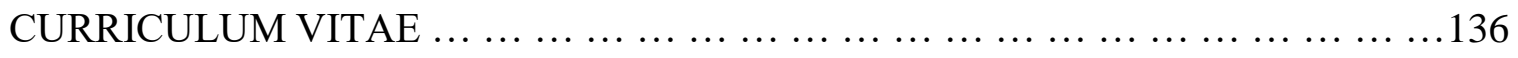




\section{LIST OF TABLES}

PAGE

1. Human Capital Theory and Student Loan Default $\ldots \ldots \ldots \ldots \ldots \ldots \ldots \ldots \ldots$

2. Two-Year Public Institutions in the State of Kentucky... ... . . . . . . . . . . . 57

3. Three-Year Cohort Default Rates Among KCTCS Institutions ... . . . . . . . . . 59

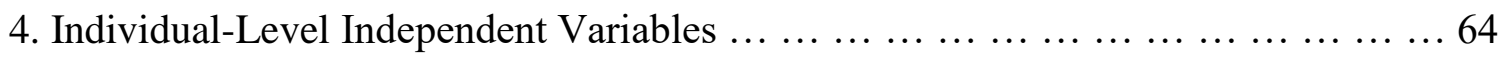

5. Institution-Level Independent Variables $\ldots \ldots \ldots \ldots \ldots \ldots \ldots \ldots \ldots \ldots \ldots \ldots \ldots \ldots \ldots \ldots$

6. Sample Characteristics: Demographic Variables... ... ... . . . . . . . . . . . . . 77

7. Sample Characteristics: College Readiness and Academic Variables ........... 78

8. Sample Characteristics: Financial Aid Variables... . . . . . . . . . . . . . . . . . 79

9. Sample Characteristics: Completion and Transfer Variables ... . . . . . . . . . . . ....79

10. Sample Characteristics: Student Loan Default Status $\ldots \ldots \ldots \ldots \ldots \ldots \ldots \ldots \ldots$

11. Descriptive Statistics by Default Status, Individual-Level Variables ... ....... 80

12. Descriptive Statistics by Default Status, Individual-Level Variables $\ldots \ldots \ldots \ldots \ldots 81$

13. Descriptive Statistics for Institutions, Institution-Level Variables $\ldots \ldots \ldots \ldots \ldots . \ldots 84$

14. HGLM Results: Unconditional Model $\ldots \ldots \ldots \ldots \ldots \ldots \ldots \ldots \ldots \ldots$

15. HGLM Results: Estimates of Level-One Coefficients and Odds Ratios ... . . . . . .89

16. HGLM Results: Estimates of Level-Two Coefficients and Odds Ratios ... ... ....95 


\section{CHAPTER I}

\section{INTRODUCTION}

Community colleges serve as a gateway to higher education for millions of American college students (American Association of Community Colleges, 2017). Open-door admission policies and federal student aid facilitate the access that two-year public institutions provide, particularly for students who are under-resourced or academically under-prepared for college. However, a substantial number of community college students who use federal student loans to pay for college ultimately fail to repay the loans: nationally, $18.5 \%$ of borrowers who attended a two-year public institution and entered repayment in cohort fiscal year (FY) 2013 defaulted on their student loans within three years (as compared to $7.3 \%$ of borrowers who attended a four-year public institution) (U.S. Department of Education, 2016a).

There are significant consequences associated with student loan default for borrowers, postsecondary institutions, and taxpayers. A student loan in default accrues interest and late fees and may significantly decrease a borrower's consumer credit score (U.S. Department of Education, 2016b). Borrowers may have their wages garnished if nonpayment on a defaulted loan persists (U.S. Department of Education, 2016b). The Department of Education calculates a cohort default rate (CDR) for every Title IV eligible postsecondary institution, which indicates the percent of borrowers who obtain a federal student loan and default within three years of entering repayment (U.S. 
Department of Education, 2016c). If a postsecondary institution's cohort default rate exceeds $30 \%$ for more than three consecutive years, the institution could be stripped of its eligibility to participate in Title IV programs (U.S. Department of Education, 2016c). The potential threat of Title IV eligibility loss prompted a few community colleges to voluntarily withdraw from the student loan component of the federal financial aid program in an effort to preserve access to federal Pell grant funding (McKinney, Gross, \& Burridge, 2014; Wiederspan, 2015). Considering the significant proportion of students who rely on student loans to pay for higher education expenses, Title IV eligibility loss (or voluntary withdrawal from the student loan program) poses a financial threat not only to a college or university, but to the broader community served by the postsecondary institution. There are additional consequences of default for the general public: as the guarantor of federal student loans, the U.S. government (and thus, taxpayers) eventually assumes the costs associated with unpaid student loan debt (U.S. Department of Education, 2016d).

The U.S. Department of Education advises postsecondary institutions to actively avert student loan default and recommends that postsecondary institutions develop a default management plan that addresses student loan default prevention from a holistic institutional perspective (U.S. Department of Education, 2016e). Many colleges and universities aim to reduce the proportion of borrowers who default through institutionwide programming efforts, such as financial literacy education and enhanced entrance and exit counseling procedures (Charles, Sheaff, Woods, \& Downey, 2016; Dillon \& Smiles, 2010; McKibben, La Rocque, \& Cochrane, 2014; McKinney, Gross, \& Burridge, 2014). However, considering the resource constraints facing most postsecondary 
institutions (in terms of finances, time, and personnel), to most effectively and efficiently reduce the prevalence of student loan default, colleges and universities must leverage resources towards borrowers at greatest risk of default (Kesterman, 2006; McKibben, La Rocque, \& Cochrane, 2014; McKinney, Gross, \& Burridge, 2014; U.S. Department of Education, 2016e). While there is a body of literature that examines borrower risk factors pertaining to student loan default, very few studies explore default in the context of community colleges and the population that public, open-access, two-year institutions serve. As discussed more thoroughly in the following pages, the scarcity in research that explores default among loan recipients who attended a community college renders a substantial gap in the body of scholarly knowledge pertaining to student loan default. This chasm leaves community college administrators with little research to elicit regarding how to design interventions that are effective in decreasing loan default rates in the two-year public sector. Scholarly and rigorous academic research is needed to help ascertain determinants of student loan default among borrowers from two-year public postsecondary institutions. This line of inquiry has the potential to support efforts to develop student loan default interventions that are resourceful, effective, and specific to loan recipients who attend community college.

Further, to most efficiently align resources to address student loan default from an institutional perspective, more understanding is needed regarding the factors associated with loan default and the degree to which these variables are (and are not) within the purview of postsecondary institutions. Currently, however, the degree to which institutions influence student loan default, particularly among institutions that serve a significant proportion of at-risk students, is a topic is largely underdeveloped in the 
academic literature. To address both of the aforementioned research gaps, this study employs a Hierarchical Generalized Linear Model (HGLM) to investigate individuallevel and institution-level factors associated with student loan default among a sample of federal student loan recipients who attended a community or technical college in a statewide system of two-year public institutions. This research aims to bolster collective understanding regarding the determinants of loan default among borrowers who attend community college and the relative degree to which individual-level and institution-level variables influence student loan default outcomes at two-year public institutions.

\section{Background}

This study builds upon an extant body of research that delineates individual-level and institution-level factors associated with default among federal student loan recipients. Although perhaps counterintuitive, prior research demonstrates a higher student loan debt sum (or higher monthly repayment obligation) is generally not indicative of the likelihood that a borrower will default (Gross, Cekic, Hossler, \& Hillman, 2009; Hillman, 2014a; McKinney, Gross, \& Inge, 2014). Much more precise indicators of high student loan default risk include weak academic performance in college (as evidenced by a low grade point average) or early withdrawal (Gross, Cekic, Hossler, \& Hillman, 2009; Herr \& Burt, 2005; Hillman, 2014a; Podgursky, Ehlert, Monroe, \& Watson, 2002). In a few studies, exiting college prior to earning a credential is the strongest observed predictor of student loan default (Dynarski, 1994; Herr \& Burt, 2005; Wilms, Moore, \& Bolus, 1987). In addition, demographic characteristics correlate to student loan repayment outcomes; low-income borrowers and minority populations default at higher rates, even after controlling for factors such as academic success in college (Hillman, 2014a; Gross, 
Cekic, Hossler, \& Hillman, 2009). And, regardless of background characteristics and academic outcomes, borrowers who acquire employment and earn higher wages after exiting college are more likely to avoid default (Hillman, 2014a; Lochner \& MongeNaranjo, 2014).

The factors that are most indicative of student loan default embody the enrollment composition of American two-year public institutions. As compared to four-year colleges and universities, community colleges enroll a larger proportion of minorities and low-income students (Ma \& Baum, 2016). Further, as compared to peers at four-year institutions, community college students withdraw from college at a systematically higher rate and graduate at a systematically lower rate (National Center for Education Statistics, 2016).

Virtually all studies that employ statistical methods to identify individual-level determinants of default analyze sample data exclusively from four-year institution(s) (Dyl \& McGann, 1977; Gray, 1985; Greene; 1989; Herr \& Burt, 2005; Myers \& Siera, 1980; Steiner \& Tym, 2005; Thobe \& Deluca, 1997) or from a dataset that contains borrower repayment data from various postsecondary institution types and/or sectors (Dynarski, 1994; Flint, 1997; Hillman, 2014a; Knapp \& Seaks, 1992; Podgursky, Ehlert, Monroe \& Watson, 2002; Volkwein \& Szelest, 1995; Woo, 2002). Few studies focus exclusively on repayment and default among two-year public institutions, though exceptions include McKinney, Gross, and Inge (2014), Steiner and Barone (2014), and Wilms, Moore, and Bolus (1987).

Considering the general differences between the collective population of two- and four-year college attendees, and the degree to which these differences align with the 
determinants of student loan default as identified by previous research, raises questions about the generalizability and precision of the extant research as applied to the community college student population. Moreover, the dearth of research on the community college student population extends beyond generalizability concerns. An additional effect of the lack of studies that focus specifically on borrowers who attended a two-year public institution yields a corresponding gap in the inclusion of study variables that are distinctively relevant to the community college student population. For example, as discussed in greater detail in the next chapter, variables highly relevant to two-year student populations (such as college readiness and technical education credential attainment) are underdeveloped in the extant student loan default literature.

\section{Problem Statement}

Nationally, about one in five federal student loan recipients who attend a two-year public institution default on their student loans within three years (U.S. Department of Education, 2016a). Remarkably little research attention has been devoted exclusively to defaulters who attended a two-year public institution (McKinney, Gross, \& Inge, 2014; McKinney, Novak, \& Hagedorn, 2016; Steiner \& Barone, 2014). Considering the high rate of default among student loan recipients who attend community colleges, this is a critical research gap. The gravity of this issue is exacerbated by the fact that two-year public institutions serve a significant proportion of under-represented and underresourced students (Ma \& Baum, 2016). Ensuring the U.S. federal student financial aid system is both sustainable and equitable necessitates that the default problem be addressed. The Department of Education's Default Prevention and Management: A Plan for Student and School Success states that "one solution to preventing future defaults lies 
in understanding what caused past defaults" (U.S. Department of Education, 2016e, p. 7). Though this study does not aim to identify the causes of default, it aims to document individual-level and institution-level characteristics associated with default specific to borrowers who attend a two-year public institution.

\section{Purpose of the Study}

The purpose of this study is to identify factors related to federal student loan default among loan recipients who attended a two-year public institution in Kentucky's Community and Technical College System (KCTCS). The correlational research design employs a Hierarchical Generalized Linear Model (HGLM) to explore the direction and strength of a set of individual-level factors and institution-level factors and their relative impact on the likelihood that a borrower will default on his or her federal student loans at any point during the Department of Education's three-year default rate monitoring window. By examining factors associated with student loan default specific to the community college student population, this study aims to bolster work to develop policies and targeted interventions to reduce student loan default in two-year public sector institutions.

\section{Research Questions}

This study addresses the following research questions:

1) To what extent are individual-level factors related to federal student loan default among borrowers within a statewide system of public two-year postsecondary institutions? 
a. To what extent are demographic factors related to federal student loan default among borrowers within a statewide system of public two-year postsecondary institutions?

b. To what extent are college readiness factors related to federal student loan default among borrowers within a statewide system of public twoyear postsecondary institutions?

c. To what extent are academic factors related to federal student loan default among borrowers within a statewide system of public two-year institutions?

d. To what extent are financial aid factors related to federal student loan default among borrowers within a statewide system of public two-year postsecondary institutions?

e. To what extent are completion and transfer factors related to federal student loan default among borrowers within a statewide system of public two-year postsecondary institutions?

2) To what extent are institution-level factors related to federal student loan default among borrowers within a statewide system of public two-year postsecondary institutions?

a. To what extent is campus size, composition, and locale related to federal student loan default among borrowers within a statewide system of public two-year postsecondary institutions? 
b. To what extent are institutional performance factors related to federal student loan default among borrowers within a statewide system of public two-year postsecondary institutions?

c. To what extent are institutional spending factors related to federal student loan default among borrowers within a statewide system of public two-year postsecondary institutions?

d. To what extent are macroeconomic factors related to federal student loan default among borrowers within a statewide system of public twoyear postsecondary institutions?

3) What is the relative impact of individual-level and institution-level factors and federal student loan default among borrowers within a statewide system of two-year public postsecondary institutions?

\section{Definition of Terms}

This section provides operational definitions for technical terms relevant to the present study.

Cohort default rate: The Department of Education calculates and reports a cohort default rate (CDR) for each Title IV postsecondary institution on an annual basis. For institutions with more than 30 borrowers entering repayment in the given fiscal year, the

CDR is calculated by dividing the number of borrowers who enter repayment on a federal student loan(s) from a given institution during a given federal fiscal year and default on loans within three years, by the total number of borrowers who entered repayment during the federal fiscal year from the given institution (for institutions with 30 or fewer 
borrowers entering repayment a three-year average default rate is calculated) (U.S. Department of Education, 2016c). ${ }^{1}$

Community College: This term is used to describe "regionally accredited public colleges, who primarily offer an associate degree as their highest award" (American Association of Community Colleges, 2015, p. 24). In this study, the terms "community college" and "two-year public postsecondary institution" are used interchangeably.

Federal Student Loan: Federal student loans are funded by the federal government, and include Direct Subsidized Loans, Direct Unsubsidized Loans, and Federal Perkins Loans (Department of Education, 2017). ${ }^{2}$

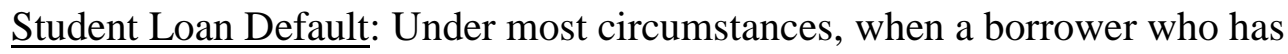
procured a federal student loan and exits the institution of higher education (either as a result of graduation or withdraw) at which the loan was procured, the loan enters a sixmonth grace period that begins on the borrower's last date of attendance (U.S. Department of Education, 2016c). At the conclusion of the six-month grace period, the loan enters repayment. If a borrower fails to make a payment as scheduled per the repayment terms of the loan, and does not have an approved plan for deferment or forbearance, the loan is considered delinquent the day after the loan payment date (U.S. Department of Education, 2016c). If a borrower fails to make a payment on his or her delinquent loan, the loan transition to default status; for most loans paid on a month basis the loan is considered in default after 270 days (roughly 9 months) of nonpayment ${ }^{3}$ (U.S.

\footnotetext{
${ }^{1}$ Prior to 2009, the window was two years however in 2008, The Higher Education Opportunity Act (the 2008 HEA reauthorization) mandated that the Department of Education expand the cohort default monitoring window from two to three years, beginning with borrowers entering repayment in federal fiscal year 2009 in an effort to more accurately track the percentage of borrowers who eventually default (U.S. Department of Education, 2012).

${ }^{2}$ Direct PLUS loans are also federal; however, they are not included in cohort default rates.

${ }^{3}$ The length it takes to enter default is dependent upon the payment schedule for the loan.
} 
Department of Education, 2016c). If a borrower's loan enters default, the borrower loses eligibility for deferment, forbearance, and additional federal student aid (U.S. Department of Education, 2016c).

\section{Nature of the Study}

In accordance with previous research on the determinants of student loan default, this study employs a quantitative, non-experimental, explanatory research design (Creswell, 2012) to describe the relationship between one binary dependent variable (loan default) and two levels of independent variables (individual and institutional). A Hierarchical Generalized Linear Model (HGLM) is employed to measure the strength and direction of association among the dependent and independent variables and statistically isolate the relative effect of each level of the independent variable (Raudenbush \& Byrk, 2002; Niehaus, Campbell, \& Inkelas, 2014; Osborne, 2016).

\section{Scope and Delimitations}

This study analyzes and documents individual-level and institution-level factors associated with student loan default among a sample of federal student loan recipients who attended a two-year public institution in the state of Kentucky, entered repayment on their federal student loan in Fiscal Year 2013, and were included in the Department of Education's Loan Record Detail Report ${ }^{4}$ (U.S. Department of Education, 2016c). The purpose of this study is to identify factors associated with default among borrowers enrolled in two-year public institutions, with a focus on factors that can inform default management and prevention strategies. Therefore, while there are precursors to default

\footnotetext{
${ }^{4}$ The Loan Record Detail Report (LRDR) is the file provided to postsecondary institutions from the U.S. Department of Education that contains the individual-level data used as the basis to calculate institutional cohort default rates.
} 
(i.e., delinquency), and other types of nonpayment (i.e., deferment and forbearance) (U.S. Department of Education, 2016b), the scope of this study extends only to federal loan default. Further, the individual-level variables in this study include only those that can be accessed by school officials (via the Department of Education repayment records, financial aid records, admissions data, and academic records). Thus, it is outside the scope of the present study to analyze post-college employment and wage effects on default outcomes.

The term validity refers to the degree to which the conclusions drawn from a study genuinely represent reality and the degree to which the findings can be applied beyond the scope of the analysis (Vogt, Gardner, \& Haeffele, 2012). The scope defined above, particularly with regard to the study setting and timeframe, presents a delimitation. This study analyzes point-in-time data for federal student loan recipients who attended a community/technical college in a single state and entered repayment on student loans in Fiscal Year 2013. In reality, student loan repayment is potentially influenced by national and regional social, political, and economic contexts. While the scope was necessary to ensure study feasibility, this decision introduces some degree of external validity threat and the generalizability of the findings to other contexts (particularly regarding time and region). These points should be considered when interpreting study findings (Creswell, 2012; Vogt, Gardner, \& Haeffele, 2012).

\section{Significance}

This study contributes to the extant body of literature by exploring the phenomena of student loan default among borrowers who attended an institution in a statewide community and technical college system. The examination of variables associated with 
student loan default in the context of a statewide higher education system presents a unique opportunity to help untangle the relationship between individual-level and institutional-level variables and to help explain considerable differences in cohort default rates among a set of similar two-year postsecondary institutions.

This study has implications that extend beyond student loan default to broader educational policy research contexts. Amid current dialogue surrounding the need to increase the accountability and performance of postsecondary institutions (U.S. Department of Education, 2006), and subsequent support among policymakers and legislators for performance-based funding initiatives (Dougherty \& Reddy, 2011), it is imperative to verify the extent to which standardized metrics - such as cohort default rates - are appropriate means to measure the postsecondary institutional effectiveness, particularly for institutions that serve a significant proportion of at-risk and vulnerable students. The study findings shed light on questions regarding the suitability of one-sizefits-all metrics in the varied landscape of American postsecondary education.

\section{Organization of the Study}

Chapter 1 presented a broad overview of student loan default and briefly discussed the need for additional research that explores this topic. The following chapter provides additional context for the present study, including a detailed exploration of the existing academic literature pertaining to student loan default. Chapter 3 describes and justifies the methodology and research design employed in this analysis, the findings of which are discussed in Chapter 4. The fifth and final chapter presents a summary of key findings, discussion about implications of the research, recommendations to practitioners and policy makers, and final study conclusions. 


\section{CHAPTER II}

\section{REVIEW OF LITERATURE}

This chapter presents a synthesis of the extant literature relevant to default on federal student loans in the United States. The first section of the chapter provides an overview of Human Capital Theory, a theoretical framework relevant to the principles underlying federal financial aid policy in the United States. Following is an overview of research related to student loan default; this portion of the chapter is divided into two sections: research pertaining to individual-level factors and to institution-level factors. The final portion of this chapter discusses gaps in the extant research as well as implications of these gaps in the context of community colleges.

\section{Theoretical Framework}

This is a quantitative study of student loan default, thus numerical data is used to empirically quantify, measure, and present a depiction of "objective reality" as a vehicle to contribute to the corpus of extant knowledge (Creswell, 2009). The subject of this study is federal student loan default among borrowers who attended a community college. To thoroughly explore patterns in debt repayment, one must consider the context in which the debt is situated, particularly when studying educational lending. Federal student loans provide the financial means for an individual to invest in human, as opposed to physical, capital, and are therefore inherently different from consumer loans that finance capital tied to tangible items or goods (Li, 2013). Therefore, scholarship that 
explores debt repayment (and nonpayment) with regard to federal student loans must contextualize the analysis within the federal financial aid system and the underlying principles upon which the system is structured. Human Capital Theory is a central tenant of the American system of federal financial aid and helps to clarify the purpose of providing federally-backed loans to borrowers to cover higher education expenses. As such, Human Capital Theory is employed to contextualize the empirical observations in this study. A brief overview of Human Capital Theory, its connection to the federal student loan program, and its relevance to the present study, follows.

\section{Human Capital Theory}

Human capital refers to "any stock of knowledge or characteristics [a] worker has (either innate or acquired) that contributes to his or her productivity" (Acemoglu \& Autor, 2011, p. 3) and encompasses "knowledge, understandings, talents, and skills" (Paulsen, 2001, p. 56). Human capital investment includes formal and informal educational experiences, training, and medical care expenses (Becker, 2008). The acquisition of human capital is innate by design, in that "people cannot be separated from their knowledge, skills, health, or values in the way they can be separated from their financial and physical assets" (Becker, 2008). Human Capital Theory is applied by "think[ing] of the set of marketable skills of workers as a form in which workers make a variety of investments" (Acemoglu \& Autor, 2011, p. 3).

Human Capital Theory maintains that the decisions that individuals make with regard to investment in human capital are akin to investments in physical capital, in that individuals weigh perceived costs and benefits prior to investment (Becker, 1975;

Paulsen, 2001). As applied to the context of investment in higher education, the theory 
maintains that individuals weigh the costs of college against the benefits of college (although this process may be implicit), including direct costs associated with attendance - tuition, fees, and books - and the indirect costs associated - such as time spent in school, money spent on child care, and lost or decreased wages as a result of time spent in school instead of working for compensation (Paulsen, 2001). The extent to which an individual believes that the benefits of education and training will eventually outweigh costs is significant component of the decision to pursue higher education and utilize student loans, particularly for low-income individuals (Volkwein \& Szelest, 1995).

\section{Human Capital Theory and Federal Student Loans}

In 1964, economist and seminal Human Capital Theory scholar Gary Becker published Human Capital, in which he equated investment in human capital to investment in physical capital in the context of higher education (Zumeta, Breneman, Callan, \& Finney, 2012, p. 65). Becker concluded that the "rate of [financial] return to an average college entrant is considerable, of the order of 10 or 12 percent per annum" (Becker, 1975, p. 232). The text received significant exposure to legislators and policymakers and played a substantial role in shaping policy conversations (Zumeta et al., 2012). Although the Higher Education Act (HEA) of 1965 and development of the American financial aid structure "emerged from the belief that expanding access to higher education was a worthwhile social investment" (Price, 2004, p. 32), new evidence of the value and return-on-investment of a postsecondary credential shifted conversations pertaining to the benefits of higher education; what was once considered a primarily social good pivoted to "the means for individual students to pursue and achieve selfinterested goals" (Price, 2004, p. 34). This collective mentality shift yielded a more 
tangible shift in policy: as policy makers demonstrated greater ease in facilitating borrowers' access to loans to pay for educational expenses, considering the demonstrated monetary returns, loans replaced grants as the primary financing mechanism for higher education, (Price; 2004; Zumeta et al., 2012).

The concept of return-on-investment continues to play an important role in policy conversations surrounding the federal student loan program (Gillen, Slingo, \& Zatynski, 2013; Oreopoulos \& Petronijevic, 2013). While scholars demonstrate that on average, the value of a college degree is worth the investment (Carnevale, Cheah, \& Hanson, 2015; Carnevale, Rose, \& Cheah, 2011), an underlying assumption that weaves throughout discussions concerning the payoff of a college credential is that benefits will materialize after the loan recipient earns a degree and subsequently can find a job with the potential to earn higher wages. However, as evidenced by a graduation rate of only $20 \%$ among public 2-year institutions nationally (National Center for Education Statistics, 2016) for many students who attend community college, the potential benefits of the investment may never materialize.

\section{The Relevance of Human Capital Theory}

The application of Human Capital Theory advances the present study by providing a structure for the selection of independent variables at both levels of the analysis. Human Capital Theory urges researchers to consider the costs and benefits of postsecondary education and the institution-level influences on the costs and benefits of enrollment in higher education, which is influenced by each group of individual-level factors (demographic, college readiness, academic success, financial aid, and completion/transfer) and institution-level factors (institutional size, composition, and 
locale, institutional performance, institutional spending, and macroeconomic factors).

The variables included in the empirical analysis capture the extent to which federal student loan recipients successfully obtained the human capital for which their loans were procured (as demonstrated by academic success and degree attainment) and the extent to which institutional and economic factors propelled borrowers' capacity for utilizing their earned capital (as demonstrated by the effect of institutional performance measures and regional economic indicators). Table 1 aligns factors pertaining to student loan default to costs and benefits associated with the Human Capital Theory model, thus demonstrating the use of Human Capital Theory as a guiding framework for analyzing student loan default and the research questions explored.

Table 1

Human Capital Theory and Student Loan Default

\begin{tabular}{llll}
\hline Costs & Corresponding IVs & Benefits & Corresponding IVs \\
\hline Tuition & Income & Credit Completion & Degree Attainment \\
Fees & Age & Degree Completion & Transfer Status \\
Books & Developmental & Successful Transfer & Credit Completion \\
Transportation & Education & Gainful Employment & First-Year Retention \\
Opportunity Cost / Lost & Requirements & & Rates \\
Wages & Credits and GPA & & First-Year Graduation \\
Child Care & Pell Status & Rates \\
& Dependency Status & Unemployment Rates \\
& Loan Debt & Median Annual Income \\
& Median Annual Income & & \\
& Percent Pell & & \\
& Percent Loans & &
\end{tabular}

\section{Additional Theoretical Considerations}

Notably, numerous scholars demonstrate that student loan repayment is driven by more than mere economics. As such, scholars have explored the phenomena of default through various other theoretical frameworks, including economic, psychological, behavioral, and organizational perspectives (Dynarski, 1994; Flint; 1997; Galloway \& 
Swail, 1999; Hillman, 2014a; Knapp \& Seaks, 1992; McKinney, Gross, \& Inge, 2014; Volkwein \& Szelest, 1995; Volkwein, Szelest, Cabrera, \& Napierski-Prancl, 1998; Webber \& Rogers, 2014). Following is a brief discussion of other theoretical perspectives that have previously informed student loan default analyses.

Ability to pay is an economic model that explicates the assumption that the availability of resources (i.e., income, wealth, and capital) and the prioritization of additional financial obligations are both inherently connected to an individual's ability to repay debt (Flint, 1997) and scholars apply the ability to pay lens to analyze student loan repayment (Dynarski, 1994; Flint, 1997; Volkwein \& Szelest, 1995; Volkwein, et. al., 1998). As pointed out by Volkwein and Szelest (1995), the ability to pay framework emphasizes the significance of both individual and familial income with regard to debt repayment, which validates the inclusion of personal and parental wealth factors, monthly payment burden, and additional debt obligation factors in student loan repayment analyses. In addition to resource availability, some scholars have applied psychological frameworks to explore additional reasons why borrowers might fail to repay loans according to promissory notes; for example, scholars considering loan repayment in the context of attitude formation theory surmise that satisfaction and personal attitudes may also impact repayment (Christman, 2000; Flint, 1997).

In an effort to more deeply contextualize loan repayment to a postsecondary education setting, scholars extend theories about students' experiences in college as a mechanism to study student loan repayment. For example, frameworks related to student retention and student-institution fit bolster and inform the analysis of student experiences and outcomes in and after college - including the repayment of student loans (Flint, 1997; 
Galloway \& Swail, 1999; Volkwein \& Szelest, 1995; Volkwein, et. al., 1998).

Considering the strong association between academic success and successful loan repayment (documented later in this chapter), models related to college student behavior and outcomes can provide important context to the issue of default.

Finally, as a mechanism to analyze the degree to which institutions impact student loan default outcomes, the use of organizational theory - structural/functional theory, in particular - elucidates assumptions about the interplay between institutional characteristics and organizational functioning (Volkwein \& Szelest, 1995; Volkwein et. al., 1998). As pointed out by Hillman (2014), theories of firm behavior clarify the external pressures that institutions face with regard to competitive markets and variation in the factors that impact outcomes across institutional types (Hillman, 2014a).

Collectively, the diverse perspectives employed to study student loan default in the extant research help to guide and expand insight into the phenomena of student loan default.

\section{Cohort Default Rates: A Contextual Summary}

This study analyzes U.S. Department of Education federal student loan records used to calculate cohort default rates (CDRs). To provide context for the analysis, this section contains a brief history of the derivation of CDRs, national federal student loan default rate figures, and a discussion regarding the use of CDRs as an accountability metric for American postsecondary institutions.

\section{A Concise History of Cohort Default Rates}

The Higher Education Act (HEA) of 1965 authorized the creation of the Guaranteed Student Loan (GSL) program and a need-based educational grant program, which thereby established the federal government's function as the primary facilitator of 
financial access to postsecondary education (Zumeta, et. al., 2012). Initially, eligibility to participate in the federal student loan program was based on students' demonstrated financial need, however, in response to rising tuition rates and growing concern about college affordability for the middle class, later modifications to the Higher Education Act eliminated income thresholds for program participation (Zumeta et al., 2012).

Concern over the cost of postsecondary education prevailed throughout subsequent decades as declining state revenue, bouts of inflation, and a number of recessions contributed to a steady rise in the cost of higher education in the U.S. (Cohen, 1998; Price, 2004; Zumeta et al., 2012). These factors, coupled with continued expanded access to federal student loans (including higher loan maximums and new loan programs), generated a sea change in the way in which students and families pay for higher education, characterized by a shift from away from grants towards loans as the primary mechanism by which American college students finance higher education (Cohen, 1998; Price, 2004; Zumeta et al., 2012). By the mid-1990s, loans outpaced grants as the primary mode by which students and families were paying for postsecondary education, which "represented a fundamental shift in the ways students and families finance college attendance" (Zumeta et al., 2012, p. 76). As Cohen (1998) stated, the American system of higher education is "dependent upon grants and loans made to all types of students at all levels and in all sectors" (p. 403).

The rising cost of higher education, coupled with an increase in the use of federal student loans to finance college costs, results in a mounting sum of over one trillion dollars' worth of federal student loan debt, which has simulated much concern among government officials and policymakers (Akers \& Chingos, 2014; Bricker, Brown, 
Hannon, \& Pence, 2015). A critical component in assessing the significance of the total debt sum and evaluating the degree to which the sum is problematic is an assessment of the rate in which the debt sum is repaid, and a key facet in the assessment of repayment is an identification of the proportion of borrowers who are not making payments according to the promissory note stipulations. Traditionally, default has been the primary metric to measure systematic nonpayment, ${ }^{5}$ perhaps due to the fact that federal loans are federally guaranteed, and the unpaid balances of defaulted loans are paid by the federal government. This "default cost" accrues significant monetary burden for the federal government and taxpayers; defaulted loans accounted to six billion dollars by the first fiscal quarter of 2016 (U.S. Department of Education, 2016d).

In 1990, amid concern over after allegations of fraud and abuse of the Guaranteed Student Loan program among for-profit institutions, congress passed the Student Loan Default Prevention Act of 1990, which established the annual cohort default rate reporting structure and a process for eradicating Title IV eligibility for institutions with default rates above the designated threshold (U.S. General Accounting Office, 1995). As mandated by the 1990 Act, the Department of Education is responsible for monitoring and reporting data related to the number and proportion of federal student loan recipients who default on their loans within a specified timeframe. Annually, the Department of Education uses National Student Loan Data System (NSLDS) data to calculate and report cohort default rate (CDR) for all Title IV postsecondary institutions. As defined in the previous chapter, the CDR indicates the percent of borrowers entering repayment in a

\footnotetext{
${ }^{5}$ As discussed in Chapter 1, a borrower is considered in default after nine months of nonpayment on the federal student loan (assuming the borrower has failed to set up an approved alternative payment plan) (Department of Education, 2016).
} 
given federal fiscal year, who default on their loans within three years (U.S. Department of Education, 2016c).

\section{Cohort Default Rates by Sector and Type}

The Department of Education reports CDRs at the institutional, sector, and state

level. Nationally, $11.3 \%$ of all borrowers who entered repayment on their loans in Fiscal Year 2013 had defaulted on their loans by 2015 - which equates to nearly 600,000 borrowers (U.S. Department of Education, 2016a). CDRs vary by substantially and systematically institutional sector. As indicated in Figure 1, cohort default rates are lowest among private sector institutions and highest among for-profit sector institutions.

Figure 1

Official Three-Year Cohort Default Rates, by Institutional Sector

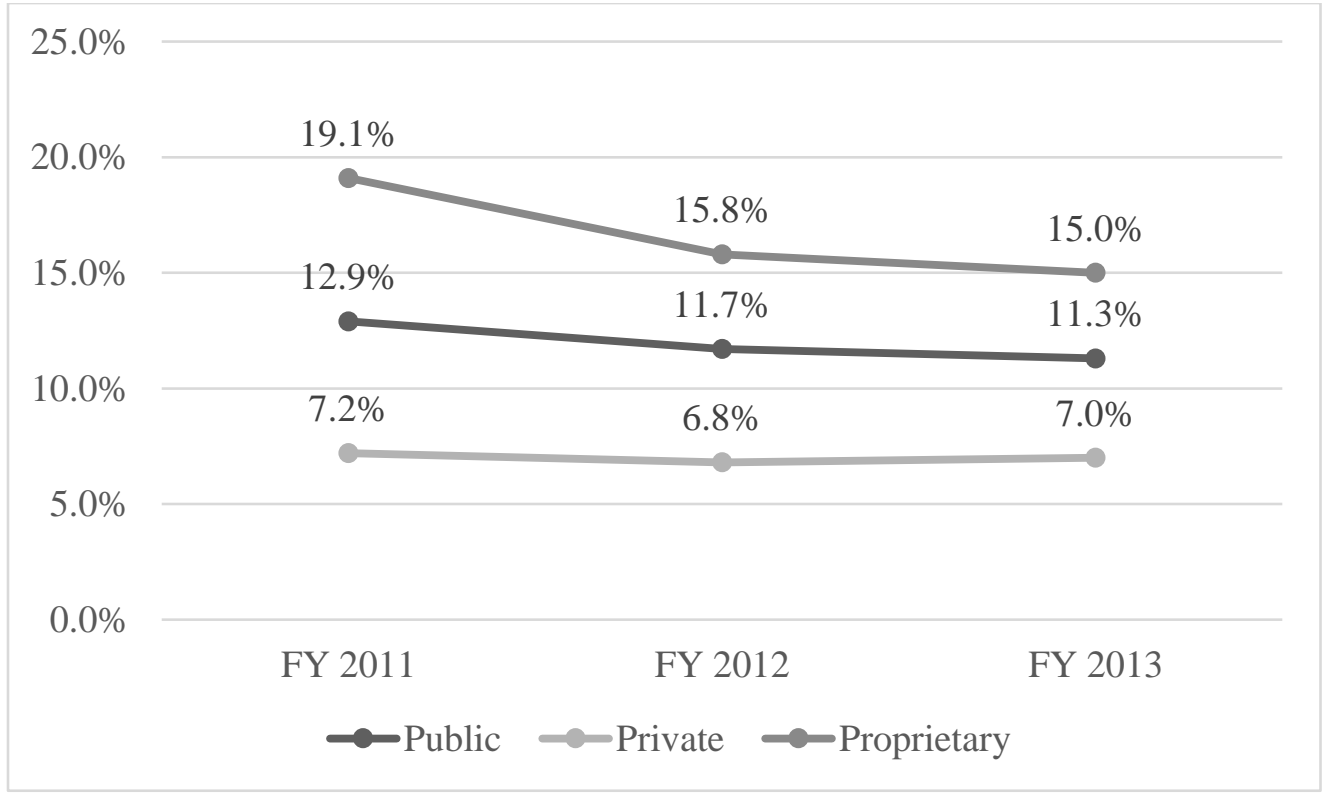

Source: Department of Education (2016a)

As indicated in Figure 2, cohort default rates among institutions in the same sector also vary considerably. In comparison to other institutional types in the public sector, two-year institutions consistently have the highest default rates. Among loan recipients 
who attend a two-year public institution, over 175,000 borrowers nationwide - or $18.5 \%$ defaulted at least once during the three-year default monitoring window (Department of Education, 2016a).

As discussed in the following literature review, the degree to which the variance in cohort default rates is attributable to institutional characteristics, as opposed to differences in enrollment of students by institutional type is a matter of debate; however, disparities in cohort default rates by sector seem to be at least somewhat driven by differences in the demographic composition of an institution's population (Goodell, 2016; Hillman, 2014a; Webber \& Rogers, 2014).

Figure 2

Official Three-Year Cohort Default Rates, Public Sector Institutions, by Type

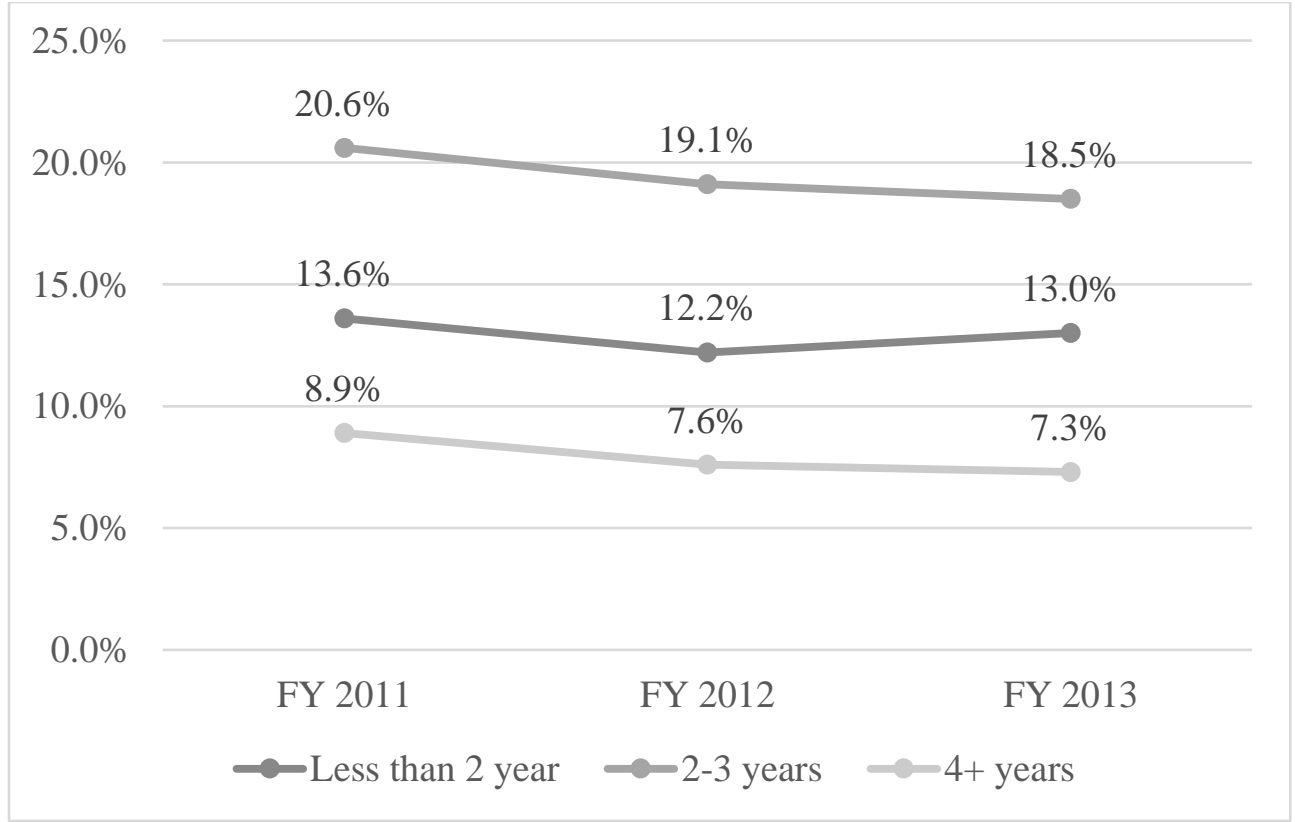

Source: Department of Education (2016a)

\section{Cohort Default Rates as an Institutional Accountability Metric}


The Student Loan Default Prevention Act of 1990 mandates that postsecondary institutions are held accountable for their cohort default rates and are subject to sanctions if rates exceed given thresholds (U.S. Department of Education, 2016c). If an institution's cohort default rate exceeds $30 \%$ in any given cohort year, the college is required to submit a Default Prevention Plan to the Department of Education (U.S. Department of Education e-CFR 668.217), in which the college must "identify the factors causing the default rate to exceed the threshold," "establish measureable objectives and the steps the institution will take to improve its cohort default rate," and "specify the actions the institution will take to improve student loan repayment" (U.S. Department of Education, 2012). If an institution's cohort default rate exceeds $30 \%$ for more than three years, institution risks losing eligibility to administer Title IV funds, which include federal student loans and income-based Pell grants (U.S. Department of Education, 2016c). Postsecondary institutions have the opportunity to appeal sanctions based upon economic disadvantage if the institution enrolls a high proportion of low-income students (U.S. Department of Education, 2016c).

Initial proposals for legislation to systematically track institutional default rates were met with great concern. Early discussions about cohort default rates raised questions regarding the "acceptable" default threshold given the nuances of providing loans to high-risk borrowers (McCormick, 1987; Emmert, 1978). In 1987, McCormick authored an article in which he challenged the then Deputy Under Secretary of Education's assertion that "any default rate is intolerable," noting that the high-risk students who are more likely to default "were the very students that federal financial assistance was designed to rescue, to aid" (p. 33) therefore default at some level may be 
inevitable. A 1988 General Accounting Office report echoed McCormick's sentiment, raising questions about the complexity of establishing sanctions for schools with high default rates. The report noted that the concept of a cohort default should be met with consideration of the student population of the institution: "In determining such a threshold, consideration should be given to the populations the schools serve. For example, a school with a large population of economically disadvantage students and a higher dropout rate might be expected to have a higher proportion of students who will default on their loans than other schools" (U.S. Government Accountability Office, 1988, p. 12-13).

Concerns about a universal CDR threshold and questions about appropriate default thresholds prevail (Gross \& Hillman, 2014a). Recently, analysts have proposed amendments to the current CDR metric in an effort to account for institutional differences. Gillen (2013) proposed pairing an estimated default rate (dependent upon Ability to Pay of the student borrower population) with an actual default rate, to account for baseline differences (Gillen, 2013), thus holding institutions accountable for cohort default rates yet simultaneously adjusting for demographic differences in the institutional populations (Gillen, 2013).

There is also concern over the fact that CDRs may not provide enough data about the outcomes of repayment. Default is only one measure of student loan nonpayment, and excludes borrowers who are delinquent or in forbearance, which also reflects repayment challenges. Cunningham \& Kienzl (2011) recommend "reframing the debate about student loan debt to include the causes and consequences of delinquency" as this “could go a long way toward improving borrowers' experiences, enhancing the student 
loan program, saving taxpayers' money, and perhaps contributing more broadly to higher education as a whole" (Cunningham \& Kienzl, 2011, p. 7).

\section{Factors Associated with Default on Student Loans}

This study builds on extant literature that examines loan repayment and default among federal student loan recipients. This section includes a summary of research relevant to factors associated with default on federal student loans. Collectively, scholars have identified a number of characteristics that correlate with a stronger or weaker probability of student loan default. This section contains an account of these characteristics, categorized by individual-level factors, and institution-level factors. Following is a summary of the few studies that examine student loan default among loan recipients who attended a public community college and a discussion of current gaps in the extant literature.

Notably, every study presented in this literature review employed a correlational, non-experimental research design to identify factors linked to student loan default (with the exception of a few studies that are solely descriptive in nature). A literature review by Gross, Cekic, Hossler, and Hillman (2009) notes many of the variables employed in loan default studies - in particular, demographic and background characteristics - are "manifestly entangled" (p. 20). Thus, while these studies document associations and relationships among variables, the research does not ascribe causation among the variables, nor does this literature review.

\section{Individual-Level Factors}

An extant body of research on student loan default documents individual-level variables that correlate to student loan default. An overview of these factors follows, 
categorized by: (1) demographic and background factors, (2) academic factors, (3) financial aid factors, and (4) post-college factors. The earliest loan default studies focused on background characteristics and aimed to distinguish between borrowers who may be pre-disposed to student loan default and those more likely to repay loans (Dyl \& McGann, 1977; Gray, 1985; Myers \& Siera, 1980). Later studies incorporate national multi-institutional datasets and post-college outcome variables to illustrate the nature of default as a phenomenon (Dynarski, 1994; Flint, 1997; Hillman, 2014a, Woo, 2002; Volkwein \& Szelest, 1995).

Background and Demographic Factors. The collective research on student loan default documents a strong relationship between student loan default outcomes and demographic factors, such as socioeconomic status and race/ethnicity. The sometimes inexplicable differences in student loan default rates that correlate to loan recipients' background characteristics connects student loan default to systemic social, racial, and economic inequity embedded in the American educational and social structure.

Race/Ethnicity. Most studies that examine student loan default indicate that Black and African American student loan recipients default at a rate systematically higher than White student loan recipients, even after accounting for characteristics such as family income and academic achievement (Barone, Steiner, \& Teszler, 2005; Dynarski, 1994; Flint, 1997; Gray, 1985; Greene, 1989; Herr \& Burt, 2005; Hillman 2014; Knapp \& Seaks, 1992; Lochner \& Monge-Naranjo, 2014; Podgursky, Ehlert, Monroe \& Watson, 2002; Steiner \& Teszler, 2005; Steiner \& Tym, 2005; Thobe \& DeLuca, 1997; Volkwein \& Szelest, 1995; Wilms, Moore, \& Bolus, 1987; Woo, 2002). A small number of studies conclude that Hispanic/Latino/a populations also default at higher rates than White 
borrowers (Barone, Steiner, Teszler, 2005; Herr \& Burt, 2005; Hillman, 2014a; Lochner \& Monge-Naranjo, 2014; Woo, 2002). In an analysis of Beginning Postsecondary Students Longitudinal Study (BPS) survey data, Hillman (2014) observed that among the multi-institutional sample of loan recipients, Black/African American and Hispanic/Latino/a borrower groups were about 9\% more likely to default on student loans as compared to White borrowers, even after controlling for demographic, academic, financial aid, and post-college employment characteristics (Hillman, 2014a).

In an effort to explain differences in default rates among race/ethnicity groups, Volkwein, Szelest, Cabrera, \& Napier (1998) analyzed National Postsecondary Student Aid Study (NPSAS:87) data disaggregated by race/ethnicity (White, Black/African American, and Hispanic/Latino/a borrowers). The researchers performed three regression models in order to compare patterns in the relative significance of predictors of loan default across each racial and ethnic group. The authors concluded that "the variables that reduce and increase loan default are substantially the same across minority and majority populations, but their influence on minorities is larger" (p. 225). For example, while failure to complete a Bachelor's degree was associated with loan default among all race/ethnicity groups, non-completion increased the probability that White borrowers would default by $8 \%$, whereas non-completion increased the probability that a minority borrower would default $18.2 \%$.

Differentiations in student loan repayment and default rate among race/ethnicity groups are inherently interwoven with corresponding differences in student loan utilization and debt burden; on average Black and African American students accumulate a larger proportion of debt as compared to White peers (Price, 2004; Addo, Houle, \& 
Simon, 2016; Scott-Clayton \& Li, 2016) and have higher rates of loan delinquency (Steinbaum \& Vaghul, 2016). However, inexplicable disparities in student loan repayment and default rates are undoubtedly rooted in structural and societal racism and inequity in the United States, which impacts higher education access, educational attainment, labor market equality, and unemployment rates (Addo, Houle, \& Simon, 2016; Jackson \& Reynolds, 2013; Steinbaum \& Vaghul, 2016). Ultimately, empirically testing the collective amalgamation of these factors is insurmountable, leaving the determinants of racial inequity palpable yet difficult to quantify. Nonetheless, the sharp and consistent disparities in the rate of loan default have led to calls for action to further investigate disparate default rates (Price, 2004; Zalaznick, 2016).

Although no study documents a lower probability of default among Black/African American borrowers, a few studies find no significant difference between the groups (Hakim \& Rashidian, 1995; McKinney, Gross \& Inge, 2014; Steiner \& Barone, 2014) and one study finds that Hispanic/Latino/a borrowers default at rates equal to White peers (Steiner \& Tym, 2005).

Among other race/ethnicity groups, the findings are often reported in aggregate (i.e. an aggregate "minority" group) due to smaller sample sizes, making findings more ambiguous; with the exception of Volkwein \& Szelest, 1995, who observed that Native Americans default at a significantly higher rate (26\% higher) than White borrowers.

Age. Borrowers who are older at the time in which they enter student loan repayment are at greater risk of default, according to previous research findings (Flint, 1997; Herr \& Burt, 2005; McKinny, Gross, \& Inge, 2014; Podgursky, Ehlert, Monroe, \& Watson, 2002; Steiner \& Teszler, 2005; Steiner \& Tym; Woo, 2002). One study 
concluded that for every one-year increase in a borrower's age beyond the age of 21 , the probability that the borrower will default increases by $3.0 \%$ (Flint, 1997, p. 343). Woo (2002) speculates that as compared to younger, traditional-age loan recipients, older students may have less of a familial/parental network to fall back on during repayment (p. 13). However, the correlation between age and default is questionable, as many studies find no significant relationship between age and rate of default after controlling for other significant variables (Barone, Steiner, Teszler, 2005; Dyl \& McGann, 1977; Hakim \& Rashidian, 1995; Hillman, 2014a; Knapp \& Seaks, 1992; Myers \& Siera, 1980; Stockham \& Hesseldenz, 1979).

Gender. A number of studies find that males tend to default at higher rates than females (Barone, Steiner, Teszler, 2005; Flint, 1994, 1997; Herr \& Burt, 2005; McKinney, Gross, \& Inge, 2014; Podgursky, Ehlert, Monroe, \& Watson, 2002; Steiner \& Barone, 2014; Steiner \& Teszler, 2005; Steiner \& Tym, 2005; Woo, 2002). The documented effects of gender on loan default vary considerably: Steiner \& Tym (2005) observed that females were "one percentage point less likely to default than males" (p. 3) while Woo (2002) observed that being female was associated with a $36 \%$ reduction in a borrower's probability of default (p. 13). Other researchers report gender differences are not significant when other control variables are included in the model (Hillman, 2014a; Knapp \& Seaks, 1992; Lochner \& Monge-Naranjo, 2014; Myers \& Siera, 1980; Thobe \& DeLuca, 1997; Volkwein \& Szelest, 1995; Wilms, Moore, Bolus, 1987).

Family Income. Expectedly, ability-to-pay impacts student loan repayment, and in turn, student loan default. Borrowers who report a smaller Adjusted Gross Income (parental income for dependent students) on the Free Application for Federal Student Aid 
(FAFSA) are more likely to default on student loans (Dynarski, 1994; Gray, 1985; Greene, 1989; Hakim \& Rashidian, 1995; Herr \& Burt, 2005; Hillman, 2014a; Knapp \& Seaks, 1992; McKinney, Gross, \& Inge, 2014; Thobe \& DeLuca, 1997; Steiner \& Tym, 2005; Wilms, Moore, \& Bolus, 1987; Woo, 2002). Similarly, studies that use a proxy for income, such as Expected Family Contribution (EFC) or eligibility for the income-based Pell Grant, also document higher rates of default among lower-income borrowers (Barone, 2006; Barone, Steiner, \& Teszler, 2005; Steiner \& Barone, 2014; Steiner \& Teszler, 2005). Wilms, Moore, \& Bolus (1987) found that borrowers who qualified for grants or scholarships were more likely to default, however, pointed out that considering the prevalence of need-based grants and scholarships, the difference is likely a proxy for socioeconomic status (p. 66).

Family Dynamics. Fundamentally connected to the relative impact of income is the dynamic of the family in which the reported income supports. As such, holding family income constant, some studies indicate that as family size increases, so does the risk of default (Dynarski, 1994; Hakim \& Rashidian, 1995; Hillman, 2014a; Volkwein \& Szelest, 1995; Woo, 2002). Volkwein \& Szelest (1995) observed that "having dependent children increases default probability by 4.5 percent per child" (p. 59). The extant research is decidedly inconclusive regarding the degree to which marital status impacts default; a few studies find that married borrowers are less likely to default (Dyl \& McGann, 1977; Gray, 1985; Volkwein \& Szelest, 1995), though many studies document no significant relationship (Barone, Steiner, \& Teszler, 2005; Flint, 1997; Hakim \& Rashidian, 1995; Myers \& Siera, 1980; Steiner \& Tym, 2005; Stockham \& Hesseldenz, 1979). Gross, Cekic, Hossler, and Hillman (2009) point out that families who report 
higher incomes are likely more able to provide a monetary "safety net" to borrowers who may struggle to repay loans.

Status as a First Generation College Student. Students with parents who attended college may be less likely to default on student loans, as demonstrated by studies conducted by McKinney, Gross, and Inge (2014), Steiner and Teszler (2005), and Volkwein and Szelest (1995). However, some studies find no significant relationship, including Dynarski (1994), Flint (1997), and Herr and Burt (2005). This relationship may be influenced by the connection between default and academic outcomes, as discussed below.

Academic Factors. A number of academic factors, related to both academic readiness prior to college enrollment and academic outcomes in college, are strongly and consistently associated with student loan repayment and default outcomes.

Pre-College Academics. Research suggests that academic achievement in high school is correlated with student loan repayment outcomes. Borrowers who enter postsecondary education with a higher high school class ranking (Barone, 2006; Barone, Steiner, \& Teszler, 2005; Flint, 1994; Herr \& Burt, 2005; Steiner \& Teszler, 2005) or grade point average (Ryan, 1993) default at lower rates. A few studies document slightly smaller rates of default among loan recipients who graduated with a high school diploma versus those who completed a General Equivalency Diploma (Dynarski, 1994; Steiner \& Barone, 2014; Wilms, Moore, \& Bolus, 1987; Woo, 2002), however, other analyses find no difference between these student groups (McKinney, Gross, \& Inge, 2014; Volkwein \& Szelest, 1995). In a 1993 analysis of repayment among student loan recipients from one four-year public institution, Ryan (1993) points out that: "poorer achievement of 
defaulters in high school persists to college and the contrasts between groups remain consistent from high school to college performance" (p. 35).

Presently, only one study examines the relationship between developmental/remedial education requirements and student loan default. Steiner and Barone (2014) report that among a sample of borrowers from one community college, students who were required to enroll in developmental education classes were up to 7 percentage points more likely to default, depending on the number of remedial education subjects in which were required to enroll (p. 10). Students who enter postsecondary education underprepared for college-level coursework often face significant barriers to success, and thus have lower rates of retention and degree attainment (Bailey, 2009). Thus, variables related to academic success drive success in college, which also correlates to successful repayment, as discussed next.

College GPA. Academic success in college is consistently found to be one of the strongest predictors of student loan repayment. Most studies find a significant relationship between college grade point average (GPA) and repayment on student loans (Barone, 2006; Barone, Steiner, \& Teslzer, 2005; Dyl \& McGann, 1977; Flint, 1994, 1997; Gray, 1985; Greene, 1989; Herr \& Burt, 2005; Myers \& Siera, 1980; Steiner \& Barone, 2014; Steiner \& Tym, 2005; Thobe \& DeLuca, 1997; Volkwein \& Szelest, 1995; Woo, 2002). Volkwein \& Szelest (1995) reported that for every one-point increase in a borrower's GPA, the probability that the borrower would default decreased by about 5 percent (p. 59).

Major. The association between default and a borrower's major in college is inconclusive. Many studies do not measure this variable, and among the studies that do, 
majors are categorized in various groups, making collective findings difficult to interpret. A few studies find that students enrolled in engineering, science, or technology schools and programs have the lowest probability of default (Dyl \& McGann, 1977; Lochner \& Monge-Naranjo, 2014; Steiner \& Teszler, 2005; Woo, 2002); though, considering the rigor of these programs, the degree to which this is simply a function of differences in academic ability and achievement is unclear (Volkwein \& Szelest, 1995). Further, as Woo (2002) notes, these majors tend to have better post-college employment rates and higher salaries, which could also be driving underlying differences in default (Woo, 2002). A few studies find higher rates of default among liberal arts majors (Gray, 1985; Herr \& Burt, 2005; Steiner \& Teszler, 2005). Notably, Flint (1997) observed that not a particular program or field of study, but "greater incongruence between undergraduate major and current employment" that correlated with default (p. 343).

Enrollment Persistence. Those who remain enrolled for a longer timeframe have better chances of repayment with no default. A few studies find that as the number of semesters a student is enrolled in postsecondary education increases, default risk decreases, with those exiting college as freshman at greatest risk of default (Barone, 2006; Barone, Steiner, \& Teszler, 2005; Gray, 1985; Herr \& Burt, 2005). Podgursky, Ehlert, Monroe, and Watson (2002) and Woo (2002) both report that borrowers who remained continuously enrolled (i.e., those who did drop out for one or more semesters during their duration of enrollment) were more likely to repay, regardless of graduation outcome.

Degree Completion. The most consistent predictor of default is failure to earn a postsecondary credential. Borrowers who drop out of college prior to earning a degree 
are most likely to default (Barone, 2006; Barone, Steiner, \& Teszler, 2005; Dynarski, 1994; Greene, 1989; Herr \& Burt, 2005; Hillman, 2014a; Campbell \& Hillman, 2015; Knapp \& Seaks, 1992; McKinney, Gross, \& Inge, 2014; Podgursky, Ehlert, Monroe, \& Watson, 2002; Ryan, 1993; Steiner \& Barone, 2014; Volkwein \& Szelest, 1995). Further, the effect of graduation is often large in magnitude. In 1992, Knapp and Seaks analyzed a statewide dataset of borrowers enrolled in two- and four-year public and private institutions in the state of Pennsylvania and observed that graduating with a postsecondary credential reduced a borrower's probability of default by 10 percentage points (p. 408). In Hillman's 2014 analysis of BPS, graduation reduced the risk of default by 20 percentage points.

Financial Factors. The notion that student loan default is related to financial aid - specifically, student loan debt sum - is intuitive, however, financial aid variables generally tend to be relatively less significant than other demographic and academic variables with regard to student loan default predictability.

Student Loan Debt Sum. Acquiring a larger sum of federal student loan debt is not markedly associated with a higher risk of default (Flint, 1994, 1997; Hillman, 2014a; Knapp \& Seaks, 1992; Volkwein \& Szelest, 1995; Woo, 2002). By squaring the linear loan debt sum among a national sample of borrowers in repayment on federal student loans, Hillman (2014) illustrated that the relationship between likelihood of default and loan debt sum is not linear but "gradual u-shaped" (p. 184); indicating that borrowers who drop out early are more likely to default but also have fewer opportunities to acquire student loans. In other words, as pointed out by Woo (2002), "high debt, for most borrowers, is a harbinger of success, not failure" (p. 15). 
Financial Aid Exit Counseling. A small number of studies measure the relationship between student loan default and a loan counseling session or exit interview upon exiting the institution and generally these studies document that those who complete an exit interview tend to have lower default rates (Barone, Steiner, \& Teszler, 2005; Steiner \& Teszler, 2005; Woo, 2002). In a study of 5,177 loan recipients from a single four-year public institution, borrowers who had completed an exit counseling session were less likely to default on student loans by approximately nine percentage points (Barone, Steiner, \& Teszler, 2005).

\section{Post-College Factors.}

The emergence of national research projects over the past few decades has facilitated the ability for scholars to incorporate post-college outcome variables into student loan repayment and default analyses. National data collection projects, such as the National Postsecondary Student Aid Study (NPSAS) and Beginning Postsecondary Students (BPS), both sponsored by the National Center for Education Statistics (NCES), facilitate the merge of institutional records and Department of Education with additional external data, including student surveys (National Center for Education Statistics, 2017). Collectively, these projects supply researchers with the capability to analyze nationally representative samples of student loan recipients, some of which incorporate students' post-college income and employment history, thus facilitating more nuanced data analysis (Dynarski, 1994; Flint, 1997; Hakim \& Rashidian, 1995; Hillman, 2014a; Volkwein \& Szelest, 1995). Other researchers employ state-level longitudinal datasets to achieve similar results (Woo, 2002). Collectively, these studies provide insight into the 
experiences of defaulters and repayers after they have exited higher education, as discussed below.

Employment. Employment is associated with student loan repayment, an unsurprising fact given the impact that ability-to-pay has on student loan default (Hillman, 2014a; Woo, 2002). As observed by Woo (2002), "the strongest post-school variable was filing for unemployment insurance;" all else being equal, borrowers who had filed for unemployment during repayment were $83 \%$ more likely to default (p. 16). In a 1984 descriptive survey analysis of 3,062 survey respondents from New York State who had entered repayment on student loans in a given timeframe, only $26 \%$ of borrowers who had defaulted were employed at the point in which their loans entered repayment, as compared to 80 percent of borrowers who had not defaulted on loans (Cross \& Olinsky, 1984, p. 13).

Wages. As employment relates to successful loan repayment, so follows wages. Borrowers who report higher post-college earnings are less likely to default (Dynarski, 1994; Flint, 1997; Hakim \& Rashidian, 1995; Herr \& Burt, 2005; Lochner \& MongeNaranjo, 2014; Woo, 2002). Unsurprisingly, post-college income has a significant effect on outcomes, one study found that a $\$ 10,000$ increase in wages reduced a borrower's likelihood of default by 30\% (Dynarski, 1994). Though these findings are axiomatic, they underscore role of ability-to-pay in borrower repayment rates.

\section{Institution-Level Factors}

As noted earlier in the chapter, the degree to which postsecondary institutions can influence a student loan recipient's repayment outcomes after the borrower exits the college or university has been a subject of debate since the formation of cohort default 
rates. Considering the aforementioned individual-level factors associated with loan default in conjunction with the income-based stratification of American higher education (Eckel \& King, 2004; Mullen, 2010; Smith, 2015) raises the question: Are sharp disparities in cohort default rates primarily a function of the students enrolled in each institutional type/sector, or do institutional characteristics also factor into student loan repayment and default outcomes?

Researchers have sought to answer this question by way of two general approaches. In studies that employ a multi-institutional sample of student loan recipients to measure individual-level repayment outcomes (such as many of the studies described in the individual-level factor section), researchers include an indication of the postsecondary institution in which the recipient procured a student loan, thus allowing the researcher(s) to measure the relative influence of institutional sector (i.e., public, private not-for-profit, or for-profit) and type (i.e., community colleges, four-year universities, etc.), controlling for many other individual-level characteristics (see Hillman, 2014a). More recently, researchers have employed cohort default rates as the criterion variable, thus facilitating exploration of the effect of institutional characteristics on cohort default rates. In addition to type and sector, these studies incorporate measures related to institutional characteristics (i.e., enrollment, region, cost and expenditures) and performance (i.e., graduation rates).

Institution Sector and Type. Institutional cohort default rates vary systematically by sector and type. Among institutions in the public sector, between Fiscal Year 2011 and 2013, national cohort default rates ranged between 11.3\% to 12.9\% among all public institutions; between $6.8 \%$ and $7.2 \%$ among all private institutions; and 
$15.0 \%$ and $19.1 \%$ among all proprietary for-profit institutions (U.S. Department of Education, 2016a). Among institutions in the same sector, two-year institutions have the highest default rates: in Fiscal Year 2013, 18.5\% of borrowers attending a two-year institution defaulted versus only 7.3\% among four year institutions (U.S. Department of Education, 2016a).

Sector. The cohort default rates for proprietary/for-profit institutions are consistently and substantially higher than colleges and universities in the public and private non-profit sectors. The degree to which this variation is a function of enrollment is debatable (Webber \& Rogers, 2014). A few previous studies find no increase in the odds of default among borrowers who attended a for-profit, after controlling for important student-level factors (Flint, 1997; Volkwein \& Szelest, 1995). However, there is amassing evidence that the cohort default rates at for-profit colleges and universities are more than simply a function of student characteristics. In an analysis of cohort default rates among 7,685 institutions, Goodell (2016) observed that cohort default rates at for-profit institutions were between 5 and 6 percentage points higher than similar notfor-profit institutions even after controlling for the cost of attendance, student enrollment composition, and graduation rates (p. 10). Similar findings have been documented in studies that analyze student-level data: in Hillman's (2014) HLM analysis of BPS data which incorporated both student- and institution-level characteristics, borrowers who attended a proprietary institution were 2-3 times more likely to default on student loans “even after controlling for students' demographic, socioeconomic, and academic profiles," including degree completion (p. 183). Other study findings concur, indicating that enrollment in a for-profit institution has a significant effect on student loan default 
risk, measurable above and beyond controls for factors related to repayment outcomes (Dynarski, 1994; Wilms, Moore, \& Bolus, 1987; Woo, 2002). Deming, Goldin, \& Katz (2012) concluded that "students who attended a for-profit have much higher default and non-repayment rates on federal student loans than do observationally similar students who attended a public or private nonprofit institution" (p. 153).

However, the specific contributors to the systematically higher default rates among for-profit institutions are less discernable. The systematic relationship between attending a for-profit institution and borrowers' likelihood of student loan default (and subsequent increases in institutional cohort default rates) provides a potential opportunity for insight into the feasible influencers of default at the institution level. More research is needed to identify these key factors and better understand the role that institutions play in student loan repayment.

Type. Although the rates of default are disparate among two-year and four-year public and private institutions, most analyses find no relationship between probability of default and the type of institution attended, after controlling for students' background, socioeconomic, and academic characteristics (Flint, 1997; Hillman, 2014a; Knapp \& Seaks, 1992; Podgursky, Ehlert, Monroe \& Watson, 2002). Podgursky, Ehlert, Monroe, \& Watson (2002) concluded "students in non-selective four-year colleges are equally likely to default as community college students" (p. 34). Ultimately, it appears that institutional type differences are explained by differences in selectivity; in analyzing institutional characteristics, Podgursky, Ehlert, Monroe, \& Watson (2002) concluded that in the sample, "selectivity is one institutional characteristic that seems to matter" (p. 34), the authors found that students enrolled at more selective institutions were less likely to 
default, after controlling for other characteristics. This holds in studies in which CDRs serve as the dependent variable, after controlling for student enrollment differences, CDR is not influenced by type (Belfield, 2013). In a study of CDRs among 4,285 institutions, Belfield noted that while 2-year public institutions had higher default rates, "the gaps are substantially a function of student composition and course provision" (p. 19).

Institution Characteristics. In an attempt to explain the characteristics that might influence default within institutions, researchers have incorporated a range of institutional factors related to enrollment, cost/expenditures, and accreditation. Note, due to the small number of studies that examine these characteristics, and the vast differences in the mechanism by which these variables are measured and explored, much is left undetermined. This section summarizes the small number of studies that explore additional characteristics.

Enrollment. An institution's size, in terms of the total number of students enrolled, is not significantly related to default, according to Ishitani \& McKitrick's (2016) analysis of CDRs of 479 four-year public postsecondary institutions. However, measures of the composition of the student body are related to default: mirroring the findings presented in studies that analyze a student-level default criterion variable, default rates are systematically higher among institutions which enroll a larger proportion of Pell grant recipients (Dillon \& Smiles, 2010; Goodell, 2016; Hillman, 2015b) and minority students (Belfield, 2013; Goodell, 2016; Hillman, 2015b; Ishitani \& McKitrick, 2016; Webber \& Rogers, 2014), males, and older student populations (Belfield, 2013; Goodell, 2016). 
Cost and Expenditures. Notably, among studies that analyze the relationship between the cost of attendance and student loan default rates, there appears to be either no significant relationship (Webber \& Rogers, 2014) or default rates tend to marginally decrease as cost increase (Goodell, 2016; Ishitani \& McKitrick, 2016). However, some research suggests how an institution allocates its resources appears to have an impact on cohort default rates, particularly with regard to instructional expenses. Galloway \& Swail analyzed cohort default rates at 80 Historically Black Colleges and Universities and concluded that for each one percent increase in the proportion of an institution's budget dedicated to instructional expenses, the institution's CDR decreased by roughly $1 / 3$ of a percent (p. 9), leading the authors to conclude that for institutions struggling to reduce cohort default rates, "the biggest "bang' for the institutional services 'buck" is to increase spending in this area (p. 10). Dillon \& Smiles (2010) also found that among HBCUs, as higher per-student expenditures increased, cohort default rates decreased.

Accrediting Body. Although only one recent study examined the role of the accreditation with regard to default, the findings are worth noting. Hillman (2015) analyzed cohort default rates among 4,448 two and four-year institutions and concluded "there are systematic patterns among accreditation agencies" with regard to default, institutions accredited by vocational programs are at greater risk of sanction (default rates higher than 30\%).

Institution Performance. The assumption underlying cohort default rates as an accountability metric is that better institutional performance may translate to better repayment outcomes. In the extant research, institutional performance is primarily measured in terms of graduation rates. Again, as degree completion relates to repayment, 
graduation rates also relate to repayment. Institutions with higher graduation rates tend to have lower CDRs, holding all else equal (Belfield, 2013; Webber \& Rogers, 2014; Hillman, 2015b; Goodell, 2016). Hillman (2015b) observed that for each one-point increase in an institution's IPEDs graduation rate the odds of sanction (i.e., a CDR higher than the $30 \%$ threshold) decreases "by more than two-fold" (p. 576).

Macroeconomic Variables. At the intersection of borrower-level and institutionlevel outcomes are the macroeconomic variables that impact the lives of students after they exit postsecondary institutions. Individuals do not exit college in a vacuum; the larger macroeconomic context impacts a borrower's post-college experiences and outcomes on a personal level. These factors may also present implications for postsecondary institutions, as these macroeconomic variables are inherently connected to the economy and geographic area in which a college is situated and the economic and demographic region in which the institution serves. While only a few studies apply macroeconomic data to study student loan default outcomes, the few studies that employ these characteristics suggest that economic context bears a weighty significance in terms of loan repayment and default.

Unemployment Rates. In an analysis of National Postsecondary Education Aid Study (NPSAS) data, Hakim \& Rashidian (1995) employed economic theory to analyze student loan repayment and default over time, and concluded that "national unemployment is found to be the primary economic cause of default" (p. 459). In a more recent analysis, Ishitani \& McKitrick (2016) evaluated cohort default rates among 479 public four-year institutions and observed that for every percentage point increase in the statewide unemployment rate (in which the postsecondary institution was located), 
institutional default rates increased by about a third of a percentage point (p. 27). A 2013 thesis also concluded documented a significant relationship between unemployment rates and national cohort default rates (Lundgren, 2013).

Region. Two studies incorporate state-level regional and macroeconomic measures to identify relationships associated with CDRs and both studies find that region is related to CDR in terms of geography (Ishitani \& McKitrick, 2016) and state appropriations (Webber \& Rogers, 2014). Ishitani \& McKitrick (2016) studied the relationship between CDRs and institution-level and state-level variables, and observed that institutions "situated in town or rural areas" tended to have slightly higher rates of default, as compared to institutions located in a suburban area (p. 25).

\section{Student Loan Default Outcomes Among Community College Student Populations}

As previously noted, most of the academic research referenced in this chapter is derived from studies that analyze data from four-year institutions or multi-institution datasets. However, there are a few exceptions. Following is a brief overview of the each of the handful of studies that focus exclusively on federal student loan recipients who attended a community college followed by a discussion of the gaps in the extant research.

Christman (2000) presented a descriptive analysis of defaulters who attended a single two-year public institution. The data indicated that many defaulters faced significant academic challenges: among the sample of defaulters, nearly seventy percent had failed at least one course, more than half were on financial aid probation at least once, and only nine percent had earned an Associate degree (p. 23). In a more recent descriptive analysis of repayment outcomes among borrowers who attended an institution in Iowa's community college system, $90 \%$ of those who defaulted had not earned a 
credential and $60 \%$ had accumulated less than fifteen credit hours (Campbell \& Hillman, 2015).

Among published research that focuses exclusively on federal student loan default among borrowers who attended a two-year public institution, three studies employ regression (logistic regression and/or discriminant analysis) to statistically compare borrowers who did and did not default on student loans. These studies document a correlation between academic success and repayment outcomes similar to findings prevalent in four-year and multi-institutional studies. Wilms, Moore, and Bolus (1987) concluded that among a sample of Guaranteed Student Loan (GSL) recipients who attended a community college and/or vocational school in California, default was primarily a function of individual-level characteristics, and in particular, degree completion (Wilms, Bolus, \& Moore, 1987). More recently, McKinney, Gross, and Inge (2014) extracted a sample of borrowers who had obtained a federal loan from a two-year public institution from the National Center for Education Statistics Beginning Postsecondary Students longitudinal survey (BPS:04/09). Among the sample, borrowers were most likely to default if they were male ( $186 \%$ higher default odds), if they had not earned a postsecondary credential (160\% higher default odds), or if they were a firstgeneration college student (143\% higher default odds). Borrowers enrolled in a technical program (such as those pursuing an Associate in Applied Science or an occupational certification) were also more likely to default (McKinney, Gross, \& Inge, 2014).

In the only study that analyzes the relationship between college readiness and student loan default, Steiner and Barone (2014) conducted a logistic regression analysis with loan repayment data for 4,621 federal student loan recipients who attended Austin 
Community College in Texas. The researchers developed two regression models: a FirstSemester Model and an Exit Model. The First-Semester model included only variables measurable prior to or directly after a borrower's first term of enrollment; the Exit Model incorporated additional variables measureable upon a borrower's final enrollment term and subsequent exit from the institution. The Exit Model mirrored findings from previous research: borrowers who earned a credential and accumulated a higher sum of student loan debt were significantly less likely to default. However, Steiner and Barone discovered that measures included in the first-semester model were "in many cases ... as successful in predicting default as similar measurements that one can make when borrowers exit" (Steiner \& Barone, 2014, p. 11). Four variables in the First-Semester Model were significantly related to student loan default: "a lower first-semester grade point average (GPA), a higher first-semester Pell grant amount, the need for developmental education coursework, and being male" (p. 3). Steiner and Barone (2014) call attention to the practical implications of the First-Semester Model findings: if institutions can identify key predictors of student loan default after a student is enrolled for only one term, institutions can establish early intervention efforts targeted at borrowers at greatest risk of default. These findings deem both developmental education and first-semester variables worthy of additional investigation.

Gaps in Student Loan Default Research. The scarcity of research that exclusively focuses on student loan default among community college students yields a critical research gap when considering the application of the extant student loan default research to the community college student population. Further, the focus on data from four-year institutions or multi-institutional studies yields a dearth in the exploration of 
variables that are highly relevant to the community college population. For example, more than two-thirds of community college students are required to take at least one remedial education course (Chen \& Simone, 2016) and students who require developmental education are more likely to drop out of college prior to completion (Bailey, 2009; Bailey \& Smith Jaggers, 2016). While students who are required to take developmental education classes obtain federal student loans at comparable rates to college-ready peers (McKinney, Novak, \& Hagedorn, 2016), only one study that explores student loan default incorporates a measure of college readiness (Steiner \& Barone, 2014). Also, Steiner and Barone (2014) employ a dichotomized variable to analyze the effect of developmental education requirements on student loan default (i.e., 'required developmental in the subject' versus 'did not require developmental in the subject'); however, in reality college readiness occurs on a continuum, and dichotomizing a variable may obscure measurable effects (Osborne, 2013). Therefore, further research is needed to ascertain the measurable relationship between the continuum of college readiness (for example, placement scores) and default risk. This relationship has further implications when considering extant research that suggests that students may not understand the terms of their loans (McKinney, Mukherjee, Wade, Shefman, \& Breed, 2015). If a loan recipient's college placement exam score indicates that he or she is not college-ready for math or reading, this impacts information accessibility with regard to providing details on the student loan terms and is cause for consideration in developing effective interventions.

Another variable missing in the extant student loan default research pertains to transfer status among federal student loan recipients. If a student obtains a federal 
student loan at a community college, and then transfers to another institution, once he or she enters repayment the community college remains accountable for the default outcomes associated with the loans (U.S. Department of Education, 2016c). The community college student population is highly transient, and many successful students transfer to a four-year institution prior to earning a credential; thus, failing to include a transfer status indicator when analyzing student loan default among community college students presents two problems: (1) the measure of successful completion is ambiguous, as it there is no distinction between borrowers who drop out and borrowers who transfer to a four-year institution and (2) the potential variables associated with default - such as transferring to a proprietary institution - may go unrealized, as there is no mechanism to identify transient borrowers. Therefore, understanding the role of transfer status may provide additional explanatory power in understanding student loan outcomes.

Finally, the impact of the type of credential that a borrower attains is another underdeveloped variable in the scope of student loan default research. Many community colleges offer shorter-term diplomas and certificates in addition to two-year Associate degrees. Few studies measure differences in default outcomes with regard to technical and liberal arts degree attainment or differentiate between certificates, diplomas, and Associate degree attainment (McKinney, Gross, and Inge (2015) and Steiner and Barone (2014) are exceptions). Considering the relationship between post-college employment, wages, and default, the impact of credential level is certainly worth additional exploration. 


\section{Summary}

Collectively, the extant research presents a complex, and somewhat convoluted, depiction of the drivers of student loan default. The research is clear in that there are a number of variables that are undoubtedly related to default, namely: socioeconomic status, academic achievement, and post-college employment and wages. These individual-level findings are mirrored in the institution-level data: institutions that are more selective and have higher degree attainment rates produce borrowers who are less likely to default. These findings are intuitive and are connected to the foundation of Human Capital Theory: borrowers who are more successful and find post-college employment are able to repay loans, while lower-income borrowers may experience financial barriers to repayment.

However, suppositions about the factors associated with student loan default are imprecise in that there seem to be additional factors impacting borrower default risk. There are inexplicable differences with regard to default rates when disaggregated by race/ethnicity. Institution-level factors appear to be a factor, but the extent and modes by which institutions play a role remains indeterminate. Identifying the specific actions that institutions can take to prevent default requires a more nuanced understanding of the relative impact of institutional characteristics on default outcomes.

Furthermore, the relationship between background and academic variables related to student loan default - such as socioeconomic indicators (income, Pell recipient status), race/ethnicity, and enrollment outcomes could potentially be obscured when applied to the two-year college student population, particularly when variables appropriate to the two-year student population (college readiness, transfer, and credential attainment) are 
missing from statistical models. As compared to four-year institutions, community colleges enroll a greater proportion of low-income and minority students (Ma \& Baum, 2016) and a significant proportion exit two-year institutions prior to earning a credential (National Center for Education Statistics, 2016). Yet, the majority of borrowers - even many who meet the at-risk criteria - do not default.

Collectively, this chapter documents unanswered questions and gaps regarding the phenomena of student loan default among borrowers who attend a two-year public institution. This study aims to address present resolve for some of the lingering questions. 


\section{CHAPTER III}

\section{METHODS}

The purpose of this study is to identify and describe individual-level and institution-level factors associated with student loan default among federal student loan recipients who attended a two-year public institution. This chapter contains a comprehensive overview of the study research methodology with detail sufficient to facilitate replication. The chapter begins with an overview of the research questions and design followed by information about the study setting, population, and sample. A procedural discussion regarding the logistics of data collection and the operationalization of study variables follows. The next portion of the chapter presents a technical overview of the data and statistical analyses employed, followed by a discussion about the assumptions and limitations of the study. In closing, ethical considerations related to data collection and analysis are disclosed.

\section{Research Questions}

A tenet of robust research is that procedural choices related to research planning and design are driven by the research question(s) posed (Vogt, Gardner, \& Haeffele, 2012). The methods proposed and described in this section are guided by the following research questions: 
1) To what extent are individual-level factors related to federal student loan default among borrowers within a statewide system of public two-year postsecondary institutions?

a. To what extent are demographic factors related to federal student loan default among borrowers within a statewide system of public two-year postsecondary institutions?

b. To what extent are college readiness factors related to federal student loan default among borrowers within a statewide system of public two-year postsecondary institutions?

c. To what extent are academic factors related to federal student loan default among borrowers within a statewide system of public twoyear institutions?

d. To what extent are financial aid factors related to federal student loan default among borrowers within a statewide system of public two-year postsecondary institutions?

e. To what extent are completion and transfer factors related to federal student loan default among borrowers within a statewide system of public two-year postsecondary institutions?

2) To what extent are institution-level factors related to federal student loan default among borrowers within a statewide system of public two-year postsecondary institutions? 
a. To what extent is campus size, composition, and locale related to federal student loan default among borrowers within a statewide system of public two-year postsecondary institutions?

b. To what extent are institutional performance factors related to federal student loan default among borrowers within a statewide system of public two-year postsecondary institutions?

c. To what extent are institutional spending factors related to federal student loan default among borrowers within a statewide system of public two-year postsecondary institutions?

d. To what extent are macroeconomic factors related to federal student loan default among borrowers within a statewide system of public two-year postsecondary institutions?

3) What is the relative impact of individual-level and institution-level factors and federal student loan default among borrowers within a statewide system of two-year public postsecondary institutions?

\section{Research Design}

As the research questions specify, the objective of this study is to document the relationship between one dependent variable - federal student loan default - and various individual-level and institution-level independent variables. This is a quantitative, descriptive, and non-experimental study: the relationships analyzed and described derive from institutional records and other preexisting databases in which no variables were manipulated and no intervention occurred (Creswell, 2012). The study employs a correlational research design with an explanatory focus; this is an appropriate framework 
for investigating the nature and strength of the relationship between two or more variables (Creswell, 2012).

The criterion (dependent) variable is a binary indication of whether or not a federal student loan recipient (the unit of analysis) defaulted on his or her federal student loan(s) at any point during the U.S. Department of Education's official three-year default monitoring timeframe (U.S. Department of Education, 2016c). The explanatory (independent) variables include individual-level variables (grouped by demographic factors, college readiness factors, academic factors, financial aid factors, and completion and transfer factors) and institution-level variables (grouped by institutional size, composition, and locale factors, institutional performance factors, institutional spending factors, and macroeconomic factors). An operational definition for each explanatory variable is included later in the chapter.

\section{Setting}

This study examines student loan default and repayment data among borrowers who attended a two-year public postsecondary institution located in the state of Kentucky. Kentucky is situated in the southeastern region of the United States and has an estimated population of approximately 4.4 million (U.S. Census Bureau, 2016). The state encompasses a geographically and economically diverse region, which includes the rural Appalachian Mountains, the agricultural Bluegrass country, and several suburban and urban metropolitan areas (Dykeman \& Wilford, 2015). Current national data indicates that Kentucky lags in comparison to other states with regard to measures of economic prosperity and educational attainment. According to U.S. Census Bureau 2015 estimates, Kentucky's Median Household Income was $\$ 45,215$, ranking $47^{\text {th }}$ in comparison to other 
states (U.S. Census Bureau, 2015); the same year, an estimated 18.5\% of Kentuckians were earning less than the poverty threshold (U.S. Census Bureau, 2015).

With regard to educational attainment, an estimated $85.1 \%$ of Kentucky residents aged 25 and older have attained a high school or general equivalency diploma and $23.3 \%$ have earned a Bachelor's degree, ranking $45^{\text {th }}$ and $47^{\text {th }}$ in the nation, respectively (U.S. Census Bureau, 2015). Notably, despite low rates of educational attainment in comparison to other states, Kentucky's degree production has grown substantially in the last decade: according to a 2016 report by the Kentucky Council on Postsecondary Education, "the total number of degrees and credentials awarded in Kentucky has increased 53 percent since 2004-2005," with the highest growth occurring in the two-year public institution sector (Kentucky Council on Postsecondary Education, 2016, p. 2).

There are sixteen public two-year postsecondary institutions in Kentucky. In 1997, the Kentucky General Assembly passed House Bill 1 (HB1), which consolidated all sixteen institutions under one comprehensive statewide system, the Kentucky Community and Technical College System (KCTCS), responsible for overseeing all sixteen institutions (Tollefson, Garrett, \& Ingram, 1999). KCTCS is governed by one 14member Board of Regents, eight of whom are appointed by the Governor and six of whom are elected by members of the faculty, nonteaching staff, and students (two electees per group) (Kentucky Community and Technical College System, 2017a). Each KCTCS college has its own Board of Directors (responsible for overseeing the operating budget and approving the institution's strategic plan, per KRS 164.600) and is independently accredited by the Southern Association of Colleges and Schools Commission on Colleges (Kentucky Community and Technical College System, 2017b). 
Table 2 includes a list of the sixteen public, two-year community KCTCS institutions, the institution's campus setting, and Fall 2015 enrollment figures.

Table 2

Two-Year Public Institutions in the State of Kentucky

\begin{tabular}{|c|c|c|}
\hline Institution Name & Campus Setting ${ }^{6}$ & $\begin{array}{l}\text { Fall } 2015 \\
\text { Enrollment }\end{array}$ \\
\hline Ashland Community \& Technical College & City: Small & 2,728 \\
\hline Big Sandy Community \& Technical College & Town: Remote & 4,938 \\
\hline Bluegrass Community \& Technical College & City: Large & 10,388 \\
\hline Elizabethtown Community \& Technical College & City: Small & 6,301 \\
\hline Gateway Community \& Technical College & Suburb: Large & 4,581 \\
\hline Hazard Community \& Technical College & Town: Remote & 3,238 \\
\hline Henderson Community College & Rural: Fringe & 1,561 \\
\hline Hopkinsville Community College & Town: Distant & 3,120 \\
\hline Jefferson Community \& Technical College & Suburb: Large & 12,138 \\
\hline Madisonville Community College & Rural: Fringe & 4,261 \\
\hline Maysville Community \& Technical College & Rural: Fringe & 3,158 \\
\hline Owensboro Community \& Technical College & Rural: Fringe & 3,974 \\
\hline Somerset Community College & Town: Remote & 6,386 \\
\hline Southcentral Community \& Technical College & City: Small & 3,962 \\
\hline $\begin{array}{l}\text { Southeast Kentucky Community \& Technical } \\
\text { College }\end{array}$ & Town: Distant & 3,111 \\
\hline West Kentucky Community \& Technical College & Town: Remote & 5,980 \\
\hline
\end{tabular}

For Fiscal Year 2013, Kentucky's statewide cohort default rate was $15.5 \%$, the third highest state-level rate in the nation (U.S. Department of Education, 2016f). In response, the Kentucky Council on Postsecondary Education asserted in a 2016 report that Kentucky "colleges and universities should play a more active role than in the past in

\footnotetext{
${ }^{6}$ Campus Size and Setting is per IPEDS, based on Carnegie Classifications 2005 definitions.
} 
designing intrusive intervention strategies for at-risk borrowers" (Kentucky Council on Postsecondary Education, 2016, p. 5).

\section{Population and Sample}

The target population includes federal student loan recipients who attended a twoyear public postsecondary institution in the United States. In Fall 2014, roughly 6.5 million American college students were enrolled in a public 2-year institution (National Center for Education Statistics, 2015). About $60 \%$ of students enrolled in public twoyear institutions receive some form of financial aid (grants, loans, Veteran's benefits, and/or Work-study) and about 20\% borrow a federal student loan (Juszkiewicz, 2014). Nationally, in fiscal year 2013, $18.5 \%$ of borrowers from two-year public institutions defaulted on their student loans during the Department of Education's 3-year cohort default rate monitoring window (U.S. Department of Education, 2016c).

This study is restricted to a nonrandom sample of borrowers who attended any institution in the Kentucky Community and Technical College System and entered repayment on federal student loans between October 1, 2012 and September 30, 2013, and were therefore included in the Department of Education's official cohort default rate metric for fiscal year 2013 for a KCTCS institution. At the outset of this study, fiscal year 2013 was the most recent year for which cohort default rate data was available.

A KCTCS system-level Financial Aid Office oversees financial aid offices situated in each of the sixteen community colleges. As indicated in Table 3, among all KCTCS institutions, 25,873 borrowers were counted in KCTCS CDR for in fiscal year 2013. ${ }^{7}$ Despite KCTCS colleges’ shared oversight, mission, and comparable financial aid

7 This count contains duplicates as some borrowers attended and obtained loans from more than one KCTCS institution, and were therefore included in Cohort Default Rate for multiple institutions. 
policies, cohort default rates vary considerably across the sixteen institutions, ranging from $21.0 \%$ to $31.9 \%$ in Fiscal Year 2013 (U.S. Department of Education, 2016a).

Table 3

Three-Year Cohort Default Rates Among KCTCS Institutions

\begin{tabular}{|c|c|c|c|}
\hline & $\begin{array}{l}\text { No. Entering } \\
\text { Repayment in } \\
\text { Cohort }\end{array}$ & $\begin{array}{l}\text { No. in } \\
\text { Default }\end{array}$ & $\begin{array}{l}\text { CDR } \\
\text { FY2013 }\end{array}$ \\
\hline Ashland Community \& Technical College & 1,118 & 337 & $30.1 \%$ \\
\hline Big Sandy Community \& Technical College & 947 & 256 & $27.0 \%$ \\
\hline Bluegrass Community \& Technical College & 4,459 & 1,002 & $22.4 \%$ \\
\hline Elizabethtown Community \& Technical College & 2,428 & 625 & $25.7 \%$ \\
\hline Gateway Community \& Technical College & 1,631 & 480 & $29.4 \%$ \\
\hline Hazard Community \& Technical College & 756 & 219 & $28.9 \%$ \\
\hline Henderson Community College & 479 & 132 & $27.5 \%$ \\
\hline Hopkinsville Community College & 1,143 & 263 & $23.0 \%$ \\
\hline Jefferson Community \& Technical College & 4,364 & 1,120 & $25.6 \%$ \\
\hline Madisonville Community College & 714 & 150 & $21.0 \%$ \\
\hline Maysville Community \& Technical College & 1,149 & 347 & $30.2 \%$ \\
\hline Owensboro Community \& Technical College & 956 & 252 & $26.3 \%$ \\
\hline Somerset Community College & 2,676 & 727 & $27.1 \%$ \\
\hline Southcentral Community \& Technical College & 1,285 & 373 & $29.0 \%$ \\
\hline Southeast Community \& Technical College & 636 & 203 & $31.9 \%$ \\
\hline West Kentucky Community \& Technical College & 1,132 & 301 & $26.5 \%$ \\
\hline
\end{tabular}

Source: U.S. Department of Education, 2016

\section{Procedures}

For the purpose of this study, a dataset was developed that contained information compiled from five sources: National Student Loan Data System (NSLDS) Loan Record Detail Reports (LRDR), Kentucky Community and Technical College System's Decision 
Support System (KCTCS DSS), the National Center for Education Statistics (NCES) Integrated Postsecondary Education Data System (IPEDS), the United States Census Bureau, and the Bureau of Labor Statistics (BLS). Following is a detailed description of the process employed to assemble the dataset for this study.

Each fiscal year the U.S. Department of Education provides postsecondary institutions with a Loan Record Detail Report (LRDR) that details data extracted from the National Student Loan Data System (NSLDS) used to calculate the postsecondary institution's cohort default rate. The report contains a loan repayment status for each borrower who entered repayment during the cohort fiscal year, which the institution reviews for accuracy (U.S. Department of Education, 2016c). The LRDR file contains identifiable student data (including Social Security Numbers) for each borrower from the institution who entered repayment during the indicated fiscal year. The file contains an indication of the borrower's default status for the Department of Education's official cohort default rate calculation and select loan records for each loan recipient. The researcher obtained LRDR data for fiscal year 2013 for each public two-year postsecondary institution in Kentucky. Upon receipt of the LRDR files, Social Security Numbers and corresponding default status for each of the federal loan recipients who entered repayment in the indicated year were extracted from the dataset.

The KCTCS Decision Support System (DSS) is an Oracle database and is the repository for institutional data for all KCTCS institutions. The database contains individual-level demographic, academic, and financial aid records. The Social Security Numbers (SSNs) collected from the LRDR report served as the matching variable to 
retrieve select individual-level variables from DSS for each borrower included in the LRDR files for KCTCS institutions in Cohort Fiscal Year 2013.

Institutional data was retrieved from the Integrated Postsecondary Education Data System (IPEDS), the primary system by which institutions report data to the U.S. Department of Education and the National Center for Education Statistics (NCES). As mandated by the Higher Education Act, all Title IV postsecondary institutions are required to provide data about institutional enrollment, program completion and graduation rates, cost, student financial aid and personnel and finances via annual surveys (National Center for Education Statistics, 2017). IPEDS data serves as a primary data resource for researchers and policymakers (National Center for Education Statistics, 2017). The institution-level characteristics included as independent variables in this analysis were retrieved directly from the IPEDS Feedback Reports and the data warehouse using the unique OPEID numbers assigned to each institution.

The United States Constitution mandates that the Census Bureau collect and report population census data, which is used as the basis for appropriating legislative seats in the House of Representatives and defining government districts (United States Census Bureau, 2017). Additionally, the Census reports population and wage data at the state, national, and county, and city level. The Median Annual Income data included as an independent variable in this study was retrieved directly from the United States Census Bureau online data warehouse. The United States Bureau of Labor Statistics (BLS) reports economic indicators related to workforce and employment. The countylevel unemployment rates were retrieved from the Bureau of Labor Statistics online data warehouse (U.S. Bureau of Labor Statistics, 2017). 
The development of individual-level and institution-level data sets is outlined later in this chapter.

\section{Operationalization of Study Variables}

The unit of analysis in this study is the federal student loan recipients who attended a two-year public institution in the state of Kentucky and entered into repayment on federal student loans in federal fiscal year 2013. There is one dependent variable: a measure of the borrower's federal student loan default status. With regard to the present study this variable is binary and the two potential outcomes are (0) indicating no presence of default during the three-year cohort default rate monitoring window and (1) indicating at least one instance of default on federal student loans during the DOE cohort default monitoring timeframe, according to National Student Loan Data System (NSLDS) records as indicated in the Loan Record Detail Report (LRDR). The binary measure reflects the Department of Education's current methodology for tracking federal student loan default among postsecondary institutions. However, in reality, default may be measured in non-binary terms, as default varies in terms of length of time in default and total debt sum in default.

This study incorporates individual-level and institution-level independent variables measured on categorical and continuous scales. A detailed description of the study variables, definitions, and variable measurement follows.

As outlined in Table 4, individual-level variables are grouped into five categories: (1) demographic factors, (2) college readiness factors, (3) academic factors, (4) financial aid factors, and (5) completion and transfer factors. There are three variables related to students' demographic characteristics: gender, age, and race/ethnicity. Three variables 
measure college readiness: high school graduation status (GED versus diploma), whether the borrower required Reading, and whether the borrower required Developmental Math (and associated need level - low, medium, or high). The academic variables include the student's cumulative Grade Point Average, the number of credits the student accumulated in the first semester, and the number of terms the student was enrolled in any college in the system. Additionally, an indication of the borrower's total sum of student loan debt and Pell eligibility status and dependency status are included to measure the effects of key financial aid variables. With regard to completion and transfer, this study includes a measure of degree attainment from a KCTCS institution (Certificate or Diploma, Associate in Applied Science, or Associate in Arts or Science) and an indication of whether the borrower transferred to four-year postsecondary institution prior to entering repayment.

A definition, measurement scale, and data source for each individual-level variable is delineated in Table 4. All individual-level variables are obtained from the Kentucky Community and Technical College System Decision Support System (DSS). 
Table 4

Individual-Level Independent Variable Definitions, Measurement, and Data Source

\begin{tabular}{|c|c|c|c|}
\hline Variable & Definition & Measurement & $\begin{array}{l}\text { Data } \\
\text { Source } \\
\end{array}$ \\
\hline \multicolumn{4}{|l|}{ Demographic Factors } \\
\hline Gender & $\begin{array}{l}\text { Self-reported Gender, as } \\
\text { indicated on KCTCS } \\
\text { Application }\end{array}$ & $\begin{array}{l}\text { Categorical } \\
\text { (0) Female } \\
\text { (1) Male } \\
\text { (2) Undisclosed } \\
\text { [dummy coded] }\end{array}$ & $\begin{array}{l}\text { KCTCS } \\
\text { DSS }\end{array}$ \\
\hline Age & $\begin{array}{l}\text { Age, calculated from date } \\
\text { of birth, as indicated on } \\
\text { KCTCS Application }\end{array}$ & Continuous & $\begin{array}{l}\text { KCTCS } \\
\text { DSS }\end{array}$ \\
\hline Pre-College Academ & $\begin{array}{l}\text { Self-reported } \\
\text { race/ethnicity, as } \\
\text { indicated on KCTCS } \\
\text { Application }\end{array}$ & $\begin{array}{l}\text { Categorical } \\
\text { (0) White } \\
\text { (1) Black/African American } \\
\text { (2) Hispanic/Latino/a } \\
\text { (3) Asian } \\
\text { (4) Other } \\
\text { [dummy coded] }\end{array}$ & $\begin{array}{l}\text { KCTCS } \\
\text { DSS }\end{array}$ \\
\hline $\begin{array}{l}\text { High School } \\
\text { Graduation Status }\end{array}$ & $\begin{array}{l}\text { Indicates whether a } \\
\text { borrower received a } \\
\text { diploma or GED, as } \\
\text { indicated in KCTCS } \\
\text { academic records }\end{array}$ & $\begin{array}{l}\text { Categorical } \\
\text { (0) High School Diploma } \\
\text { (1) GED }\end{array}$ & $\begin{array}{l}\text { KCTCS } \\
\text { DSS }\end{array}$ \\
\hline $\begin{array}{l}\text { Placement Test } \\
\text { Score: Reading }\end{array}$ & $\begin{array}{l}\text { Indicates whether the } \\
\text { borrowers required } \\
\text { developmental Reading }\end{array}$ & $\begin{array}{l}\text { Categorical } \\
\text { (0) No Reading Required } \\
\text { (1) Reading Required }\end{array}$ & $\begin{array}{l}\text { KCTCS } \\
\text { DSS }\end{array}$ \\
\hline $\begin{array}{l}\text { Placement Test } \\
\text { Scores: Math }\end{array}$ & $\begin{array}{l}\text { Indicates whether the } \\
\text { borrower required } \\
\text { developmental education } \\
\text { in Math and associated } \\
\text { level (Math levels as } \\
\text { defined for Voluntary } \\
\text { Framework of } \\
\text { Accountability reporting) }\end{array}$ & $\begin{array}{l}\text { Categorical } \\
\begin{array}{l}\text { (0) No Dev Math Need } \\
\text { (1) Low Dev Math Need - } 1 \\
\text { level below college } \\
\text { (2) Med Dev Math Need - } 2 \\
\text { levels below college } \\
\text { (3) High Dev Math Need - } 3 \\
\text { levels below college }\end{array} \\
\text { [dummy coded] }\end{array}$ & $\begin{array}{l}\text { KCTCS } \\
\text { DSS }\end{array}$ \\
\hline Academic Factors & & & \\
\hline $\begin{array}{l}\text { Number of Credits } \\
\text { Passed }\end{array}$ & $\begin{array}{l}\text { Indicates the number of } \\
\text { credits successfully } \\
\text { attained }\end{array}$ & $\begin{array}{l}\text { Continuous } \\
0-\end{array}$ & $\begin{array}{l}\text { KCTCS } \\
\text { DSS }\end{array}$ \\
\hline $\begin{array}{l}\text { College Grade Point } \\
\text { Average }\end{array}$ & Grade Point Average & $\begin{array}{l}\text { Continuous } \\
0-4.0\end{array}$ & $\begin{array}{l}\text { KCTCS } \\
\text { DSS }\end{array}$ \\
\hline
\end{tabular}




\begin{tabular}{|c|c|c|c|}
\hline Variable & Definition & Measurement & $\begin{array}{l}\text { Data } \\
\text { Source }\end{array}$ \\
\hline $\begin{array}{l}\text { Number of Terms } \\
\text { Enrolled }\end{array}$ & $\begin{array}{l}\text { Indicates the number of } \\
\text { terms enrolled in a } \\
\text { KCTCS institution }\end{array}$ & $\begin{array}{l}\text { Continuous } \\
0-\end{array}$ & $\begin{array}{l}\text { KCTCS } \\
\text { DSS }\end{array}$ \\
\hline \multicolumn{4}{|l|}{ Financial Aid Factors } \\
\hline Pell Grant Eligibility & $\begin{array}{l}\text { Borrower's eligibility } \\
\text { status for income-based } \\
\text { Pell Grant, latest tern } \\
\text { enrolled }\end{array}$ & $\begin{array}{l}\text { Categorical } \\
\text { (0) No not eligible } \\
\text { (1) Yes eligible }\end{array}$ & $\begin{array}{l}\text { KCTCS } \\
\text { DSS }\end{array}$ \\
\hline $\begin{array}{l}\text { Aggregate Federal } \\
\text { Student Loan } \\
\text { Amount }\end{array}$ & $\begin{array}{l}\text { Borrower's aggregate sum } \\
\text { of student loan debt from } \\
\text { KCTCS }\end{array}$ & $\begin{array}{l}\text { Continuous } \\
\$ 0-\end{array}$ & $\begin{array}{l}\text { KCTCS } \\
\text { DSS }\end{array}$ \\
\hline Dependency Status & $\begin{array}{l}\text { Financial aid dependency } \\
\text { status, as indicated in } \\
\text { most recent KCTCS } \\
\text { financial aid records for } \\
\text { last year enrolled }\end{array}$ & $\begin{array}{l}\text { Categorical } \\
\text { (0) Dependent } \\
\text { (1) Independent }\end{array}$ & $\begin{array}{l}\text { KCTCS } \\
\text { DSS }\end{array}$ \\
\hline
\end{tabular}

Completion and Transfer Factors

\begin{tabular}{llcl}
\hline Degree Completion & Highest Degree Awarded & Categorical & KCTCS \\
& & (0) No Credential & (1) Certificate/Diploma \\
& (2) Associate in Arts/Science & \\
& (3) Associate in Applied & \\
& & Science & \\
& & [dummy coded] & \\
$\begin{array}{l}\text { Transfer to Four- } \\
\text { Year }\end{array}$ & $\begin{array}{l}\text { Indication of whether the } \\
\text { borrower transferred to a } \\
\text { four-year institution }\end{array}$ & Categorical & KCTCS \\
& & (1) Yes & $\begin{array}{l}\text { DSS } \\
\text { (National }\end{array}$ \\
& & & Student \\
& & Clearinghou \\
& & & se)
\end{tabular}

In addition to individual-level variables, this study incorporates variables that are measured at the institution-level. The institution-level variables are delineated in Table 5 and include institutional size composition and locale factors, institutional performance factors, institutional spending factors, and macroeconomic factors. As previously 
indicated, the county-level variables will be based on the home campus of the federal student loan recipient.

Table 5

Institution-Level Independent Variables: Definition, Measurement, and Data Source

\begin{tabular}{|c|c|c|c|}
\hline Variable & Definition & Measurement & $\begin{array}{l}\text { Data } \\
\text { Source }\end{array}$ \\
\hline \multicolumn{4}{|c|}{ Institution Size, Composition, and Locale Factors } \\
\hline Campus Size & FTE, Fall 2012 & $\begin{array}{l}\text { Continuous/Interval } \\
1-20,000\end{array}$ & IPEDS \\
\hline Campus Setting & Campus Setting & $\begin{array}{l}\text { Categorical } \\
\text { (0) City } \\
\text { (1) Rural } \\
\text { (2) Town } \\
\text { (3) Suburb } \\
\text { [dummy coded] }\end{array}$ & IPEDS \\
\hline Appalachian Region & $\begin{array}{l}\text { Indicates whether the } \\
\text { institution is located in } \\
\text { Appalachia }\end{array}$ & $\begin{array}{l}\text { Categorical } \\
\begin{aligned}(0) & \text { No } \\
(1) & \text { Yes }\end{aligned}\end{array}$ & \\
\hline Percent Pell & $\begin{array}{l}\text { Percent of Students } \\
\text { Received Pell }\end{array}$ & $\begin{array}{l}\text { Continuous } \\
0-100 \%\end{array}$ & IPEDS \\
\hline Percent Loans & $\begin{array}{l}\text { Percent of Students } \\
\text { Awarded Loans }\end{array}$ & $\begin{array}{l}\text { Continuous } \\
0-100 \%\end{array}$ & IPEDS \\
\hline \multicolumn{4}{|c|}{ Institution Performance Factors } \\
\hline $\begin{array}{l}\text { First-Year Student } \\
\text { Retention }\end{array}$ & $\begin{array}{l}\text { Percent of full-time, first- } \\
\text { time, credential-seeking } \\
\text { students enrolled in a } \\
\text { given fall term, retained to } \\
\text { the following fall term }\end{array}$ & $\begin{array}{l}\text { Continuous } \\
0-100 \%\end{array}$ & IPEDS \\
\hline Graduation Rate & $\begin{array}{l}\text { Percent of full-time, first- } \\
\text { time credential seeking } \\
\text { students who graduate } \\
\text { within } 150 \% \text { of time ( } 3 \\
\text { years) }\end{array}$ & $\begin{array}{l}\text { Continuous } \\
0-100 \%\end{array}$ & IPEDS \\
\hline
\end{tabular}




\begin{tabular}{|c|c|c|c|}
\hline Variable & Definition & Measurement & $\begin{array}{l}\text { Data } \\
\text { Source }\end{array}$ \\
\hline \multicolumn{4}{|c|}{ Institutional Spending Factors } \\
\hline Instruction & $\begin{array}{l}\text { Reflects dollars spent on } \\
\text { instruction per FTE, } \\
\text { Fiscal Year } 2012\end{array}$ & $\begin{array}{l}\text { Continuous } \\
0-\$ 10,000\end{array}$ & IPEDS \\
\hline Academic Support & $\begin{array}{l}\text { Reflects dollars spent on } \\
\text { academic support per } \\
\text { FTE, Fiscal Year } 2012\end{array}$ & $\begin{array}{l}\text { Continuous } \\
0-\$ 10,000\end{array}$ & IPEDS \\
\hline \multicolumn{4}{|c|}{ Macroeconomic Factors } \\
\hline Unemployment Rate & $\begin{array}{l}\text { Unemployment rate for } \\
\text { the county in which the } \\
\text { main campus of the } \\
\text { institution is situated, for } \\
2012\end{array}$ & $\begin{array}{l}\text { Continuous/Interval } \\
0-100 \%\end{array}$ & $\begin{array}{l}\text { Bureau of } \\
\text { Labor } \\
\text { Statistics }\end{array}$ \\
\hline $\begin{array}{l}\text { Median Annual } \\
\text { Income }\end{array}$ & $\begin{array}{l}\text { Median Annual Income } \\
\text { for the county in which } \\
\text { the main campus of the } \\
\text { institution is situated, for } \\
2012\end{array}$ & $\begin{array}{l}\text { Continuous/Ratio } \\
\$ 0-\end{array}$ & $\begin{array}{l}\text { Census } \\
\text { Bureau }\end{array}$ \\
\hline
\end{tabular}

\section{Analytic Technique}

This study was designed to address various adaptations of one underlying research question: What individual and institutional factors are related to federal student loan default among borrowers within a statewide system of two-year public postsecondary institutions? The research questions are addressed by examining the effects of numerous explanatory (independent) variables on one criterion (dependent) variable. The dependent variable is discrete and binary, meaning there are only two potential outcomes (“default" or "no default").

This study aims to measure direction and magnitude of the effect of each explanatory variable on the criterion variable in addition to the relative influence of each explanatory variable while simultaneously controlling for all other explanatory variables in the model (Osborne, 2016). When addressing this type of question with a binary 
outcome variable a logistic regression is the appropriate technique. The logistic regression equation calculates the natural logarithm of the predicted odds of the dependent variable, a distinction from OLS regression that addresses conceptual problems that arise when a binary variable is treated as continuous variable (Osborne, 2016). A standard logistic regression analysis presumes the variables are independent, meaning they are not related to each other (Osborne, 2014); however, because this study explores a set of borrowers grouped by college campus attended, by design this study violates the assumption of independence (Cohen, 2008). An underlying assumption of most statistical tests is that units are completely independent of one another. When variables are grouped or nested - for example, when a study examines students grouped in classrooms or schools - this violates the assumption of independence, as there is inherent correlation among grouped variables.

Hierarchical Linear Modeling (HLM) is a technique designed to account for and estimate statistical variance when there are multiple levels of an independent variable present (Raudenbush \& Bryk, 2002; Robson \& Pevalin, 2016). HLM is able to appropriate model nested variables by assigning error terms based on group membership, and is therefore a necessary function in order to ensure accurate estimation when working with multilevel independent variables (Gelman \& Hill, 2007; Raudenbush \& Bryk, 2002; Robson \& Pevalin, 2016). HLM offers many advantages over alternative techniques to address multilevel variables (i.e., aggregation and disaggregation); with HLM effects can be partitioned at each level of the independent variable and cross-level interactions can be assessed (Raudenbush \& Bryk, 2002; Robson \& Pevalin, 2016). Due to these advantageous nature of the statistical test and the propensity toward nested variables in 
higher education research (i.e., students in institutions) the method is growing in use among higher education research (Niehaus, Campbell, Inkelas, 2014). A standard HLM analysis is equipped to explore linear relationships between a continuous dependent variable and a set of independent variables; therefore, when the dependent variable is dichotomous (as is the case in the present study) an extension of HLM must be employed (Snijders \& Bosker, 2012). A Hierarchical Generalized Linear Model (HGLM) handles this variation by transforming the data to ensure potential outcome values are constrained to the appropriate outcomes by replaying the normal sampling model with a binomial sampling model (Bernoulli distribution) and replacing the identity link function with a logit-transformed link function (Raudenbush \& Bryk, 2002). Consequently, predicted logged-odds and conditional probabilities can be identified by converting outcome statistics, similar to results of a logistic regression analysis. Thus, HGLM was selected as the analysis for this study.

\section{Data Analysis}

\section{Individual-Level (Level One) Dataset Development}

The Department of Education Loan Record Detail Report (LRDR) file is provided to Title IV postsecondary institutions annually and contains details that reveal the basis for calculating the institution's cohort default rate (CDR). In this study, LRDR files served as the reference document to identify borrowers included in the Fiscal Year 2013 CDR for each of the sixteen Kentucky Community and Technical College System (KCTCS) institutions. A Social Security Number (SSN) and default status indicator ('default' or 'no default') for each borrower was extracted from each of the sixteen LRDR reports, in addition to the Office of Postsecondary Education Identification 
(OPEID) code to identify the corresponding institution. SSNs were matched to KCTCS institutional records to identify each borrower's KCTCS student identification number. The KCTCS student identification number was then used to retrieve institutional records for each borrower (including demographic, academic, and financial aid records). Using the Student ID and SSN as matching variables, institutional records were merged with the LRDR default records to construct a dataset containing all level-one data.

Notably, for a small number of cases a KCTCS student could not be found for an SSN and was therefore excluded $(n=19)$, some LRDR reports contained duplicative SSNs which were also removed $(n=36)$, and in a smaller number of cases KCTCS academic records could not be identified based on the student identification number indicated by the match $(n=4)$. In cases where borrowers attended more than one KCTCS institution, the borrower was categorized to align with the last KCTCS institution attended and other duplicate cases were removed $(n=445)$ (note: cumulative academic and financial aid data such as number terms enrolled and total loans awarded reflects collective totals for all KCTCS institutions attended). After matching and removing duplicate and SSNs non-matched data, the dataset resulted in a total of 25,370 individual-level student records.

\section{Institution-Level (Level Two) Dataset Development}

A level-two dataset was constructed with institutional variables retrieved from the National Center for Education Statistics IPEDS Feedback Report for each of the sixteen KCTCS institutions, the Census Bureau, and the Department of Bureau and Labor Statistics. IPEDS data was retrieved by using the OPEID code included on the 
postsecondary institution's LRDR report. The Census Bureau and BLS data were retrieved for the Kentucky county in which the institution is situated.

The de-identified dataset constructed for the study was uploaded to SPSS (Statistical Package for the Social Sciences) Version 22.0. A case number was computed for each variable. The dichotomous dependent variable was coded to indicate whether the borrower had defaulted during the DOE three-year monitoring window ("0" for no and "1" for yes). Next, non-dichotomous categorical variables were "dummy coded," which refers to the act of transforming one non-dichotomous categorical variable into a series of dichotomous categorical variables (Cohen, 2008; Osborne, 2014; Wagner, 2017). As recommended by Osborne (2016), continuous variables were converted to zscores: adjusting continuous independent variables to a standard deviation scale allows relative effects to be more easily interpreted. To inspect for multicollinearity, a zeroorder correlation matrix containing each of the continuous variables was inspected. The correlation matrix revealed that two variables - Credits Passed and Terms Enrolled were highly correlated $(\mathrm{r}=.817)$, therefore, number of terms enrolled was dropped from the regression modeling to reduce redundancy. Level 2 descriptive statistics revealed that Percent Pell and Percent Loans were correlated $(\mathrm{r}=.817)$ and Unemployment Rate and Median Annual Income were correlated $(r=.763)$, therefore only Percent of Students Awarded Pell and Unemployment Rate were included in the HGLM analysis.

In accordance with best practices, the data were inspected for missing values. Only two cases contained missing values. Due to the very small number of missing cases and the capacity of HLM to handle level-one cases through listwise deletion, the two cases with missing data were not manipulated. As recommended by Osborne (2016), 
continuous independent variables (Age, Credits Passed, Cumulative GPA, and Loans) were converted to standard normal distribution (z-scores with a mean of zero and a standard deviation of one) to aid in comparing relative outcomes to aid in assessing for curvilinear effects and ease in comparing outcomes.

As a final step prior to running the HGLM, the researcher executed a descriptive analysis, in which means and standard deviations were derived for each study variable, reported in aggregate and disaggregated by default status group (defaulter versus nondefaulters). For categorical variables, this data conveys default rates relative to categorical group membership (i.e., default rates for males versus females). For continuous variables, this data conveys means for each variable, relative to default status (i.e., average student loan debt sum for defaulters versus non-defaulters). After completing the descriptive analysis, the data was uploaded to HLM 7.01 for Windows (Raudenbush, Bryk, \& Congdon, 2013).

\section{Limitations}

In any study, decisions about research design produce corresponding limitations. This study employs a non-experimental correlational research design, a limitation of which is that the method does not facilitate the identification of causal inferences or claims (Creswell, 2012). Therefore, this study does not aim to uncover the "causes" of student loan default among the sample of borrowers, only emergent patterns related to the strength and direction of association among variables (Creswell, 2012). Further, this study employs a convenience sample of one state system of two-year public institutions. Therefore, the extent to which these findings apply to other settings may be related to economic, political, and national contexts. 
Additionally, during the data analysis phase, several necessary choices created additional study limitations. The study analyzes borrowers who entered repayment on their student loans between October 2012 and September 2013. In order to align institution-level variables with the timeframe in which loan recipients were enrolled at the College, the researcher retrieved study variables for Academic Year 2011-2012. However, some loan recipients (such as those who transferred to another postsecondary institution or deferred repayment) may not have been enrolled at the institution at the time in which these performance characteristics applied, ${ }^{8}$ which presents some degree of threat to internal validity. Relatedly, wage and economic indicators (median annual income and unemployment rate) are associated with the location of the institution/campus at which the borrower procured a student loan. This fact poses a similar threat to internal validity, in that the borrower may reside in a county with a higher or lower unemployment and/or median annual wage. Finally, as noted in the scope and delimitations section, the scope of this study is limited to data that is accessible to college administrators and stored in an institutional data warehouse; thus, potentially relevant factors such as employment, wages, and geographic location are not included in this analysis.

Another limitation is related to the sample size for the study. As there are only sixteen institutions in the Kentucky Community and Technical College System, the leveltwo sample size equated to 16 . There is some debate over the minimum sample size allotted for a two-level design. Some simulation studies indicate that small level-two

\footnotetext{
${ }^{8}$ For example, a borrower could have exited the KCTCS institution, directly transferred to a four-year institution, entered educational loan deferment for two additional years, and entered repayment upon sixmonth exit from the four-year institution.
} 
sample sizes may lead to estimation bias and reduction in power (Maas \& Hox, 2005;

Niehaus, Campbell, \& Inkelas, 2014; Snijders, 2005) while others purport that regardless of sample size, multilevel designs should employ hierarchical analyses (Gelman \& Hill, 2007; Robson \& Pevalin, 2016). Therefore, some degree of caution should be given in interpreting institution-level variables.

Finally, though cross-level interactions are of potential interest, the scope of the current study is focused solely on main effects.

\section{Assumptions}

The primary underlying assumption of this study is that the Department of Education, institutional academic and financial aid records, institutional characteristics, and U.S. census data reflect an accurate depiction of reality. This assumption leads to limitations surrounding internal validity, as there is always the potential for error.

\section{Ethics}

Prior to the study, the Kentucky Community and Technical College System (KCTCS) Human Subjects Review Board (HSRB) authorized all data collection and data analysis procedures delineated in this chapter. The HSRB application and a letter from the Chancellor of KCTCS in which permission to conduct the study is documented is located in the appendix. An Inter-University Agreement Institutional Review Board was also approved.

This study necessitates the examination of archival data warehouse records housed by KCTCS or provided to the KCTCS colleges by the Department of Education. These records contain sensitive and identifiable individual-level data. Therefore, measured action was taken to ensure that the files were stored in a protected and secure 
location. Each file associated with the study was encrypted and saved on a secured KCTCS server and was not be copied, duplicated, or saved to any other location. Only the Principal Investigator possessed access to files containing identifiable student data. All data is reported in aggregate format and no student-level identifiable data is included in published articles or reports. The measures indicated above ensured that data remains secure; therefore, minimal to no risk to study participants is anticipated.

\section{Summary}

In conclusion, this aim of this study is to document factors associated with student loan default among borrowers who attend community college. As delineated in Chapter 3 , this study aims to address default by employing logistic regression and hierarchal linear modeling to assess the relative effect of individual-level and institution-level variables on student loan default risk. 


\section{CHAPTER IV}

\section{RESULTS}

This study employed a Hierarchical Generalized Linear Model (HGLM) to explore individual-level and institution-level factors associated with student loan default among a sample of federal student loan recipients who attended a postsecondary institution in a statewide system of two-year community and technical colleges. This chapter presents descriptive statistics for the sample of borrowers and institutions included in the study. Followed is a summary of the results of the HGLM analysis, organized by study research question.

\section{Sample Characteristics}

\section{Individual-Level Sample Characteristics}

The final sample comprised of 25,370 student loan recipients who obtained a federal student loan(s) from a two-year postsecondary institution in Kentucky and entered repayment on the loan(s) in Fiscal Year 2013. The majority of the sample $(63.6 \%)$ identify as female (Table 6). The age of record at the time at which the borrower entered repayment ranged from 17 to 76 , with a mean age equal to $29.7(\mathrm{SD}=9.1)$. About $77 \%$ of borrowers identify as White, $17 \%$ as Black/African American, $2.1 \%$ as Hispanic/Latino/a, $0.5 \%$ as Asian, and $3.4 \%$ as an other race/ethnicity. 
Table 6

Sample Characteristics: Demographic Variables

\begin{tabular}{lll}
\hline Gender & n & Percent \\
Female* & 16,139 & $63.6 \%$ \\
Male & 9,144 & $36.0 \%$ \\
Undisclosed & 87 & $0.3 \%$ \\
Race/Ethnicity & & \\
White* & 19,548 & $77.1 \%$ \\
Black/African Am. & 4,304 & $17.0 \%$ \\
Hispanic/Latino/a & 542 & $2.1 \%$ \\
Asian & 121 & $0.5 \%$ \\
Other & 855 & $3.4 \%$ \\
& & \\
\hline Age & $\mathbf{n}$ & Mean (SD) \\
*Reference Category & 25,370 & \\
\end{tabular}

Table 7 presents an overview of the sample with regard to college readiness and academic outcomes in college. Nearly $16 \%$ of the sample were GED recipients. A significant proportion of the borrowers in the sample required a developmental/remedial education course prior to enrolling in a college-level class: as indicated in Table 7, 38.0\% of the sample required a developmental reading course and $69.7 \%$ required one or more courses in developmental math. (Math need is "undetermined" for roughly $10 \%$ of the students, signaling the student was enrolled in a program in which a math requirement was not mandatory). Borrowers in the sample were enrolled in 5.7 terms on average (SD $=3.8)$ and earned an average of 35 credit hours $(\mathrm{SD}=33)$. The cumulative GPA for the total sample was $2.01(\mathrm{SD}=1.21)$. 
Table 7

Sample Characteristics: College Readiness and Academic Variables

\begin{tabular}{lll}
\hline College Readiness Variables & n & Percent \\
\hline Did not earn GED* & 21,354 & $84.2 \%$ \\
Earned GED & 4,016 & $15.8 \%$ \\
Did not Require Developmental Reading* & 15,741 & $62.0 \%$ \\
Required Developmental Reading & 9,629 & $38.0 \%$ \\
Developmental Math & & \\
$\quad$ None Required* & 5,094 & $20.1 \%$ \\
$\quad$ Low Need & 4,596 & $18.1 \%$ \\
$\quad$ Medium Need & 9,164 & $36.1 \%$ \\
$\quad$ High Need & 3,922 & $15.5 \%$ \\
$\quad$ Need Undetermined & 2,594 & $10.2 \%$ \\
& & \\
\hline Academic Variables & $\mathbf{n}$ & $\mathbf{M}(\mathbf{S D})$ \\
\hline Number of Credits Passed & 25,370 & $35(33)$ \\
Cumulative GPA & 25,370 & $2.01(1.21)$ \\
Terms Enrolled & 25,370 & $5.7(3.8)$ \\
*Reference Category & &
\end{tabular}

On average, borrowers accumulated a total cumulative federal student loan balance equal to roughly $\$ 10,658$ ( $\mathrm{SD}=\$ 8,764$ ) from the institution(s) in the system. The majority of borrowers in the sample (81\%) were eligible for the income-based Pell Grant (according to most recent FAFSA data). About $75 \%$ of the loan recipients in the sample were considered independent from a financial aid perspective. 
Table 8

Sample Characteristics: Financial Aid Variables

\begin{tabular}{lll}
\hline Financial Aid Variables & $\mathbf{n}$ & Percent \\
\hline Not Pell-Eligible* & 4,853 & $19.1 \%$ \\
Pell-Eligible & 20,517 & $80.9 \%$ \\
Dependent* & 6,166 & $24.3 \%$ \\
Independent & 19,136 & $75.4 \%$ \\
Dependency Status Undetermined & 66 & $0.3 \%$ \\
& & \\
\hline & $\mathbf{n}$ & $\mathbf{M}(\mathbf{S D})$ \\
\hline Total KCTCS Loan Debt & 25,368 & $\$ 10,658.33(\$ 8764.12)$
\end{tabular}

*Reference Category

By the date at which the cohort entered repayment on federal student loans, $11.7 \%$ of borrowers in the sample attained an Associate in Applied Science, $6.2 \%$ attained an Associate in Arts or Science, and 20.6\% earned a certificate or diploma. $10.4 \%$ of the sample transferred to a four-year institution prior to the beginning of federal cohort year 2013 .

Table 9

Sample Characteristics: Completion and Transfer Variables

\begin{tabular}{cll}
\hline Transfer and Completion & n & Percent \\
\hline Earned Associate in Applied Science & 2,969 & $11.7 \%$ \\
Earned Associate in Arts/Science & 1,583 & $6.2 \%$ \\
Earned Certificate or Diploma & 5,227 & $20.6 \%$ \\
Transferred to 4-Year Institution & 2,648 & $10.4 \%$
\end{tabular}


Table 10

Sample Characteristics: Student Loan Default Status

\begin{tabular}{lll}
\hline Default & N & Percent \\
\hline Default & 6,729 & $26.5 \%$ \\
No Default & 18,641 & $73.5 \%$
\end{tabular}

Overall, $26.5 \%$ of borrowers in the sample $(n=6,729)$ defaulted on their loans at least once during the U.S. Department of Education's three-year cohort default rate monitoring window. Prior to conducting the HGLM, default rates for continuous variables means and SD were computed based upon default status group membership (Table 11) and categorical variables were calculated for each variable group (Table 12).

Table 11

Descriptive Statistics by Default Status, Individual-Level Continuous Variables

\begin{tabular}{lcc}
\hline & Default & No Default \\
M (SD) & M (SD) \\
\hline
\end{tabular}

\section{Background Demographic Variables}

Age

$29.5(8.7)$

$29.7(9.3)$

Financial Aid Variables

Total KCTCS Loan Debt

Academic Variables

Number of Credits Passed

$\$ 8,418(\$ 7,207) \quad \$ 11,467(\$ 9,129)$

Number of Terms Enrolled

21 (26)

40 (34)

Cumulative GPA

$6.2(3.9)$

1.38 (1.17)

$2.24(1.15)$ 
Table 12

Descriptive Statistics by Default Status, Individual-Level Categorical Variables

\begin{tabular}{|c|c|c|c|c|c|}
\hline & \multirow[t]{2}{*}{ Total } & \multicolumn{2}{|c|}{ Default } & \multicolumn{2}{|c|}{ No Default } \\
\hline & & $\mathrm{n}$ & $\%$ & $\mathrm{n}$ & $\%$ \\
\hline Overall Default Rate & 25,370 & 6,729 & $26.5 \%$ & 18,641 & $73.5 \%$ \\
\hline \multicolumn{6}{|l|}{ Background Demographic Variables } \\
\hline \multicolumn{6}{|l|}{ Gender } \\
\hline Female & 16,139 & 3,635 & $22.5 \%$ & 12,504 & $77.5 \%$ \\
\hline Male & 9,144 & 3,059 & $33.5 \%$ & 6,085 & $66.5 \%$ \\
\hline Undisclosed & 87 & 35 & $40.2 \%$ & 52 & $59.8 \%$ \\
\hline \multicolumn{6}{|l|}{ Race Ethnicity } \\
\hline White & 19,548 & 5,044 & $25.8 \%$ & 14,504 & $74.2 \%$ \\
\hline Black/African American & 4,304 & 1,308 & $30.4 \%$ & 2,996 & $69.6 \%$ \\
\hline Hispanic/Latino/a & 542 & 135 & $24.9 \%$ & 407 & $75.1 \%$ \\
\hline Asian & 121 & 15 & $12.4 \%$ & 106 & $87.6 \%$ \\
\hline Other & 855 & 227 & $26.5 \%$ & 628 & $73.5 \%$ \\
\hline \multicolumn{6}{|l|}{ College Readiness Variables } \\
\hline Did not earn GED & 21,354 & 5,111 & $23.9 \%$ & 16,243 & $76.1 \%$ \\
\hline Earned GED & 4,016 & 1,618 & $40.3 \%$ & 2,398 & $59.7 \%$ \\
\hline Did not Require Developmental Reading & 15,741 & 3,477 & $22.1 \%$ & 12,264 & $77.9 \%$ \\
\hline Required Developmental Reading & 9,629 & 3,252 & $33.8 \%$ & 6,377 & $66.2 \%$ \\
\hline \multicolumn{6}{|l|}{ Developmental Math } \\
\hline None Required & 5,094 & 874 & $17.2 \%$ & 4,220 & $82.8 \%$ \\
\hline Low Need & 4,596 & 1,076 & $23.4 \%$ & 3,520 & $76.6 \%$ \\
\hline Medium Need & 9,164 & 2,848 & $31.1 \%$ & 6,316 & $68.9 \%$ \\
\hline High Need & 3,922 & 1,425 & $36.3 \%$ & 2,497 & $63.7 \%$ \\
\hline Need Undetermined & 2,594 & 506 & $19.5 \%$ & 2,088 & $80.5 \%$ \\
\hline \multicolumn{6}{|l|}{ Financial Aid Variables } \\
\hline Not Pell-Eligible & 4,853 & 484 & $10.0 \%$ & 4,369 & $90.0 \%$ \\
\hline Pell-Eligible & 20,517 & 6,245 & $30.4 \%$ & 14,272 & $69.6 \%$ \\
\hline Dependent & 6,166 & 1,209 & $19.6 \%$ & 4,957 & $80.4 \%$ \\
\hline Independent & 19,136 & 5,507 & $28.8 \%$ & 13,629 & $71.2 \%$ \\
\hline Dependency Status Undetermined & 66 & 13 & $19.7 \%$ & 53 & $80.3 \%$ \\
\hline \multicolumn{6}{|l|}{ Completion and Transfer Variables } \\
\hline Earned Associate in Applied Science & 2,969 & 230 & $7.7 \%$ & 2739 & $92.3 \%$ \\
\hline Earned Associate in Arts/Science & 1,583 & 122 & $7.7 \%$ & 1461 & $92.3 \%$ \\
\hline Earned Certificate or Diploma & 5,227 & 801 & $15.3 \%$ & 4426 & $84.7 \%$ \\
\hline Transferred to 4-Year & 2,648 & 334 & $12.6 \%$ & 2314 & $87.4 \%$ \\
\hline
\end{tabular}




\section{Institution-Level Sample Characteristics}

The federal student loan recipients included in the study sample were affiliated with at least one of sixteen postsecondary institutions in one statewide community and technical college system. Following is a descriptive overview of the institution-level variables for the sixteen institutions included in the sample. The sixteen institutions vary in terms of locale: according to IPEDS Campus Setting descriptions, four institutions are considered "City" locale, four are considered "Rural" locale, and 8 are considered "Town/Suburb" locale (IPEDS, 2013). Three institutions are located in the Appalachian region. As illustrated in Table 13, the institutions also vary in terms of enrollment size: Full-Time Equivalency (FTE) ranged from 1,386 to 9,354, with a mean FTE equal to $3,276(\mathrm{SD}=2,287)$.

IPEDS first-year retention rates for the sixteen institutions ranged between $35 \%$ and $67 \%$. Official graduation rates (150\% of time) ranged between $13 \%$ and $39 \%$. On average, the student populations were $45.0 \%$ Pell-eligible (ranging between $33 \%$ and $61 \%$ ) with $32.6 \%$ of students utilizing student loans in a given year (ranging between $19 \%$ to $52 \%)$. On average, institutions spent $\$ 4,856(\mathrm{SD}=\$ 920)$ on Instructional Expenses per FTE enrollment and \$822 on Academic Support Expenses per FTE Enrollment $(\mathrm{SD}=\$ 322)$.

The macroeconomic factors included in this study - Median Household Income and Unemployment Rates - are measured at the county in which the institution is situated and were retrieved from the U.S. Census Bureau American FactFinder and the U.S. Bureau of Labor Statistics (BLS), respectively. The regional economic characteristics reflect 2012 figures to align with the year the borrowers in the sample entered repayment 
on federal student loans. Median Annual Income for 2012 ranged between $\$ 26,758$ and $\$ 67,125$ with a mean of $\$ 41,617(\mathrm{SD}=\$ 9,576)$. The Unemployment Rates for October 2012 ranged between $5.5 \%$ and $14.4 \%$. 
Table 13

Descriptive Statistics for Institutions, Level-Two Continuous Variables

\begin{tabular}{lllll}
\hline & Minimum & Maximum & M & SD \\
\hline Size, Composition, and Locale & & & & \\
\hline FTE & 1,386 & 9,354 & 3,726 & 2287 \\
Percent Pell & $33 \%$ & $61 \%$ & $45.0 \%$ & $8.1 \%$ \\
Percent Loans & $19 \%$ & $52 \%$ & $32.6 \%$ & $10.2 \%$ \\
\hline Institutional Performance & & & & \\
\hline First-Year Retention Rate & $35 \%$ & $67 \%$ & $56.9 \%$ & $7.2 \%$ \\
Official Graduation Rate & $13 \%$ & $39 \%$ & $26.6 \%$ & $7.9 \%$ \\
\hline Institutional Spending & & & & \\
\hline Instruction & $\$ 3732$ & $\$ 6892$ & $\$ 4856.69$ & $\$ 920.83$ \\
Academic & $\$ 334$ & $\$ 1405$ & $\$ 822.63$ & $\$ 322.05$ \\
\hline Macroeconomic Variables & \multicolumn{5}{l}{$\$$} \\
\hline Median Household Income & $\$ 26,758$ & $\$ 67,125$ & $\$ 41,617$ & $\$ 9,576$ \\
Unemployment Rate & $5.5 \%$ & $14.4 \%$ & $8.4 \%$ & $2.6 \%$
\end{tabular}




\section{Hierarchical Generalized Linear Model (HGLM) Results}

A random effects (RE) Hierarchical Generalized Linear Model (HGLM) was

performed to explore the effects of two levels of the independent variable (individual and institutional factors) on default outcomes across a sample of federal student loan recipients. The analysis was performed using HLM 7.01 for Windows software (Raudenbush, Bryk, \& Congdon, 2013). An SPSS file for level-one (individual) data and level-two (institutional) data was uploaded and converted to a Multivariate Data Matrix (MDM) file. The model was specified to indicate the dichotomous outcome variable by selecting a binomial outcome (which alerts HGLM to employ a logit link function) and a Bernoulli distribution (a special case of the binomial distribution) (Raudenbush \& Bryk, 2002). Additionally, the Laplace approximation was selected to signal the software to incorporate the Laplace algorithm for model estimation, as recommended by Snijders and Bosker (2012) as efficient for estimating a model with a dichotomous outcome variable. Three models were specified: 1) an unconditional model, 2) a preliminary model to check for residuals, and 3) a final model used as the basis for the study findings.

\section{Unconditional Model}

As a first step, an unconditional model (one-way random effect ANOVA) containing no independent variables was performed to measure between-institution variability in student loan default rates among institutions in the sample (Raudenbush \& Bryk, 2002; Robson \& Pevalin, 2016). The unconditional model presents the probability of default among the institutions, absent of any additional explanatory variables (Raudenbush \& Bryk, 2002; Snijders \& Bosker, 2012).

The regression equation for the level-one null/unconditional model is: 
$\eta_{i j}=\beta_{0 j}$

The regression equation for the level-two null/unconditional model is:

$\beta_{0 j}=\gamma_{00}+u_{0 j}$

where $\mathrm{u}_{0 j} \sim \mathrm{N}\left(0, \tau_{00}\right)$

The $\gamma_{0 o}$ term represents the average logged odds of loan default across the postsecondary institutions in the sample and the $\tau_{00}$ term is the variance between institutions (Raudenbush \& Bryk, 2002). Table 14 reports the results of the Unconditional Model.

Table 14

HGLM Results: Unconditional Model

\begin{tabular}{|c|c|c|c|c|}
\hline \multirow[t]{2}{*}{ Fixed Effect } & \multicolumn{2}{|c|}{ Average Log Odds } & \multirow[t]{2}{*}{$\tau_{00}$} & \multirow[t]{2}{*}{ p-value } \\
\hline & $\gamma_{00}$ & se & & \\
\hline INTRCPT & -1.0317 & 0.0403 & 0.0213 & $<0.001$ \\
\hline Random Effect & SD & Variance & df & Chi Square p-value \\
\hline INTRCPT1, $u_{0}$ & 0.1462 & 0.0213 & 15 & 122.1853 \\
\hline
\end{tabular}

The output indicates that $\gamma_{00}=-1.0317(\mathrm{SE}=0.0403)$. By converting $\gamma_{00}$ to a probability ${ }^{9}$, we observe that for the "typical" institution with a random effect $u_{0 j}=0$, the expected rate of default is $26.3 \%$ ( 0.2 percentage points from the actual default rate for the sample) (Raudenbush \& Bryk, 2002). When conducting a standard Hierarchical Linear Model (i.e., estimation of the relationship among independent variables and a continuous dependent variable), an Interclass Correlation Coefficient (ICC) is calculated to measure the ratio of the higher-level variance to lower-level variance (Osborne, 2016;

\footnotetext{
${ }^{9}$ Probability Equation from Raudenbush \& Bryk (2002) pg. 297: Exp(-1.0317) = .3564; probability $1 /(1+\exp (-1.0317)=0.7372 ;$ probability $=26.27$.
} 
Robson \& Pevalin, 2016; Raudenbush \& Bryk, 2002). However, due to the heteroscedasticity of the level-one variance in a dichotomous outcome design, the ICC is "less informative" for HGLM, relative to the standard HLM procedure (Raudenbush \& Bryk, 2002). As recommended by Snijders and Bosker (2012), $\tau_{00}$ was used to calculate an Interclass Correlation Coefficient modified for designs with a binary outcome variable. The modified formula ${ }^{10}$ equates to 0.01 , suggesting that only $1 \%$ of the variance is attributable to between-institution variability (Raudenbush \& Bryk, 2002; Snijders \& Bosker, 2012). However, given the multilevel structure of the data, the utilization of a multilevel model remains warranted despite the small modified ICC (Gelman \& Hill, 2007; Robson \& Pevalin, 2016).

\section{Conditional Models}

After examining the null model, explanatory variables were added to the model to explore the effects of individual-level and institution-level factors on the logged odds of student loan default. A key design choice in conducting an HGLM analysis is whether to treat level-two terms as fixed or random; and, an advantage to treating level-two terms as random is the capacity to distinguish between-school and within-school variance (Clark, Crawford, Steele, \& Vignoles, 2015). Therefore, this study employed a random effect intercepts-and-slopes as outcomes model (Raudenbush \& Bryk, 2002). As a first step, per the recommendations in the HLM 7.01 for Windows software user manual (Raudenbush, Bryk, Cheong, Congdon, \& du Toit, 2011) after running a set of initial models, a residual file was exported from HLM7 to SPSS for inspection. Cases with a residual larger than 10 were removed (Osborne, 2016).

\footnotetext{
${ }^{10}$ Modified ICC Equation from Snijders \& Bosker (2012): $p=\tau_{00 /(} \tau_{00+} \pi^{2} / 3$ )
} 
In the final round of analysis, to observe changes in estimated coefficients and odds ratios regarding distinct variable groups, the conditional model was built in five stages, beginning with (1) institution-level factors only, followed by the addition of (2) demographic factors, (3) college readiness and college academic factors, (4) financial aid factors, and (5) transfer/completion factors. The continuous variables at both the levels were grand mean centered (i.e., rescaled with a mean of zero), which is appropriate when exploring the effects at multiple levels (Robson \& Pevalin, 2016). To examine model fit, - $\log 2$ likelihood (-2LL) was inspected and recorded at each model step. The -2LL value for the final model was smaller than the unconditional model, indicating an improved model fit as a result of the addition of explanatory variables (Osborne, 2016). Following is a summary of the results of the final model, which contained all level-one and leveltwo variables. A table summarizing details for each of the six models is located in the Appendix.

\section{Individual-Level Explanatory Variable Findings}

The first research question focused on the relationship between individual-level factors and default, specifically: To what extent are individual-level factors related to federal student loan default among borrowers within statewide system of public two-year postsecondary institutions?

Table 15 presents estimates of the level-one coefficients, standard errors, and odds ratios for the final model step of the model. Among the five individual-level factor groupings (demographic, college readiness, college academics, financial aid, and transfer and completion), at least one variable from each group was significantly related to student loan default outcomes. 
Table 15

HGLM Results: Estimates of Level-One Coefficients and Odds Ratios, Final Model ${ }^{11}$

\begin{tabular}{|c|c|c|c|c|}
\hline & Coefficient & SE & $\begin{array}{l}\text { Odds } \\
\text { Ratio } \\
\end{array}$ & CI \\
\hline Intercept & $-3.1612 * * *$ & 0.1092 & 0.0423 & $0.031,0.057$ \\
\hline \multicolumn{5}{|l|}{ Demographic Factors } \\
\hline Age (z-score) & $0.0405^{*}$ & 0.0196 & 1.0414 & $1.002,1.082$ \\
\hline Gender $=$ Male & $0.5757 * * *$ & 0.0336 & 1.7780 & $1.665,1.900$ \\
\hline Race/Ethnicity = Black & $-0.1577 * * *$ & 0.0452 & 0.8540 & $0.782,0.933$ \\
\hline Race/Ethnicity = Hispanic/Latino & -0.1594 & 0.1113 & 0.8525 & $0.685,1.060$ \\
\hline Race/Ethnicity = Asian & $-0.8166^{*}$ & 0.3266 & 0.4419 & $0.233,0.838$ \\
\hline Race/Ethnicity = Other & -0.1355 & 0.0898 & 0.8732 & $0.732,1.041$ \\
\hline \multicolumn{5}{|l|}{ College Readiness Factors } \\
\hline Earned GED & $0.1789 * * *$ & 0.0415 & 1.1959 & $1.103,1.297$ \\
\hline Required Developmental Reading & $0.2121 * * *$ & 0.0353 & 1.2363 & $1.154,1.325$ \\
\hline \multicolumn{5}{|l|}{ Required Developmental Math } \\
\hline Low Need & $0.2278 * * *$ & 0.0531 & 1.2558 & $1.132,1.394$ \\
\hline Medium Need & $0.3468 * * *$ & 0.0452 & 1.4146 & $1.295,1.546$ \\
\hline High Need & $0.3654 * * *$ & 0.0553 & 1.4411 & $1.293,1.606$ \\
\hline \multicolumn{5}{|l|}{ College Academic Factors } \\
\hline Number of Credits Passed (z-score) & $-0.0872 *$ & 0.0342 & 0.9164 & $0.857,0.980$ \\
\hline Cumulative GPA (z-score) & $-0.4593 * * *$ & 0.0233 & 0.6316 & $0.603,0.661$ \\
\hline \multicolumn{5}{|l|}{ Financial Aid Factors } \\
\hline Pell-Eligible & $1.2896 * * *$ & 0.0654 & 3.3631 & $3.194,4.129$ \\
\hline Total KCTCS Loan Debt (z-score) & $-0.2484 * * *$ & 0.0238 & 0.7800 & $0.744,0.817$ \\
\hline Independent & $0.5139 * * *$ & 0.0486 & 1.6718 & $1.520,1.839$ \\
\hline \multicolumn{5}{|l|}{ Transfer and Completion Factors } \\
\hline Earned Associate in Applied Science & $-1.3892 * * *$ & 0.1163 & 0.2492 & $0.198,0.313$ \\
\hline Earned Associate in Arts/Science & $-1.4028 * * *$ & 0.1633 & 0.2459 & $0.179,0.339$ \\
\hline Earned Certificate or Diploma & -0.0538 & 0.0549 & 0.9475 & $0.851,1.055$ \\
\hline Transferred to 4-Year & $-0.5589 * * *$ & 0.0773 & 0.5717 & $0.491,0.665$ \\
\hline
\end{tabular}

\footnotetext{
${ }^{11}$ As noted in Chapter 3, the Terms Enrolled variable was excluded from the HGLM analysis due to its high degree of correlation with Credits Accumulated.
} 
Demographic Factors. Research Question 1a: To what extent are demographic factors related to federal student loan default among borrowers within a statewide system of public two-year postsecondary institutions?

Among the demographic factors included in the HGLM, gender was the most strongly associated with the likelihood that a borrower will default on federal student loans. Holding all other variables in the model constant, the odds of default for a male borrower are 1.77 times greater than the odds for a female $(\mathrm{p}<.001)$, which translates to a 3\% higher predicted probability of default for male loan recipients.

Though the descriptive data indicated that borrowers who identify as Black/African American defaulted at a higher rate (Table 15), the final HGLM indicated that borrowers who identify as Black/African American are slightly less likely to default as compared to White peers, after controlling for other individual-level factors. As noted previously, independent variables were entered in the HGLM equation in a series of six stages. Model 3 contained only institution-level factors and individual-level demographic factors (age, race/ethnicity, and gender) and demonstrated a higher risk of student loan default among borrowers who identify as Black/African American $(\mathrm{OR}=$ 1.43; $\mathrm{p}<.001)$. However, by the sixth and final model, which included additional controls related to college readiness, college academics, financial aid, and completion and transfer outcomes, Black/African American borrowers possessed slightly lower default odds ratio as compared to White borrowers $(\mathrm{OR}=0.85 ; \mathrm{p}<.001)$, suggesting that differences in default rates among White and minority borrowers are attributable to other important factors in the context of the current sample. Asian borrowers were also less likely to default as compared to White peers $(\mathrm{OR}=0.44, \mathrm{p}<.05)$, which translates to a 
$2 \%$ decrease associated with probability of default for Asian borrowers, all other factors being equal. In the final model, identifying as Hispanic/Latino/a or an "other" race/ethnicity group was not significantly associated with student loan default.

Age had a statistically significant but small impact on student loan default risk: a one standard deviation increase in a borrower's age at the time a student loan enters repayment is associated with a small increase in the odds of defaulting on the loans (OR $=1.04, \mathrm{p}<.05)$.

College Readiness Factors. Research Question 1b: To what extent are college readiness factors related to federal student loan default among borrowers within a statewide system of public two-year postsecondary institutions?

All factors that measure pre-college academic readiness had a statistically significant impact on student loan default. The default odds for an individual borrower who earned a GED were 1.19 times higher as compared to the default odds for a borrower who earned a high school diploma $(\mathrm{OR}=1.19 ; \mathrm{p}<.001)$ which translates to a $1 \%$ higher predicted default probability for GED recipients. The odds of default among borrowers who required a remedial reading course were 1.23 that of borrowers who did not require a reading course $(\mathrm{OR}=1.23, \mathrm{p}<.001)$. As a borrower's need for developmental math increased, so did default risk: the odds of default among borrowers who required the highest level of developmental math need (three-levels below a collegelevel course) was 1.44 that of borrowers who did not require a remedial math course (OR $=1.44 ;$ p. $<.001)$. Notably, the coefficients and odds ratios reported control for other variables in the regression model and are therefore cumulative; thus, a loan recipient who earned a GED, requires reading, and requires the highest level of developmental math has 
a predicted probability of default that is four percent higher than a college-ready high school graduate. Despite the small effect sizes, this data collectively indicates that college readiness is related to the likelihood that a borrower will default.

College Academic Factors. Research Question 1c: To what extent are college academic factors related to federal student loan default among borrowers within a statewide system of public two-year institutions?

Both factors that measure the relationship between academic success in college and student loan default were statistically significant. Among the college academic factors, college GPA had the stronger impact on default likelihood: by calculating the inverse of the odds ratio (1/OR), we observe odds of default increased by 1.58 for every standard deviation increase in GPA. In other words, a borrower with a GPA one standard deviations below the mean $(0.83)$ has a predicted probability of default $3 \%$ higher than a borrower with a GPA equal to one standard deviation above the mean (3.25). The relationship between credits accumulated and default is also significant: for every standard deviation increase in the number of credits the borrower accumulates the likelihood of default decreases $(\mathrm{OR}=0.91, \mathrm{p} .<.05)$.

Financial Aid Factors. Research Question 1d: To what extent are financial aid factors related to federal student loan default among borrowers within a statewide system of public two-year postsecondary institutions?

The strongest predictor of student loan default was eligibility status for the income-based Pell grant: the predicted probability of default was $9 \%$ higher for loan recipients eligible for the Pell grant as compared to borrowers not Pell-eligible (according to the most recent FAFSA on file, prior to the year the cohort entered repayment) (OR = 
$3.63, \mathrm{p}<.001)$. Borrowers classified as financially independent had default odds 1.6 times higher than borrowers classified as financially dependent.

The final HGLM indicates that a larger sum of student loan debt does not increase the likelihood that a borrower will default. Holding all other factors constant, as a borrower's total sum of student loan debt increased, risk of default decreased ( $\mathrm{OR}=0.78$, $\mathrm{p}<.001)$. Taken the inverse, a borrower with a total student loan debt sum one standard deviation below the mean has 2.56 higher odds of default as compared to a borrower with a total sum of student loan debt one standard deviation below the mean.

Transfer and Completion Factors. Research Question 1e: To what extent are completion and transfer factors related to federal student loan default among borrowers within a statewide system of public two-year postsecondary institutions?

The completion of an Associate's degree or transfer to a four-year institution were related to a decreased risk of default. The odds ratio for borrowers who earned an Associate degree in Applied Science or General Education was 0.24 and 0.24, respectively. The inverse of the odds ratio demonstrates that borrowers who exit college prior to completing an Associate degree are roughly four times as likely to default as compared to borrowers who earn an Associate degree. Borrowers who did not transfer to a four-year institution were roughly 1.75 times as likely to default as compared to borrowers who did transfer to a four-year college or university. Notably, the finding did not hold true for other types of credentials; the relationship between earning a certificate and/or diploma and default was not significant.

Summary of Individual-Level Findings. Overall, most of the individual-level factors were significantly associated with student loan default, but effect sizes were 
generally small. Collectively, these findings reveal that there are many risk factors associated with default. The factors most strongly associated with an increased risk of default include being eligible for the income-based Pell grant, being male, being classified as financially independent, requiring a medium or high level of developmental math, and requiring a developmental reading course. Factors most strongly associated with a decreased likelihood of student loan default include earning an Associate degree, earning a higher cumulative GPA while enrolled in college, and transferring to a fouryear institution prior to entering repayment.

\section{Institution-Level Explanatory Variable Findings}

The second research question focused on the relationship between institutionlevel variables and default, specifically: To what extent are institution-level factors related to federal student loan default among borrowers within a statewide system of public two-year postsecondary institutions?

Table 16 presents estimates of institution-level coefficients, standard errors, and odds ratios in the final model step of the model. The institution-level factors in the study include factors related to size, composition and locale factors, institutional performance factors, institutional spending factors, and macroeconomic factors. Among the institutional-level factors, only two variables were significantly related to student loan default: the percent of students at the institution eligible for the income-based Pell grant and the unemployment rate for the county in which the institution is situated. 
Table 16

HGLM Results: Estimates of Level-Two Coefficients and Odds Ratios, Final Model ${ }^{12}$

\begin{tabular}{|c|c|c|c|c|}
\hline & Coefficient & SE & $\begin{array}{l}\text { Odds } \\
\text { Ratio } \\
\end{array}$ & CI \\
\hline Intercept & $-3.1612 * * *$ & 0.1092 & 0.0423 & $0.031,0.057$ \\
\hline \multicolumn{5}{|l|}{ Size, Composition, and Locale } \\
\hline Total FTE (z-score) & -0.000 & 0.0000 & 0.9999 & $1.000,1.000$ \\
\hline Percent Eligible for Pell & $-0.0217 *$ & 0.0063 & 0.9785 & $0.962,0.996$ \\
\hline Town Locale & 0.0939 & 0.0929 & 1.0985 & $0.849,1.422$ \\
\hline Rural Locale & 0.1542 & 0.1055 & 1.1667 & $0.870,1.564$ \\
\hline Appalachian Locale & 0.1763 & 0.1035 & 1.1928 & $0.895,1.590$ \\
\hline \multicolumn{5}{|l|}{ Institutional Performance } \\
\hline Retention Rate & 0.0093 & 0.0047 & 1.0094 & $0.996,1.023$ \\
\hline Graduation Rate & 0.0031 & 0.0038 & 1.0031 & $0.992,1.014$ \\
\hline \multicolumn{5}{|l|}{ Institutional Spending } \\
\hline Instructional Dollars per FTE (z-score) & -0.0000 & 0.0000 & 0.9999 & $1.000,1.000$ \\
\hline Academic Dollars per FTE (z-score) & 0.0001 & 0.0001 & 1.0001 & $1.000,1.001$ \\
\hline \multicolumn{5}{|l|}{ Macroeconomic } \\
\hline County Unemployment Rate & $0.0434 *$ & 0.0173 & 1.0444 & $0.995,1.096$ \\
\hline
\end{tabular}

Size, Composition, and Locale Factors. Research Question 2a: To what extent is campus size, composition, and locale related to federal student loan default among borrowers within a statewide system of public two-year postsecondary institutions?

Measures for institutional size (as indicated by Full Time Equivalent enrollment) and locale (Rural, Town, or Suburb; Appalachian County indicator) were not statistically significant in the final sample, after controlling for individual-level factors. As indicated

12 As noted in Chapter 3, Median Annual Income and Percent Awarded Loans were excluded from the HGLM analysis due to its high degree of correlation other variables. 
in the Stepwise Model (Appendix), prior to controlling for borrower-level characteristics, institutional size and the percent of borrowers who obtain loans were statistically significant. This finding suggests that all else being equal, campus size and location do not play a significant role in the default outcomes of borrowers.

Institutional Performance Factors. Research Question 2b: To what extent are institutional performance factors related to federal student loan default among borrowers within a statewide system of public two-year postsecondary institutions?

The two measures of institutional performance - IPEDS Official Graduation Rate and IPEDS Official Retention Rate - were not significantly associated with student loan default, in the first nor final model, and did not appear to influence an institution's propensity for student loan default.

Institutional Spending Factors. Research Question 2c. To what extent are institutional spending factors related to federal student loan default among borrowers within a statewide system of public two-year postsecondary institutions?

Measures related to an institution's spending in terms of Academic Support and Instruction Support (per Full Time Equivalent enrollment) were not statistically significant in the final sample, after controlling for borrower-level factors. However, as indicated in the Stepwise Model in the Appendix, both factors were statistically significant prior to controlling for financial aid outcomes. This finding suggests that all else being equal, institutional spending is not significantly related to a borrower's risk of student loan default. 
Macroeconomic Factors. Research Question 2d. To what extent are

macroeconomic factors related to federal student loan default among borrowers within a statewide system of public two-year postsecondary institutions?

In the final model, holding all else constant, a one-percentage point increase in the unemployment rate for the county in which the institution is situated is associated with a 1.04 increase in default odds.

Summary of Institution-Level Findings. Overall, the institution-level factors did not have a strong effect on predicting student loan default among borrowers. No factors that measured institutional performance and institutional spending were significantly associated with student loan default, nor were an institution's FTE enrollment or locale/region. The Unemployment Rate for the county in which the institution is situated had a significant yet small effect on default likelihood (as unemployment rate increased; so did default odds). And, the percent of students eligible for the Pell grant also had a significant yet small effect.

\section{Findings: Research Question 3}

The final research question focused on the relationship between individual and institution level variables, specifically: What is the relative impact of individual-level and institution-level factors and federal student loan default among borrowers within a statewide system of two-year public postsecondary institutions?

The modified ICC as calculated from the Unconditional Model output (Table 14) suggested that only $1 \%$ of the variance in student loan default outcomes is attributable to between-institution variability (Raudenbush \& Bryk, 2002; Snijders \& Bosker, 2012). Thus, this analysis suggests that individual-level factors possessed much more 
explanatory power in determining student loan default likelihood, relative to institutionlevel factors. This finding was mirrored within the conditional model levels at each level: while most of the individual-level factors were significantly associated with student loan default, only 2 of the institution-level factors were associated with student loan default.

\section{Summary}

Chapter 4 articulated the findings from the HGLM analysis respective to student loan default outcomes among federal student loan recipients who attended an institution within a two-year public system of community and technical colleges. The following chapter will contextualize these findings in the existing body of research and discuss recommendations for policy and practice. 


\section{CHAPTER V \\ DISCUSSION}

This chapter presents a summary of findings related to individual-level and institution-level factors associated with student loan default among borrowers in one statewide system of two-year public postsecondary institutions. The key findings for the study are stated and situated in the extant student loan default research. Human Capital Theory is employed to interpret the significance of study findings to the American federal financial aid system. The chapter concludes with a discussion of recommendations for federal student aid policy and financial aid administration practice, derived from study

findings. A conclusion reiterates the significance of study findings to higher education in the United States.

\section{Key Findings}

\section{Key Findings: Research Question One}

Research Question One: To what extent are individual-level factors related to federal student loan default among borrowers within a statewide system of public twoyear postsecondary institutions?

The first research question addressed the relationship between individual-level factors and federal student loan default. The HGLM analysis indicated that at least one variable in each of the independent variable groups (demographic, college readiness, college academics, financial aid, and transfer/completion) was significantly related to 
student loan default. However, being eligible for the income-based Pell grant, being male, being classified as financially independent, requiring a medium or high level of developmental math, and requiring a developmental reading course emerged as the strongest predictors of student loan default, while earning an Associate degree, earning a higher cumulative GPA while enrolled in college, and transferring to a four-year institution prior to entering repayment were the strongest predictors of successful repayment.

Collectively, the study findings are consistent with prior research that demonstrates a robust association between academic success and student loan repayment. The present study indicated that all else being equal, borrowers who earn an Associate degree are roughly four times less likely to default as compared to non-completers - a finding consistent with numerous studies that find earning a degree is one of the strongest predictors of successful repayment (Barone, 2006; Barone, Steiner, \& Teszler, 2006; Dynarski, 1994; Greene, 1989; Herr \& Burt, 2005; Hillman, 2014a; Knapp \& Seaks, 1992; McKinney, Gross, \& Inge, 2014; Steiner \& Barone, 2014; Volkwein \& Szelest, 1995). Notably, while earning a sub-Associate credential (certificate or diploma) was associated with a decreased risk of default, the effect was not as strong as earning an Associate degree - another finding congruent with prior student loan default research (McKinney, Gross, \& Inge, 2014; Hillman \& Campbell, 2015) and research that suggests that while credential earners generally experience a small and positive return on investment with certificates and diplomas (Klor de Alva \& Schneider, 2013), monetary returns to Associate degrees are generally higher (Belfield \& Bailey, 2017). 
Notably, however, this study suggests that Associate degree completion may not be a panacea for eliminating student loan default at two-year public institutions. Among Associate degree completers in the study sample, $7.7 \%$ defaulted on loans during the three-year default monitoring window, which is roughly the national rate of default among all borrowers (regardless of degree completion status) who attend four-year public institutions (U.S. Department of Education, 2016a). A 2015 descriptive analysis of borrowing and default among student loan recipients attending public community colleges in Iowa found a comparable default rate (8.5\%) among Associate degree graduates (Campbell and Hillman, 2015, p. 24). This suggests that although degree earners are much less likely to default than non-completers, more research should explore the extent to which graduates possess the skills and credentials needed to find gainful employment after exiting college.

Among many community college students, academic success is tied to college readiness, as evidenced by numerous studies that demonstrate students who require developmental education are at greater risk of non-completion (American Association of Community Colleges, 2016; Community College Research Center, 2014; McKinney, Novak, \& Hagedorn, 2016). By incorporating and quantifying the relationship between college readiness and student loan default, this study extends the extant body of research that primarily focuses on academic outcomes in college. All else being equal, borrowers who required developmental reading or a high level of developmental math were significantly more likely to default than borrowers who were college-ready in the subjects $(\mathrm{OR}=1.23$ and 1.44 , respectively). As discussed in greater detail later in this chapter, this finding has significant implications for practice, as it emphasizes the capacity for 
institutions to develop interventions targeted at borrowers most likely to default even before a student begins coursework. Further, this finding contributes to a current discussion about the use of student loans to pay for developmental education classes (McKinney, Novak, \& Hagedorn, 2016), as discussed in the following section of this chapter.

In addition to academic success, two factors related to federal financial aid were significantly related to borrowers' likelihood of default on student loans. Being eligible for the Pell Grant had a significant and sizeable effect on increasing a borrower's probability of default $(\mathrm{OR}=3.63, \mathrm{p}<.001)$. The income-based Pell Grant serves as a proxy for income, thus emphasizing the relationship between socioeconomic status and student loan default even when controlling for academic outcomes, as also demonstrated in many prior studies (Gross, Cekic, Hossler, \& Hillman, 2009; Herr \& Burt, 2005; Hillman, 2014; McKinney, Gross, \& Inge, 2014; Knapp \& Seaks, 1992; Steiner \& Teszler, 2005; Woo, 2002). Additionally, being financially independent was also associated with a significantly higher risk of student loan default; all else being equal, borrowers classified as financially independent had default odds 1.6 times higher than financially dependent borrowers. Considering that community colleges enroll a large proportion of adults and independent college students (Ma \& Baum, 2016), this may be an important contributor to higher rates of default at two-year public institutions.

This study contributes to a growing body of research that documents that borrowers with the smallest student loan debt sums are actually at greatest risk of default (Chakrabarti, Haughwout, Lee, Scally, \& van der Klaauw, 2017; McKinney, Gross, \& Inge, 2014). The average debt among defaulters in the sample was $\$ 8,418$ (Table 8) and 
$42 \%$ of borrowers in default owed $\$ 5,000$ or less. This finding provides additional evidence of the relationship between academic success as demonstrated by credit accumulation and continued enrollment; as borrowers remain enrolled in college, they are more likely to accumulate a greater burden of student loan debt, but are also more likely to have accrued a larger number of credits and/or credential(s).

This study indicated that factors related to college readiness, academic success in college, financial aid, and college completion and transfer, are significantly related to student loan default; however, some demographic characteristics continue to play a role in determining risk of student loan default even after controlling for these factors. Interestingly, this study revealed that being male was associated with a higher probability of student loan default. While the extant research presents mixed findings regarding the impact of gender on default, other studies also found higher rates among male borrowers (Barone, Steiner \& Teszler, 2005; Flint, 1994; Flint 1997; Podgursky, Ehlert, Monroe \& Watson, 2002; Steiner \& Barone 2014; Woo, 2002). Understanding the contributors driving gender disparity in student loan default rates warrants additional research.

This study deviated from much of the existing literature with regard to the relationship between race/ethnicity and student loan default. One notable inconsistency in the current study findings and much of the existing body of research is that the relationship between loan default and race/ethnicity disappeared after controlling for other individual-level variables such as college readiness, college academics, and completion/transfer outcomes. Many previous studies (primarily those conducted with four-year student populations or with a multi-sector sample of borrowers) find that even after controlling for academics, default rates remain disparate by race/ethnicity, 
particularly among borrowers who identify as White versus borrowers who identify as Black/African American or Hispanic/Latino/a (Gross, Cekic, Hossler, \& Hillman, 2009; Herr \& Burt, 2005; Hillman, 2014a; Lochner \& Monge-Naranjo, 2014). Notably, two previous studies that focus exclusively on community college student populations also found that race/ethnicity also did not emerge as a significant variable after accounting for

other controls (McKinney, Gross, \& Inge, 2014; Steiner \& Barone, 2014), suggesting that this may be an important distinction among two- and four-year student populations.

\section{Key Findings: Research Question 2}

Research Question 2: To what extent are institution-level factors related to federal student loan default among borrowers within a statewide system of public twoyear postsecondary institutions?

The second research question addressed the relationship between institution-level factors and federal student loan default. Among the eleven institution-level factors included in the HGLM analysis, only two factors were significantly associated with student loan default in the final regression model. The two variables that emerged as significant were related to enrollment composition (percent of students at the institution who were eligible for the Pell Grant) and macroeconomic context (unemployment rate for county in which the postsecondary institution is situated). In both cases, however, effect sizes were extremely small and inconsequential from a practical perspective.

Perhaps the most imperative discovery is the absence of a significant or sizeable effect among any of the institution-level variables with regard to student loan default. This finding is particularly important considering the inclusion of variables related to institutional performance (graduation rates and retention rates) and dollars spent on 
instruction and academic support per FTE student. The juxtaposition of this result with other studies that explore the relationship between institution-level factors and student loan default presents an important contribution to the existing debate over the relative influence of individual-level and institution-level factors. A number of prior studies document a significant relationship between institutional cohort default rates and firstyear retention and graduation rates (Belfied, 2013; Goodell, 2016; Webber \& Rogers, 2014) or spending on instruction and/or student services (Webber \& Rogers, 2014). Notably, these findings are derived from studies that measure default at the institutionlevel (i.e., the dependent variable is cohort default rate, not borrower-level default status), which by way of aggregation ignores variability among the individuals in the sample which can obscure results (Raudenbush \& Bryk, 2002; Robson \& Pevalin, 2016; Woltman, Feldstain, MacKey, \& Rocchi, 2012). The present study demonstrates the utility of HLGM in exploring student loan default, and suggests that the inclusion of borrower-level data explains institution-level differences.

\section{Key Findings: Research Question 3}

Research Question 3: What is the relative impact of individual-level and institution-level factors and federal student loan default among borrowers within a statewide system of two-year public postsecondary institutions?

The third research question posed in this study pertained to distinguishing the relative influence of the individual-level and institution-level factors. The modified formula used to calculate an Interclass Correlation Coefficient (ICC) for the unconditional HGLM indicated that only $1 \%$ of the variance in cohort default rates was attributable to the institution-level factors $(p=.01)$, suggesting that individual-level 
variables possess much more explanatory power, relative to institution-level variables, in predicting student loan default. This study focuses exclusively on main effects; however, future research may extend understanding of the relationship between individual-level and institution-level factors by exploring cross-level interaction effects.

\section{Theoretical Insight from Human Capital Theory}

As discussed in Chapter 2, Human Capital Theory is a principle underlying the American federal student loan program: the U.S. government provides educational loans so that all individuals are able to access higher education regardless of socioeconomic status, on the premise that investment in human capital benefits both individuals and society (Becker, 2008; Dynarksi, 2015, Paulsen, 2001; Scott-Clayton, 2017). This point is supported by ample research that documents a significant return on investment for postsecondary credentials (Carnevale, Cheah, \& Hanson, 2015; Carnevale, Rose, \& Cheah, 2011). Importantly, however, underlying the application of Human Capital Theory to rationalize the provision of student loans is that loan beneficiaries will ultimately accumulate verification of human capital in the form of certificates, diplomas, and degrees.

Unfortunately, the descriptive data revealed that this assumption falls tremendously short among the community college student population analyzed in this study. Less than one fifth of borrowers included in the sample earned an Associate degree prior to entering repayment on federal student loans (Table 9). And, there is ample evidence that these outcomes are congruent with nationwide trends in community college completion: nationally, average completion rates among community colleges equates to roughly 20\% (National Center for Education Statistics, 2016). Employing 
Human Capital Theory as a lens to analyze data pertaining to student loan repayment and default raises questions about the degree to which federal financial aid programs are effectively managing to facilitate an environment in which the benefits of continued attendance outweigh the costs among community college attendees. Further, the Human Capital Theory lens demonstrates that for the American federal financial aid system to meet the assumptions and goals underlying its student loan program, policymakers must focus on strategies to increase educational attainment in tandem with access to financial aid.

\section{Considerations for Policy and Practice}

The results obtained in this study inform national student financial aid policy and institutional practice pertaining to student loan default management. The following section presents recommendations for policy and practice, drawn from study findings.

\section{Recommendations for Policy}

This study presents three primary recommendations relevant to federal financial aid policy: 1) reconsider student loan default metrics, 2) evaluate the use of student loans for developmental education, and 3) employ financial aid reform to curb student loan default.

\section{Reconsider Student Loan Default Metrics}

As noted in earlier chapters, cohort default rates above certain thresholds carry potentially severe penalties, including ineligibility to participate in the federal student aid program; thus, cohort default rates (CDR) presently function as an accountability metric for postsecondary institutions. This study contributes to a growing body of research that suggests default rates are a function of the characteristics of students enrolled at a 
postsecondary institution. This finding raises questions about the utilization of CDRs as an accountability metric: under the current scheme, institutions that serve a higher proportion of at-risk students are much more likely to report higher cohort default rates (Gillen, 2013; McCormick, 1987; TICAS, 2013), therefore putting exceptional burden on institutions that serve high-risk student populations that the loan program is designed to serve. $^{13}$

Webber (2017a, 2017b) recently called attention to the fact that the binary nature of the CDR $30 \%$ threshold places a disproportionate burden on institutions who serve a higher proportion of at-risk borrowers, relative to more selective colleges and universities - there is little incentive to reduce cohort default rates among colleges and universities who fall under the $30 \%$ threshold. There is some recourse for institutions to appeal penalties for reasons related to students' economic disadvantage and/or loan program participation rate (TICAS, 2016; Department of Education, 2016); however, considering the well-documented income-based stratification among institutions by type and sector raises questions about the static CDR threshold as opposed to one that considers institutional context embedded into the system of accountability.

A few scholars propose recommendations for improving the current system for measuring student loan default among postsecondary institutions. For example, Gillen (2013) proposed calculating predicted default rates - based on characteristics of students enrolled at a given institution, such as Ability to Pay - and juxtaposing with an actual institutional default rate to assess whether a college or university's default rate is within a

\footnotetext{
${ }^{13}$ Notably, it appears that despite the published sanctions, the Department of Education is taking a lenient stance and is working with community colleges and HBCUs to reduce default, sparing some institutions who would have technically lost eligibility from losing eligibility (U.S. Department of Education, 2014).
} 
suitable range (Gillen, 2013). Webber (2017a, 2017b) advocates for risk-sharing as a mechanism to more disproportionately reward and penalize institutions in which a significant proportion of borrowers default. Under a risk-sharing scheme, institutions would be required to pay a proportion of the defaulted loans back to the federal government (i.e., "skin in the game" proposals) (Webber, 2017a, 2017b; Alexander, 2015). As a component of some of the proposed reform, some suggest awarding dollars generated as a result of the risk-sharing policy to institutions based on the number or proportion of Pell Grant or low-income enrollments or graduates, thus promoting reallocation of dollars to institutions that effectively serve at-risk student populations (Webber, 2017a, 2017b).

Another concern pertaining to CDRs is the inability of the metric to demonstrate a complete evaluation of student loan utilization, repayment, and default at a given institution. Because the rate is merely a percentage of borrowers who default, the rate does not take into consideration the proportion of borrowers from a given institution who do and do not borrow (Hillman, 2014b, TICAS, 2013). Thus, The Institute for College Access and Success (TICAS) proposed a Student Default Risk Index (SDRI) that incorporates a measure of the proportion of students who borrow, thereby indicating a more accurate reflection of default risk for students attending a given institution (TICAS, 2013; TICAS, 2016). Further, because the default rates are measured for a three-year cohort, the number of borrowers who default or struggle with repayment may be severely underestimated (because some borrowers default after the three-year window) (Cunningham \& Kienzl, 2011; Field, 2010; Hillman, 2014b; Kesterman, 2006). Additional concerns are raised pertaining to the capacity for institutions to manipulate 
CDRs by directing students to file for deferment or forbearance in order to manipulate the default rate denominator (Hillman, 2014b) or restricting access to loans for low-income and/or high risk students enrolled (Gross \& Hillman, 2014b).

Considering the issues stated above, as a component of its policy agenda the American Association of Community Colleges (AACC) advocates for a reexamination of the current system of CDR measurement and sanction rules and the establishment of metrics that better reflect actual repayment outcomes (American Association of Community Colleges, 2015). By highlighting the high rates of default among the community college student population, this study offers further evidence of the need for more consideration about how to formulate a better structure for measuring student loan default.

\section{Evaluate the Use of Student Loans for Developmental Education}

This study confirms that a high proportion of students who borrow federal student loans require one or more developmental education courses and demonstrates that borrowers who are not college ready may be much more likely to default. Among the sample of borrowers analyzed in this study, $38 \%$ of borrowers required a developmental reading course and nearly $70 \%$ required at least one developmental math course. This is reflective of national trends in community college student enrollment; nationally, the American Association of Community Colleges (AACC) reports that $67 \%$ of entering community colleges students require at least one remedial education class prior to enrolling in college-level courses (AACC, 2016).

The high rate of non-completion among borrowers who require developmental education has led some scholars to consider the efficacy of providing student loans for 
developmental education courses (King, McIntosh, \& Bell-Ellwanger, 2017; McKinney \& Burridge, 2015; McKinney, Novak, \& Hagedorn, 2016). McKinney, Hagedorn, and Novak (2016) analyzed the relationship between financial aid and student retention and persistence among academically underprepared community college students. The findings suggest that while about two thirds of the population dropped out (owing an average of $\$ 7,145$ on average), borrowing did not have a significant influence in the likelihood that a student would persist or complete (McKinney, Hagedorn, Novak, 2016). As noted by the study authors, these data raise complex policy questions about how to balance access and equitable borrowing for underprepared and at-risk students, and ensure that students are not left with unmanageable debt (McKinney, Hagedorn, \& Novak, 2016).

\section{Employ Financial Aid Reform to Curb Student Loan Default}

Among federal student loan recipients analyzed in this study, roughly one in four borrowers defaulted on student loans within three years of entering repayment. This finding, coupled with national data that demonstrates high cohort default rates among community colleges, raises questions about how American federal financial aid policy can facilitate the modification of practices and regulations to enable improved outcomes for borrowers, institutions, the federal government, and taxpayers. The National Association of Student Financial Aid Administrators (NASFAA) is a member-based student aid advocacy organization that regularly convenes policy groups that formulate and present recommendations pertaining to financial aid policy reform. A recent NASFAA Task Force on Consumer Information recommended that the Department of Education revamp student loan consumer information practices by developing timely 
information materials and discontinuing its "one-size-fits all" approach pertaining to loan disclosures and debt management (NASFAA, 2014, p. 4). This recommendation connects to a host of research that suggests complexities embedded in the financial aid program may thwart successful repayment (Akers, 2013; Bill and Melinda Gates Foundation, 2015; NASFAA, 2013). Recent research initiatives such as the Reimagining Aid Design and Delivery (RADD) project support research on student financial aid reform and the adoption of policies and practices that aim to increase financial aid access, degree attainment, and loan repayment outcomes (Bill and Melinda Gates Foundation, 2013). For example, many scholars advocate for the implementation of an automatic income-based repayment scheme (NASFAA, 2013; New America, 2014), the adoption of alternative loan disbursement plans in which students accumulate aid throughout the semester (Weissman, Cerna, Cullinan, \& Baldiga, 2017), and FAFSA simplification (Akers, 2013; Bill and Melinda Gates Foundation, 2015). The findings in this study, coupled with the extant research on student loan default, stress the great urgency for policymakers and the Department of Education to seriously consider recommendations for improving the federal financial aid program as proposed by researchers and advocacy organizations.

\section{Recommendations for Practice}

The findings from this study can also be used to inform institutional practice pertaining to student loan default management and prevention. Following are four recommendations for institutional default management practices, based on study findings.

\section{Facilitate Early and Targeted Intervention Processes}


This study presents an opportunity for community colleges to leverage data pertaining to default risk factors to formulate targeted intervention strategies among students at risk of default. The present study demonstrates that many community college students who borrow federal student loans exit college prior to earning a credential. High rates of non-completion and early withdrawal underscore the necessity for institutions to establish student financial aid education and outreach that is situated early and often throughout a student's educational pathway. As recommended by The Institute for Access and Success (2014), institutions must ensure that communication pertaining to student loan repayment and exit counseling is communicated to "all students - not just graduating students" (p. 4). Intervention and outreach strategies must be proactive on the part of the institution, as reactive policies or processes driven by a traditional graduation exit may be too late for borrowers at greatest risk of defaulting on student loans (Looney, 2011; McKinney, Gross, and Burridge, 2014). For example, McKinney, Gross, and Burridge (2014) recommend that institutions implement intentional early alert monitoring systems for high-risk borrowers; by doing so, institutions will be better equipped to provide intervention and follow-up prior to or directly after a student exits. Significantly, per federal student loan regulations most institutions have a process for identifying grant recipients and borrowers who fail to make Satisfactory Academic Progress (SAP) towards a credential (U.S. Department of Education, 2017). The characteristics of borrowers who default on student loans indicate that many defaulters will meet criteria to be probated or suspended due to failure to make satisfactory academic progress. By combining efforts to identify and process students on SAP with efforts to reduce student 
loan default, institutions can help ensure at-risk borrowers students are steered back on track - both academically and financially (Steiner \& Barone, 2014).

\section{Develop a College-Wide Default Management Plan}

The present study suggests that factors related to academic success may be among the most crucial in determining the likelihood that a borrower will default on student loans. Thus, strategies to reduce student loan default must extend beyond the financial aid office to other institutional areas (Charles, et. al., 2016; TICAS, 2016). The U.S. Department of Education advises postsecondary institutions to develop a student loan default management plan that tackles default from a holistic institutional perspective (U.S. Department of Education, 2016e). As a function of the plan, institutions are advised to convene a default management Task Force that includes representatives from academic affairs, student affairs, institutional research, and other stakeholders, in addition to financial aid staff. By facilitating open communication and dialogue regarding the prevalence and consequences of student loan default, administrators, faculty, and staff can collaborate to develop integrated default management practices. Other ways that institutions can develop processes that approach student loan default from a holistic perspective is by embedding default management practices into other areas of engagement and instruction. For example, some institutions have embedded financial literacy education into first-year student success classes and/or gateway courses (TICAS, 2016).

\section{Support Students in Finding Employment}

Despite the robust evidence regarding the relationship between degree completion and successful repayment, the descriptive statistics revealed that $7.7 \%$ of Associate 
degree earners defaulted on student loans, with rates varying considerably by academic program. This fact serves as an indicator that institutions may consider taking additional action to confirm that borrowers can find gainful employment opportunities and are connected to the local workforce and economy (Looney, 2011). When assessing student loan default outcomes, institutions should examine program-level data on degree attainment and student loan default. By monitoring gainful and job market outcomes for programs offered, and ensuring programmatic offerings are connected to workforce needs, institutions can help ensure graduates will be able to find employment, and thus more likely to possess the capacity to repay student loans (TICAS, 2016).

\section{Continue to Participate in the Student Loan Program}

The risk of potential Title IV eligibility loss has led some community colleges to opt out of the student loan program entirely (McKinney, Gross, \& Burridge, 2014; TICAS, 2016). A recent analysis conducted by The Institute for College Access and Success estimated that nearly 10 percent of community college students are enrolled in a two-year public institution that does not award federal student loans (TICAS, 2016).

Gross \& Hillman (2014) note the need for institutions to adopt a "mission-focused perspective" when considering participation in the federal student loan program. One of the key facets of the community college is the open-door access that two-year public institutions provide, and loans help to facilitate that access. When institutions dismantle access to federal student loans, students may decide to use other forms of debt - such as credit cards or private loans - to pay for tuition or other associated costs of attending college or opt to enroll in fewer credit hours (McKinney, Gross, \& Burridge, 2014). While Wiederspan (2015) found that Pell-eligible students were more likely to borrow 
when institutions offered access to federal loans, the students were also more likely to attempt a greater number of credit hours, which correlates to successful completion of a degree and repayment. High-risk borrowers are "the very students that federal assistance was designed to rescue, to aid" (McCormick, 1987, p. 33). Thus, non-participation in the federal student loan program may raise more problems than solutions.

\section{Conclusions}

Millions of U.S. college students are enrolled in community college and many rely on federal student loans to pay for tuition, books, and other expenses. However, one in five federal student loan recipients who attend a public two-year institution default on federal student loans within three years of entering repayment (Department of Education, 2016a). The mission of the American community college is to provide open access to higher education for all individuals seeking educational opportunity - regardless of socioeconomic status, previous educational experiences, or geographic locale. The rates of student loan default observed among many two-year institutions is one manifestation of the complexities associated with providing open-access to higher education.

This study identified a number of factors associated with an increased risk of student loan default among community college students, which include: being eligible for the income-based Pell grant, being male, being classified as financially independent, requiring a medium or high level of developmental math, requiring a developmental reading course, entering repayment prior to earning an Associate degree or transferring to a four-year institution, and earning a low cumulative GPA while enrolled in college. By identifying factors associated with student loan default specific to the community college student population, this study aims to provide college administrators and policymakers 
with information necessary to design interventions and implement practices that intend to reduce the prevalence of student loan default among borrowers who attend community college.

By providing additional evidence of the dearth of influence of institution-level factors on student loan default outcomes, this study emphasizes the need for a shift in policy pertaining to the use of cohort default rates in measuring and addressing student loan default. This issue is particularly relevant amid the use of broad metrics to facilitate performance-based funding schemes in many states. While evaluation and accountability is a crucial aspect of policy formulation, the student loan default issue justifies an intensified focus on policy that aims to support federal student loan recipients who possess risk factors associated with default and the institutions that serve these borrowers. This issue is central to the efficacy of the American federal student loan program, to the effectiveness of community colleges, and to the development of American workforce and economy. 


\section{REFERENCES}

Acemoglu, D. \& Autor, D. (2011). Lectures in Labor Economics. Cambridge, MA: Massachusetts Institute for Technology. Retrieved from: http://economics.mit.edu/files/4689

Akers, B. (2013). The next steps: Building a reimagined system of student aid. Brookings Institution. Washington, DC: Brookings Institution.

Akers, E.J. \& Chingos, M.M. (2014, June). Is a student loan crisis on the horizon? Washington, DC: Brookings Institution.

Addo, F.R., Houle, J.N., \& Simon, D. (2016). Young, Black, and (still) in the red: Parental wealth, race, and student loan debt. Race and Social Problems, 8(1), 6476. DOI 10.1007/s12552-016-9162-0.

Alexander, L. (2015). Risk-Sharing / Skin in the Game Concepts and Proposals. Washington, DC: Senate Committee on Health, Education, and Labor Pensions. Retrieved from: https://www.help.senate.gov/imo/media/Risk_Sharing.pdf American Association of Community Colleges. (2017). "Students at Community Colleges.” Washington, D.C.: American Association of Community Colleges. Retrieved from: http://www.aacc.nche.edu/AboutCC/Trends/Pages/studentsatcommunitycolleges.a $\operatorname{spx}$

American Association of Community Colleges. (2016). Ready - or not? Data Points, 4(8). Washington, D.C.: American Association of Community Colleges.

American Association of Community Colleges. (2015a). Community College Completion: Progress toward goal of 50\% increase. Washington, D.C.: American Association of Community Colleges.

American Association of Community Colleges (2015b). FY 2012 Cohort Default Rates Raise Issues for Community Colleges and Policymakers. Washington, D.C.: American Association of Community Colleges. Retrieved from: http://www.aacc.nche.edu/newsevents/News/articles/Pages/10082015_2.aspx 
Andruska, E.A., Hogarth, J.M., Fletcher, C.N., Forbes, G.R. \& Wohlgemuth, D.R. (2014). Do you know what you owe? Students' understanding of their student loans. Journal of Student Financial Aid, 44(2), 125-148.

Bailey, T. (2009). Challenge and opportunity: Rethinking the role and function of developmental education in community college. New Directions for Community Colleges, 145, 11-30.

Bailey, T.R. \& Averianova, I.E. (1998). Multiple missions of community colleges: Conflicting or complementary? New York, NY: Community College Research Center.

Bailey, T. \& Smith Jaggers, S. (2016). When college students start behind. New York, NY: The Century Foundation.

Becker, G.S. (1975). Human Capital: A theoretical and empirical analysis with special reference to education. New York: National Bureau of Economic Research.

Barone, S. (2006). Multivariate analysis of student loan defaulters at Prairie View A\&M University. Austin, TX: Texas Guaranteed Research and Analytical Services.

Barone, S., Steiner, M. \& Teszler, N. (2005). Multivariate analysis of student loan defaulters at Texas A\&M University - Kingsville. Austin, TX: Texas Guaranteed Research and Analytical Services.

Becker, K.A., Krodel, K.M., Tucker, B.H. (2009). Understanding and engaging underresourced college students: A fresh look at the influence of economic class on teaching and learning in higher education. Highlands, Texas: aha! Process, Inc.

Becker, G.S. (2008). Human Capital. The Concise Encyclopedia of Economics. Library of Economics and Liberty.

Retrieved from: http://www.econlib.org/library/Enc/HumanCapital.html

Belfield, C.R. (2013). Student loans and repayment rates: The role of for-profit colleges. Research in Higher Education, 54, 1-29.

Belfield, C. \& Bailey, T. (2017). The labor market returns to sub-baccalaureate college: A review. New York, NY: Center for Analysis of Postsecondary Education and Employment. Retrieved from: http://capseecenter.org/wpcontent/uploads/2017/04/labor-market-returns-sub-baccalaureate-collegereview.pdf 
Bell, B.A., Morgan, G.B., Schoeneberger, J.A., Loudermilk, B.L. Kromrey, J.D., \& Ferron, J.M. (2010). Dancing the Sample Size Limbo with Mixed Models: How Low Can You Go? SAS Global Forum 2010. Paper 197-2010.

Bill and Melinda Gates Foundation. (2013). Reimagining Aid Design and Delivery.

Seattle, WA: Bill and Melinda Gates Foundation. Retrieved from:

http://postsecondary.gatesfoundation.org/reimagining-aid-design-and-delivery/

Bill and Melinda Gates Foundation. (2015). Better for Students: Simplifying the Federal

Financial Aid Process. Seattle, WA: Bill and Melinda Gates Foundation.

Retrieved from: http://postsecondary.gatesfoundation.org/wpcontent/uploads/2015/07/FAFSA-Approach_FINAL_7_7_15.pdf

Bricker, J., Brown, M., Hannon, S. \& Pence, K. (2015, August 7). How much student debt is out there? Washington, DC: Board of Governors of the Federal Reserve. Retrieved from: https://www.federalreserve.gov/econresdata/notes/fedsnotes/2015/how-much-student-debt-is-out-there-20150807.html

Campbell, C., \& Hillman, N.H. (2015). A closer look at the trillion: Borrowing, repayment, and default at Iowa's community colleges. Washington, DC: Association of Community College Trustees.

Carnevale, A.P., Cheah, B., \& Hanson, A.R. (2015). The economic value of college majors. Washington, DC: Center on Education and the Workforce.

Carnevale, A.P., Rose, S.J., \& Cheah, B. (2011). The college payoff: Education, opportunities, lifetime earnings. Washington DC: Center on Education and the Workforce.

Chakrabarti, R., Haughwout, A., Lee, D., Scally, J., \& van der Klaauw, W. (2017, April). Press Briefing on Household debt, with Focus on Student Debt. New York, NY: Federal Reserve Bank of New York.

Charles, K.D., Sheaff, S., Woods, J., \& Downey, L. (2016). Decreasing your student loan cohort default rate: Leading a college-wide change initiative at Mohave Community College. Community College Journal of Research and Practice, 40(7), 597-606. 
Chen, X. \& Simone, S. (2016, September). Remedial Coursetaking at U.S. Public 2- and 4-Year Institutions: Scope, Experiences, and Outcomes. Washington, D.C.: National Center for Education Statistics.

Christman, D.E. (2000). Multiple realities: Characteristics of loan defaulters at a two-year public institution. Community College Review, 27, 16-32.

Clarke, P., Crawford, C., Steele, F., Vignoles, A. (2015). Revisiting fixed- and randomeffects models: some considerations for policy-relevant education research. Education Economics 23(3), 259-277.

Cohen, B.H. (2008). Explaining psychological statistics (3rd Edition). Hoboken, NJ: John Wiley \& Sons.

Cohen, A.M. (2001). Governmental policies affecting community colleges: A historical perspective. In: Townsend, B.K. \& Twombly, S.B. (Eds.) (2001). Community colleges: Policy in the future context. Westport, CT: Ablex.

Cohen, A.M. (1998). The shaping of American higher education: Emergence and growth of the contemporary system. San Francisco, CA: Jossey-Bass Publishers.

Cohen, J. (1992). A power primer. Psychological Bulletin, 112(1), 155-159.

Community College Research Center. (2014). What we know about developmental education outcomes. New York, NY: Community College Research Center. Retrieved from: https://ccrc.tc.columbia.edu/media/k2/attachments/what-weknow-about-developmental-education-outcomes.pdf

Cross, D. \& Olinsky, A. (1986, February). Student Loan Payers and Defaulters. Paper presented at the Annual Meeting of the Association for the Study of Higher Education, San Antonio, TX.

Creswell, J.W. (2009). Research Design: Qualitative, Quantitative, and Mixed Methods Approaches. Thousand Oaks, CA: Sage Publications.

Creswell, J.W. (2012). Educational research: Planning, conducting, and evaluating quantitative and qualitative research (4th Edition). Boston, MA: Pearson Education.

Creswell, J.W. (2013). Qualitative inquiry \& research design: Choosing among the five approaches. Thousands Oak, CA: Sage Publications. 
Cunningham, A.F. \& Kienzl, G.S. (2011). Delinquency: The untold story of student loan borrowing. Washington, DC: Institute for Higher Education Policy.

Deming, D.J., Goldin, C., \& Katz L.F. (2012). The for-profit postsecondary school sector: Nimble critters or agile predators? Journal of Economic Perspectives, 26(1), 139-164.

Dillon, E. \& Smiles, R.V. (2010). Lowering Student Loan Default Rates: What One Consortium of Historically Black Institutions Did to Succeed. Education Sector Reports.

Dougherty, K.J. \& Reddy, V. (2011). The Impacts of State Performance Funding Systems on Higher Education Institutions: Research Literature Review and Policy Recommendations. New York, NY: Community College Research Center.

Dowd, A.C. (2005). Data don't drive: Building a practitioner-driven culture of inquiry to assess community college performance. Lumina Foundation.

Dykeman, W. \& Wilford, A.B. (2015). “Kentucky” Encyclopedia Britannica Online. Retrieved from: https://www.britannica.com/place/Kentucky

Dyl, E.A. \& McGann, A.F. (1977). Discriminant analysis of student loan applications. Journal of Student Financial Aid, 7(3), 35-40.

Dynarski, M. (1994). Who defaults on student loans? Findings from the National Postsecondary Student Aid Study. Economics of Education Review, 13(1), 55-68.

Dynarski, S. (2015). An Economist's Perspective on Student Loans in the United States. CESifo Working Paper, No. 5579.

Eckel, P.D. \& King, J.E. (2004). An overview of higher education in the United States: Diversity, access, and the role of the marketplace. Washington, DC: American Council on Education.

Emmert, M.A. (1978). National Direct Student Loan default rates: A measure of administrative quality, or something else? Journal of Student Financial Aid, 8(3), 43-47.

Ethington, C.A., Thomas, S.L., \& Pike, G.R. (2002). Back to the basics: Regression as it should be. Higher Education: Handbook of Theory and Research.

Flint, T.A. (1994). The federal student loan default cohort: A case study. Journal of Student Financial Aid 24(1), 13-30. 
Flint, T.A. (1997). Predicting student loan defaults. The Journal of Higher Education 68(3), 322-354.

Galloway, F.J. \& Swail, W.S. (1999). Institutional Retention Strategies at Historically Black Colleges and Universities and Their Effects on Cohort Default Rates: 19871995. Washington, DC: Educational Policy Institute.

Gelman, A. \& Hill, J. (2007). Data analysis using regression and multilevel/hierarchical models. Cambridge, UK: Cambridge University Press.

Gigerenzer, G., Krauss, S., \& Vitouch, O. (2004). The null ritual: What you always wanted to know about significance testing but were afraid to ask. In Kaplan, D. (Ed.), The sage handbook of quantitative methodology for the social science (pp. 391-408). Thousand Oaks, CA: Sage Publications.

Gillen, A., Slingo, J. \& Zatynski, M. (2013). Degrees of value: Evaluating the return on the college investment. Washington, DC: American Institutes for Research.

Gillen, A. (2013, July). In Debt and In the Dark: It's Time for Better Information on Student Loan Defaults. Washington, DC: Education Sector. Washington, DC: The National Center for Public Policy and Higher Education.

Goodell, J.W. (2016). Do for-profit universities induce bad student loans? The Quarterly Review of Economics and Finance, 61, 173-184.

Gray, K.S. (1985). Can student loan default be forecast accurately? Journal of Student Financial Aid, 15(1), 31-41.

Greene, L.L. (1989). An economic analysis of student loan default. Educational Evaluation and Policy Analysis, 11(1), 61-68.

Gross, J.P.K. \& Hillman, N. (2014, March 21). “Student Loans II: How Much Default?” Inside Higher Ed. Retrieved from: https://www.insidehighered.com/views/2014/03/21/how-much-student-loan-debtand-default-appropriate-essay

Gross, J.P.K., Cekic, O., Hossler, D., \& Hillman, N. (2009). What matters in student loan default? A review of the research literature. Journal of Student Financial Aid, 39(1), 19-29. 
Hakim, S.R. \& Rashidian, M. (1995). Student loan default: Borrower characteristics, institutional practices, and the business cycle. Journal of Education Finance, 20(4), 449-466.

Harrison, M. (1995). Default in Guaranteed Student Loan Programs. Journal of Student Financial Aid, 25(2), 25-41.

Herr, E. \& Burt, L. (2005). Predicting student loan default for the University of Texas at Austin. Journal of Student Financial Aid, 35(2), 27-49.

Hillman, N. (2014a). College on credit: A multilevel analysis of student loan default. The Review of Higher Education, 37(2), 169-195.

Hillman, N. (2014b, October). Designing Better Ways to Regulate Colleges with Too Many Students who Default on Federal Loans. Scholar Strategy Network. Retrieved from: http://www.scholarsstrategynetwork.org/sites/default/files/ssn_basic_facts_hillma n_on_designing_a_better_cohort_default_rate_policy_3.pdf

Hillman, N.W. (2015a). Borrowing and repaying student loans. Journal of Student Financial Aid, 45(3), 35-48.

Hillman, N.W. (2015b). Cohort Default Rates: Predicting the probability of federal sanctions. Educational Policy, 29(4), 559-582.

Hillman, N. (2016, May 25). Why performance-based college funding doesn't work. The Century Foundation. Retrieved from: https://tcf.org/content/report/whyperformance-based-college-funding-doesnt-work/

Howard, R.D., McLaughlin, G.W., \& Knight, W.E. (2012). The Handbook of Institutional Research. San Francisco, CA: Jossey-Bass.

Ionescu, F. \& Ionescu, M. (2014). The interplay between student loans and credit card debt: Implications for default in the Great Recession. Washington, D.C.: Federal Reserve Board.

Ishitani, T.T. \& McKitrick, S.A. (2016). Are student loan default rates linked to institutional capacity? Journal of Student Financial Aid, 46(1), 17-37.

Jackson, B.A. \& Reynolds, J.R. (2013). The price of opportunity: Race, Student loan debt, and college achievement. Sociological Inquiry, 83(3), 335-368. 
Juszkiewicz, J. (2014). Community college students and federal student financial aid: A primer. Washington, DC: American Association of Community Colleges. Kentucky Community and Technical College System. (2016). KCTCS Fact Book. Versailles, KY: KCTCS Office of Research and Policy Analysis. Retrieved from: https://systemoffice.kctcs.edu/About/Institutional_Research

Kentucky Community and Technical College System. (2017a). Board of Regents.

Versailles, KY. Retrieved from:

http://systemoffice.kctcs.edu/en/Open_and_Responsible/Board_of_Regents.aspx

Kentucky Community and Technical College System. (2017b). Accreditation. Versailles, KY. Retrieved from: http://www.kctcs.edu/Our_Colleges/Accreditation

Kentucky Council on Postsecondary. (2016, September). Student loan default and repayment in Kentucky. Frankfort, KY: Kentucky Council on Postsecondary Education Office of Research and Policy Analysis.

Kesterman, F. (2006). Student borrowing in America: Metrics, demographics, default aversion strategies. Journal of Student Financial Aid, 36(1), 34-52.

King, J.B. Jr., McIntosh, A., Bell-Ellwanger, J. (2017). Developmental Education: Challenges and Strategies for Reform. Department of Education, 2017. Retrieved from: https://www2.ed.gov/about/offices/list/opepd/educationstrategies.pdf

Klor de Alva, J. \& Schneider, M. (2013). What's the value of an Associate's degree? The return on investment for graduates and taxpayers. Washington, DC: American Institutes for Research.

Knapp, L.G. \& Seaks, T.G. (1992). An analysis of the probability of default on federally guaranteed student loans. The Review of Economics and Statistics, 74(3), 404411.

Li, W. (2013). The Economics of Student Loan Borrowing and Repayment. Business Review, Q3, p. 1-12.

Lochner, L.J. \& Monge-Naranjo, A. (2014, January). Default and repayment among baccalaureate degree earners, Working Paper No. 2014-003. Chicago, IL: Economics Research Center. 
Looney, S.M. (2011, December). Cohort Default Rates in Context. Washington, DC: Institute for Higher Education Policy.

Ma, J. \& Baum, S. (2016). Trends in community colleges: Enrollment, prices, student debt, and completion. New York, NW: The College Board.

Maas, C.J. \& -Hox, J.J. (2005). Sufficient sample sizes for multilevel modeling. Methodology, 1(3), 86-92.

McCormick, J.L. (1987). The default rate factor: Who is really at fault? Journal of Student Financial Aid 17(1), 31-36.

McKibben, B., La Rocque, M. \& Cochrane, D. (2014). Protecting colleges and students: Community college strategies to prevent default. Oakland, CA: The Institute for College Access and Success.

McKinney, L., \& Burridge, A.B. (2015). Helping or Hindering? The Effects of Loans on Community College Persistence. Research in Higher Education, 56(4), 299-324.

McKinney, L., Gross, J.P.K., \& Burridge, A.B. (2014). How community college can help prevent financial hardship among student borrowers. Community College Journal of Research and Practice, 38, 270-274.

McKinney, L., Gross, J.P.K., \& Inge, B. (2014, November). Understanding federal loan borrowing, repayment, and default among community college students. Paper presented at the Annual Meeting of the Association for the Study of Higher Education, Washington, DC.

McKinney, L., Novak, H., \& Hagedorn, L.S. (2016). Borrowing among academically underprepared students: Facilitating success or perpetuating inequity at the community college? Bryan, TX: Greater Texas Foundation.

McKinney, L., Mukherjee, M., Wade, J., Shefman, P., Breed, R. (2015). Community college students' assessments of the costs and benefits to borrowing to finance higher education. Community College Review, 43(4), 329-354.

Myers, G. \& Siera, S. (1980). Development and validation of discriminant analysis models for student loan defaultees and non-defaultees. Journal of Student Financial Aid, 10(1), 9-17.

Merisotis, J.P. (1988). Default trends in major postsecondary sectors. Journal of Student Financial Aid, 18(1), 18-28. 
Mezza, A. \& Sommer, K. (2015). Predictors of Student Loan Delinquency: The Role of Borrower Credit Information. Washington, DC: Federal Reserve Board.

Monteverde, K. (2000). Managing student loan default risk: Evidence from a privately guaranteed portfolio. Research in Higher Education, 41(2), 331-352.

Mullen, A. (2010). Degrees of inequality: Culture, class, and gender in American higher education. Baltimore, MD: John Hopkins University Press.

National Association of Financial Aid Administrators. (2008). NASFAA Summary of the Higher Education Opportunity Act. Washington, DC: National Association of Student Financial Aid Administrators. Retrieved from: https://www.nasfaa.org/newsitem/2374/NASFAA_Summary_of_the_Higher_Education_Opportunity_Act_HE OA

National Association of Financial Aid Administrators. (2013). Reimagining Financial Aid to Improve Student Access and Outcomes. Washington, DC: National Association of Student Financial Aid Administrators. Retrieved from: https://www.nasfaa.org/uploads/documents/ektron/67439aeb-419d-4e9c-90354278d0bbed61/d19119911e864c39abb555e99f130d122.pdf

National Association of Financial Aid Administrators. (2014). NASFAA Task Force Report: Consumer Information. Washington, DC: National Association of Student Financial Aid Administrators. Retrieved from: https://www.nasfaa.org/uploads/documents/ektron/67439aeb-419d-4e9c-90354278d0bbed61/d19119911e864c39abb555e99f130d122.pdf

National Center for Education Statistics. (2015). Fast Facts: Enrollment. Retrieved from: https://nces.ed.gov/fastfacts/display.asp?id=98

National Center for Education Statistics. (2016). Undergraduate Retention and Graduation Rates. https://nces.ed.gov/programs/coe/indicator_ctr.asp National Center for Education Statistics. (2017). About Us. https://ies.ed.gov/aboutus/ National Center for Education Statistics. (2017). College Navigator. https://ies.ed.gov/ New America Foundation. (2014). The case for payroll withholding: Preventing student loan defaults with automatic income-based repayment. Washington DC: New America. 
Niehaus, E., Campbell, C. \& Inkelas, K.K. (2014). HLM Behind the Curtain: Unveiling decisions behind the use and interpretation of HLM in higher education research. Research in Higher Education, 55, p. 101-122.

Oreopoulos, P. \& Petronijevic, U. (2013). Making college worth it: A review of the returns to higher education. The Future of Children, 23(1).

Osborne, J. (2013). Best practices in data cleaning. Thousand Oaks, CA: Sage Publications.

Osborne, J. (2014). Best practices in logistic regression. Thousand Oaks, CA: Sage Publications.

Osborne, J.W. (2016). Regression and linear modeling: Best practices and modern methods. Thousand Oaks, CA: Sage Publications.

Paulsen, M. (2001). In Pausen, M.B. \& Smart, J.C. (2001). The finance of higher education: Theory, research, and practice. Agathon Press: New York, N.Y.

Podgursky, M., Ehlert, M., Monroe, R., \& Watson, D. (2002). Student loan defaults and enrollment persistence. Journal of Student Financial Aid, 32(3), 27-42.

Price, D.V. (2004). Borrowing inequality: Race, class, and student loans. Boulder, CO: Lynne Rienner Publishers, Inc.

Raudenbush, S.W. \& Bryk, A.S. (2002). Hierarchical Linear Models: Applications and data analysis methods. Thousand Oaks, CA: Sage Publications.

Raudenbush, S.W., Bryk, A.S., Cheong, Y.F., Congdon, R.T. Jr., du Toit, M. (2011).

HLM7: Hierarchical linear and nonlinear modeling. Lincolnwood, IL: Scientific Software International.

Raudenbush, S.W., Bryk, A.S, \& Congdon, R. (2013). HLM 7.01 for Windows [Computer software]. Skokie, IL: Scientific Software International, Inc.

Robson, K. \& Pevalin, D. (2016). Multilevel modeling in plain language. Los Angeles, CA: Sage Publications.

Ryan, L.D. (1993). California State University Loan Defaulters' Characteristics. Journal of Student Financial Aid, 23(3), 29-42.

Scott-Clayton, J. (2017). Undergraduate Financial Aid in the United States. Cambridge, MA: American Academy of Arts and Sciences. 
Scott-Clayton, J. \& Li, J. (2016, October 20). Black-white disparity in student loan debt more than triples after graduation. Washington, DC: Brookings Institution.

Shadish, W.R., Cook, T.D., \& Campbell, D.T. (2002). Experimental and quasiexperimental designs for generalized causal inference. Boston, MA, US: Houghton, Mifflin and Company.

Shmueli, G. (2010). To explain or to predict? Statistical Science, 25(3), 289-310.

Seifert, C.F. \& Wordern, L. (2004). Two studies assessing the effectiveness of early intervention on the default behavior of student loan borrowers. Journal of Student Financial Aid, 34(3), 41-52.

Smith, D.G. (2015). Diversity's promise for higher education: Making it work. (2nd Ed.). Baltimore, MD: The John Hopkins University Press.

Snijders, A.B. (2005). Power and sample size in multilevel models. In B.S. Everitt and D.C. Howell (Eds). Encyclopedia of Statistics in Behavioral Science, p. 15701573. Chicester: Wiley, 2005.

Snijders, T.A.B. \& Bosker, R.J. (2012). Multilevel Analysis: An introduction to basic and advanced multilevel modeling. $2^{\text {nd }}$ Ed. Thousand Oaks, CA: Sage Publications.

Steinbaum, M. \& Vaghul, K. (2016, February 17). How the student debt crisis affects African Americans and Latinos. Washington, DC: Washington Center for Equitable Growth. "Mapping Student Debt” Blog Series

Steiner, M. \& Barone, S. (2014, May). Detecting early signs of default risk at Austin Community College. Austin, TX: Texas Guaranteed Research and Analytical Services.

Steiner, M. \& Teszler, N. (2005, January). Multivariate Analysis of Student Loan Defaulters at Texas A\&M University. Austin, TX: Texas Guaranteed Research and Analytical Services.

Steiner, M. \& Tym, C. (2005, March). Multivariate analysis of student loan defaulters at the University of South Florida. Austin, TX: Texas Guaranteed Research and Analytical Services.

Stevens, J. (2007). Applied multivariate statistics for the social sciences (3rd ed.). Mahwah, NJ: Lawrence Erlbaum Associates. 
Stockham, D.H. \& Hesseldenz, J.S. (1979). National direct student loan defaults: The role of personality data. Research in Higher Education, 10(3), 195-205.

Thobe, T.M. \& DeLuca, B.M. (1997). A model for predicting Perkins loan defaulters. Journal of Student Financial Aid, 27(1), 31-43.

TICAS. (2016, June). States of Denial: Where Community College Students Lack Access to Federal Student Loans. Oakland, CA: The Institute for College Access and Success. Retrieved from: http://ticas.org/sites/default/files/pub_files/states_of_denial.pdf

TICAS. (2013, April). Using a Student Default Risk Index (SDRI) to Improve Institutional Accountability and Reward Colleges. Oakland, CA: The Institute for College Access and Success.

Tollefson, T.A., Garrett, R.L., Ingram, W.G. (1999). Fifty State Systems of Community Colleges: Mission, Governance, Funding, and Accountability. Johnson City, TN: The Overmountain Press.

United States Bureau of Labor Statistics. (2017). https://www.bls.gov/

United States Census Bureau. (2016). QuickFacts: Kentucky. Retrieved from http://www.census.gov/quickfacts/table/PST045215/21

United States Census Bureau. (2015). 2015 American Community Survey 1-Year Estimates.

United States Census Bureau. (2017). About the Bureau. Retrieved from: https://www.census.gov/about.html

United States Department of Education. (2017). Understanding Delinquency and Default. Retrieved from: https://studentaid.ed.gov/sa/repay-loans/default United States Department of Education. (2016a). Official Cohort Default Rates FY 2013. Washington, DC: Department of Education. Retrieved from: https://studentaid.ed.gov/sa/types/loans/federal-vs-private United States Department of Education. (2016b). How to Repay Your Loans: Understanding Default. Washington, DC: U.S. Department of Education Office of Federal Student Aid. Retrieved from: https://studentaid.ed.gov/sa/repayloans/default 
United States Department of Education. (2016c). Cohort Default Rate Guide.

Washington, D.C.: U.S. Department of Education Office of Federal Student Aid.

Retrieved from: https://ifap.ed.gov/DefaultManagement/CDRGuideMaster.html

United States Department of Education. (2016d). Direct Loans Entering Default.

Washington DC: U.S. Department of Education Office of Federal Student Aid.

United States Department of Education. (2016e). Default Prevention and Management: A

Plan for Student and School Success. Washington DC: U.S. Department of

Education Office of Federal Student Aid. Retrieved from:

https://ifap.ed.gov/dpcletters/attachments/GEN0514Attach.pdf

United States Department of Education. (2016f). FY 2013 3-Year Official Cohort Default

Rates by State/Territory. Washington DC: U.S. Department of Education Office

of Federal Student Aid. Retrieved from:

https://www2.ed.gov/offices/OSFAP/defaultmanagement/staterates.pdf

United States Department of Education. (2016g). Comparison of FY 2013 Official

National Cohort Default Rates to Prior Two Official Cohort Default Rates.

Washington, DC: Department of Education.

United States Department of Education. (2014, September 23). Adjustment of

Calculation of Official Three Year Cohort Default Rates for Institutions Subject

to Potential Loss of Eligibility. Retrieved from:

https://ifap.ed.gov/eannouncements/092314AdjustmentofCalculationofOfc3YrCD

RforInstitutSubtoPotentialLossofElig.html

United States Department of Education. (2006). A test of leadership: Charting the future

of U.S. higher education. Washington, DC.

United States General Accounting Office. (1995). Student Loan Defaults: Department of

Education Limitations in Sanctioning Problem Schools. Washington, DC: United

States General Accounting Office. http://www.gao.gov/assets/230/221347.pdf

United States General Accounting Office. (1988, January). Guaranteed Student Loans:

Potential Default and Cost Reduction Options. Washington, DC: United States

General Accounting Office.

Vogt, W.P., Gardner, D.C. \& Haeffele, L.M. (2012). When to use what research design.

New York, NY: The Guilford Press. 
Vogt, W.P., Vogt, E.R., Gardner, D.C. \& Haeffele, L.M. (2014). Selecting the right analyses for your data: Quantitative, qualitative, and mixed methods. New York, NY: The Guilford Press.

Volkwein, J.F. \& Szelest, B.P. (1995). Individual and campus characteristics associated with student loan default. Research in Higher Education, 36(1), 41-72.

Volkwein, J.F., Szelest, B.P., Cabrera, A.F. \& Napierski-Prancl, M.R. (1998). Factors associated with student loan default among different racial and ethnic groups. The Journal of Higher Education, 69(2), 206-237.

Wagner, W.E. (2017). Using IBM SPSS Statistics for Research Methods and Social Science Statistics. Thousand Oaks, CA: Sage Publications Ltd.

Webber, K.L. \& Rogers, S.L. (2014). Student loan default: Do characteristics of fouryear institutions contribute to the puzzle? Journal of Student Financial Aid, 44(2), 99-124.

Weissman, E., Cerna, O., Cullinan, D., \& Baldiga, A. (2017). Aligning Aid with Enrollment: Interim Findings on Aid Like a Paycheck. New York, NY: MDRC.

Wiederspan, M. (2015). Denying Loan Access: The Student-Level Consequences When Community Colleges Opt out of the Stafford Loan Program. Ann Arbor, MI: Center for the Study of Higher and Postsecondary Education.

Wilms, W.W., Moore, R.W., \& Bolus, R.E. (1987). Whose fault is default? A study of the impact of student characteristics and institutional practices on Guaranteed Student Loan default rates in California. Educational Evaluation and Policy Analysis 9(1), 41-54.

Woltman, H., Feldstain, A., MacKay, J.C., \& Rocchi, M. (2012). An introduction to hierarchical linear modeling. Tutorials in Quantitative Methods for Psychology $8(1), 52-69$.

Woo, J.H. (2002). Factors affecting the probability of default: Student loans in California. Journal of Student Financial Aid 32(2), 5-23.

Zalaznick, M. (2016). Advocates fear racial disparities in student loan defaults. University Business. Retrieved from: https://www.universitybusiness.com/article/advocates-fear-racial-disparitiesstudent-loan-defaults 
Zumeta, W. Breneman, D.W., Callan, P.M., Finney, J.E. (2012). Financing American higher education in the era of globalization. Cambridge, MA: Harvard University Press. 


\section{APPENDIX}

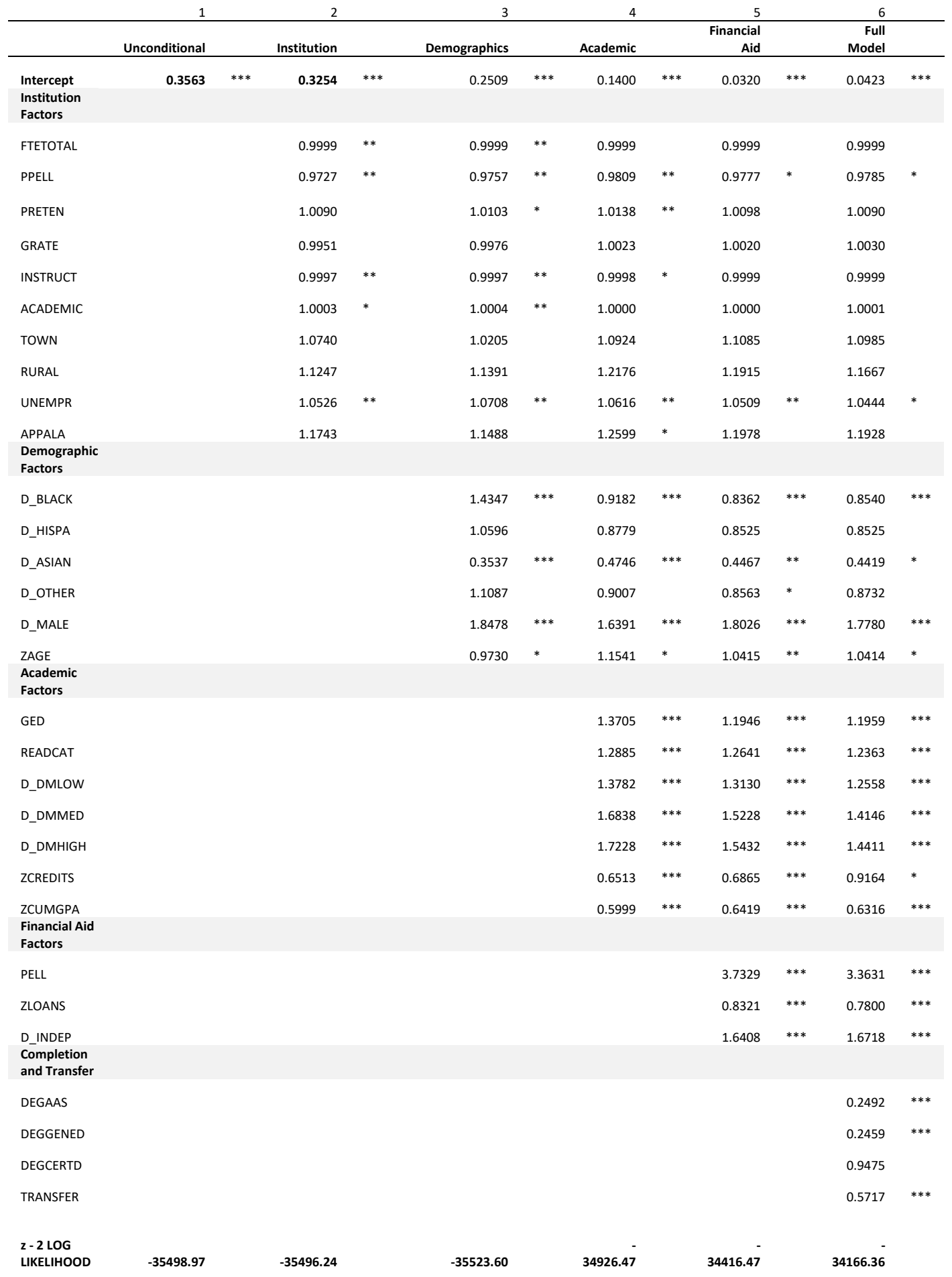


300 North Main Street

Versailles, KY 40383

Telephone (859) 256-3100

Website: ketcs.edu

$4 / 20 / 2017$

Brittany Inge

Jefferson Community \& Technical College

109 East Broadway

Louisville, KY 40202

RE: Factors Associated with Student Loan Default among Borrowers in a Statewide Community College System

Dear Brittany:

After careful consideration of your application to the KCTCS Human Subjects Review Board, I have determined that you are eligible for exemption from federal regulations regarding the protection of human subjects based on your research using a procedure that meets the exempt review criteria section 7 (4).

Thank you for your cooperation in meeting the federal requirements for conducting research that utilizes human subjects. We appreciate your notification to this board and we will keep your information on file.

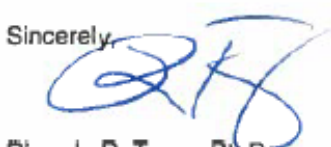

Rhonda R. Tracy, Phte.

KCTCS Chancellor

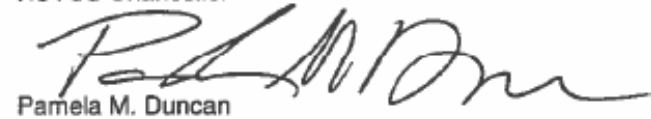

Associate General Counse

Chair, KCTCS Human Subjects Review Board

cc: Alicia Crouch

Vice Chancellor of Research \& Policy Analysis

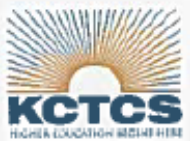




\title{
CURRICULUM VITA
}

\author{
Brittany Inge \\ 2400 Sherry Road \\ Louisville, Kentucky 40217 \\ 502-489-1275 \\ brittany.inge@kctcs.edu
}

\section{EDUCATION}

PhD, Educational Leadership and Organizational Development (2017)

University of Louisville

Postsecondary Administration

Dissertation: "Factors Associated with Federal Student Loan Default Among

Borrowers in a Statewide System of Community and Technical Colleges"

Master of Arts, Higher Education Administration (2012)

University of Louisville

Bachelor of Arts, History (2010)

University of Louisville

\section{PROFESSIONAL EXPERIENCE}

Coordinator of Institutional Research \& Effectiveness (August 2016 to Present) Research Assistant (March 2013 to August 2016)

Jefferson Community and Technical College

- Retrieves institutional data from the Kentucky Community and Technical College System (KCTCS) Decision Support System (DSS) Oracle Database. Uses Microsoft Excel, Access, and SPSS software to manipulate and analyze data. Coordinates data collection, analysis, and reporting for institutional programs and projects.

- Responds to ad hoc data requests from administrators, faculty, and staff related to student enrollment, retention, success, and other institutional metrics.

- Manages and prepares institutional reports to ensure compliance with the Southern Association of Colleges and Schools Commission on Colleges (SACSCOC) Substantive Change policy. Prepares prospectus reports for new offsite locations and programs. 
- Serves as a liaison to various institution-wide committees and presents data to inform decision-making for institutional initiatives, including the Leadership Cabinet, Board of Directors, Title III Steering Committee, Strategic Enrollment Management Team, Student and Academic Affairs Leadership Team, and the Default Management Team.

Gift Recording Specialist (July 2010 to March 2013)

University of Louisville

- Researched and recorded philanthropic giving data into the University of Louisville Development/Alumni database (Ellucian Advance). Used spreadsheet and database software to manage giving data. Prepared a daily financial report for distribution to the Vice President for University Advancement and Development Officers.

Research Assistant (March 2007 to July 2010)

REACH of Louisville

- Assisted with the coordination and administration of the Kentucky Incentives Prevention (KIP) Survey, a survey administered to middle and high school students across Kentucky. Assisted with program evaluation data collection and analysis: conducted and transcribed interviews, assisted with survey administration, utilized SPSS to perform statistical analysis, and created prepared reports for external agencies. Researched and composed literature reviews to provide contextual background for senior evaluation research staff.

\section{TEACHING EXPERIENCE}

University of Louisville

Teaching Assistant - Spring 2017

Graduate Courses:

Educational Resource Management in Postsecondary Education Diversity in Higher Education

Jefferson Community and Technical College

Instructor - Fall 2017

Undergraduate Course:

First Year Experience

\section{RESEARCH AND SCHOLARSHIP}

Inge, B., Fowler, P., \& Gross, J. P. (2015). Preparing for HEA Reauthorization: Recommendations for Practitioners. Journal of Student Financial Aid. 45(3). 
Gross, J.P.K., Zerquera, D., Inge, B., \& Berry, M. (2014). Latino Associate Degree Completion: Effects of Financial Aid Over Time. Journal of Hispanic Higher Education 13(3), 177-190.

Gross, J.P.K. \& Inge, B. (2013). A Shifting Landscape: A History of the National Association of Student Financial Aid Administrators, 2006-2011. Washington, DC: National Association of Student Financial Aid Administrators.

Smith, P., Pennington, M., Illback, R. \& Inge, B. (2010). Economic Evaluation of KIDS NOW: Estimating Costs and Benefits for Kentucky's Early Childhood Initiative for FY 2008." REACH Evaluation.

\section{CONFERENCE PAPERS AND PRESENTATIONS}

Inge, B. (2016). Deconstructing Default: Using Institutional Data to Identify Borrowers At Risk for Loan Default. Presented at Kentucky Association of Collegiate Registrars and Admissions Officers Conference, Owensboro, Kentucky.

Inge, B. (2015). Deconstructing Default: Using Institutional Data to Facilitate Targeted Default Prevention Strategies. Presented at Kentucky Community and Technical College System New Horizons Conference, Covington, Kentucky.

Sanders, K. \& Inge, B. (2015). Social Justice Identity Development \& Academic Advising: Advocates \& Allies. Presented at the University of Louisville College of Education and Human Development Spring Research Conference.

Christensen, C. \& Inge, B. (2015). Effects of Gender and Degree Expectation on Constructs of Math Achievement. Presented at the University of Louisville College of Education and Human Development Spring Research Conference.

Gross, J.P.K., McKinney, L., \& Inge, B. (2015). Understanding Loan Default among Community College Students. Paper presented at the 2014 ASHE Annual Conference, Washington DC.

\section{$\underline{\text { AWARDS }}$}

Achieving the Dream and Association for Institutional Research Data and Decisions Academy Scholarship Recipient, 2017

Southern Association for Colleges and Schools Commission on Colleges Travel Grant Recipient, 2016 